\title{
HISTORICAL CONTEXTS FOR THE EMERGENCE AND TRANSMISSION OF BUDDHISM WITHIN SOUTH ASIA
}

Interpreting the past is a critical concern for Buddhist communities, despite stereotypes that associate mystical disregard of history with Buddhism and other South Asian religious traditons. Flexible narratives about the past have shaped Buddhist identities by providing models of meritorious action and have contributed to expansion beyond northeastern India by establishing locative links to the Buddha's presence. Stories about the Buddha's life and the formation of the sangha connect his birth, awakening, teachings, miraculous performances, and recruitment of followers to specific places and temporal frameworks. Hagiographical accounts of the rediscovery of the "True Dharma" (saddharma) taught by previous Buddhas in earlier ages and the turning of the "Wheel of Dharma" (dharmacakra) in the present auspicious age (bhadrakalpa) may seem ahistorical, since the accomplishments attributed to Sākyamuni Buddha are not particular to his own historical circumstances. ${ }^{1}$ Although restrictive views of history as an objective chronicle of past events would deny any value to traditional identifications of links between causes in past lives and consequences in present or future lifetimes in Buddhist literary sources, maximalist conceptions of history as an effort to understand "how human actions are significant and have a notable impact on our world" (Nattier 1991: 139) provide more scope for understanding why interpretation of past actions was important for present concerns.

The aim of this chapter is to clarify geographical and chronological contexts for patterns and processes in the formation of Buddhism in ancient and early medieval South Asia and its transregional expansion

${ }^{1}$ For literary traditions about Buddhas of the past, auspicious present aeon (bhadrakalpa), and the future, see Nattier, Jan. 1991. Once Upon a Future Time: Studies in a Buddhist prophecy of decline. Berkeley, Calif: Asian Humanities Press, 19-26; Strong, John. 2001. The Buddha: A short biography. Oxford: Oneworld, 20-21, Table 1.1 and Strong 2004a: 25-49. Nattier emphasizes that “... it is a central contention of virtually all schools of Buddhism that the Buddha's experience is by definition repeatable and is accessible (at least in theory) to all living beings" (1991: 7-8). 
outside of the Indian subcontinent, particularly in the northwesten frontiers of areas of modern Pakistan and Afghanistan. Beginning with the period of the historical Buddha's lifetime in the fifth century $\mathrm{BCE}$, the chronological range of this overview extends to the late first millennium CE. A detailed macrohistory of South Asian Buddhism is beyond the intended scope, but significant junctures between political, economic, and social networks for Buddhist mobility are emphasized in an effort to identify factors and catalysts for cross-cultural transmission. An historical-critical approach to literary, epigraphical, numismatic, and archaeological sources elucidates regional variation and different actors, features, stages, and levels of Buddhist movement, which fluctuated considerably with shifting political and commercial alignments. This effort to investigate the role of trade exchanges, intercultural encounters, and inter- and intrareligious relationships in the establishment, expansion, and decline of Buddhist institutions spurs several questions, which are addressed throughout the chapter. What was at stake for Buddhist communities in formulating stories about the Buddha's present and past lives, describing the formation of the saigha, and locating events in regional settings? How did interactions with other groups, including competing renouncer movements, Brahmins, and exogenous migrants, shape Buddhist perspectives and practices? What do available sources from within and outside of Buddhist traditions reveal about the impact of social and economic changes on Buddhist institutions? Which roles did Buddhist models of exchange, patronage, and supramundane power play in commerce and sociopolitical legitimation?

In the following subsections, which are structured diachronically and regionally, I explore the formation and transmission of Buddhist ideologies and institutions in changing historical and cultural environments, since Buddhist traditions did not originate autonomously or remain static.

A. Initial Phases of the Establishment of Buddhist Communities in Early India

B. Legacy of the Mauryans: Aśoka as Dharmarāja

C. Migrations, Material Exchanges, and Intercultural Interactions in Northwestern Contact Zones

D. Saka Migrants and Mediators between Central Asia and South Asia

E. Dynamics of Mobility during the Kuṣāna Period 
F. Shifting Networks of Political Power and Institutional Patronage during the Gupta Period

G. Cross-Cultural Transmission between South Asia and Central Asia, ca. $500-100 \mathrm{CE}$

\section{Initial Phases of the Establishment of Buddhist Communities in Early India}

Hagiographic accounts of the Buddha's religious biography combine legendary narratives with information about the religious, social, economic, and political climate of his time, as viewed through later literary lenses. ${ }^{2}$ Rather than separating historical fact from literary fiction in order to demythologize the life story of the Buddha, the analysis of Buddhist literary sources postdating the lifetime of the Buddha and archaeological findings presented here is intended to establish basic chronological and geographical parameters and to undertand the contexts in which he and his followers flourished. Although the historical Buddha's precise dates are difficult to pinpoint, situating his lifetime in the fifth century BCE has widespread implications for South Asian history as well as religious and intellectual traditions during a period of dynamic social and cultural change.

Scholarly consensus on Saakyamuni Buddha's date, which is in fact the earliest historical date for building a relative chronology of late Vedic religions and ancient Indian political dynasties, has recently shifted in favor of a "short chronology" from a "long chronology" in response to a 1988 symposium in Göttingen and the multivolume publication of proceedings edited by Heinz Bechert. ${ }^{3}$ Although a "Nirvāna era" beginning with Śākyamuni's parinirvāna in 543 BCE is attested

${ }^{2}$ Strong 2001 provides a useful overview of hagiographical traditions for the life (and previous lives) of the Buddha according to various literary sources. Strong's stated goal is to portray the "Buddha of story" rather than the "Buddha of history" since traditional legends "... are certainly more plentiful, more interesting, and more revelatory of the ongoing concerns of Buddhists" (2001: 2). Historicist approaches privileging Pāli and Sanskrit literary sources over vernacular biographies of the Buddha are criticized by Hallisey, Charles. 1995. "Roads Taken and Not Taken in the Study of Theravāda Buddhism.” In Lopez 1995b: 31-61 (reprinted in Derris, Karen, and Natalie Gummer, eds. 2007. Defining Buddhism(s): A reader. London: Equinox Pub.).

${ }_{3}$ Bechert, Heinz, ed. 1991-1997. The Dating of the Historical Buddha = Die Datierung des historischen Buddha. 3 vols. Göttingen: Vandenhoeck \& Ruprecht. 
in Pāli vamsa literature, Bechert observes that “...there is no reliable second source to corroborate the validity of this chronology" (1989: 97). ${ }^{4}$ A "corrected long chronology" places the end of the Buddha's lifetime in ca. $486 \mathrm{BCE}$ by adjusting the date for the parinirvanna 218 years before the Mauryan ruler Aśoka was consecrated in ca. 270-268 BCE. ${ }^{5}$ However, literary sources outside of the Pāli tradition support a "short chronology" for the parinirvanna only one century before Aśoka's consecration, therefore corresponding to ca. 370 BCE. ${ }^{6}$ The suspiciously round number (100) probably indicates an approximate rather than absolute date, so an "adjusted short chronology" of the Buddha's death around 400 BCE is now widely favored. ${ }^{7}$ This somewhat arbitrary date avoids a problematic link between the beginning of Aśoka's rule and a second Buddhist communal recitation (sangiti) or "council" at Vaiśâlī, which was also supposed to have taken place a century after the parinirvanna but is not as clearly linked with Aśoka as later councils. ${ }^{8}$ The issue of determining the date of the historical

${ }^{4}$ Bechert, Heinz. 1989. "The Problem of the Determination of the Date of the Historical Buddha." Wiener Zeitschrift für die Kunde Südasiens 33, 93-120. Lamotte (1988 [1958]: 13) discusses internal contradictions within the Pāli chronicles (Dipavamsa 6.1.19-20, Mahāvamsa 5.21) and commentaries (Samantapāsādikā, Atthasālinī).

${ }^{5}$ As detailed in the following subsection of this chapter, Aśoka's 13th Major Rock Edict provides a firm synchronism between the reign of Aśoka and five contemporary Hellenistic rulers in ca. 255 BCE.

${ }^{6}$ Evidence for a "short chronology" of the Buddha's parinirvānā 100 years before Aśoka's consecration in Dīpavamsa 1.24-26 and 5.55-59 supports Bechert's hypothesis that the long chronology" of 218 years was a later development (1989: 104 ff., 1991: 329-343). The earliest attested link between the Buddha's parinirvāna and Aśoka's reign a century later occurs in an avadāna set during the time of Aśoka "a century after the Blessed Buddha achieved parinirvāna" (vașaśada parinurvude budhe bhagavade) in a first century CE Kharosthī manuscript (British Library fragment 4.6 recto).

7 Prebish, Charles. 2008. "Cooking the Buddhist Books: The implications of the new dating of the Buddha for the history of early Indian Buddhism." Journal of Buddhist Ethics 15 observes that "... most participants [in the Göttingen symposium] suggested that the Buddha died within approximately a few decades on either side of 400 BCE" (1).

${ }^{8}$ Prebish examines implications of the "short chronology" for the dating of early councils at Rājagraha, Vaiśālī, and Pātaliputra, concluding that the Vaišálī council occured 37 years before Aśoka's coronation in 268 BCE, followed shortly by a "noncanonical" council at Pātaliputra marking the beginning of Buddhist sectarianism and another "canonical" council in Pātaliputra (attested only in Pāli sources) 18 years later (ca. 250 BCE). Prebish's argument that “... we should use all the sources available to us, and not just those that affirm a hypothesis that is convenient to our suppositions and anticipated expectations" (2008: 14-15) implies that conflicting sources should be accepted in order to construct a hybrid chronology for the date of the Buddha's parinirvāna. 
Buddha is also intertwined with traditional Jain dates for the nirvāna of Mahāvira (alleged to be a Jain contemporary of Saakyamuni) in 528 or 510 BCE. ${ }^{9}$ If we follow a short chronology for the historical Buddha's parinirvāna between ca. 400 and ca. 370 BCE, his lifespan of 80 years began in the early-mid fifth century BCE.

Table 2.1: Proposed dates for the Historical Buddha

\begin{tabular}{|c|c|c|}
\hline & Birth & Parinirvāṇa \\
\hline $\begin{array}{l}\text { Long Chronology } \\
\text { (Nirvāṇa Era) }\end{array}$ & 623 & $543 \mathrm{BCE}$ \\
\hline Corrected Long Chronology & 566 & $486 \mathrm{BCE}^{10}$ \\
\hline Adjusted Short Chronology & ca. 480 & $400 \mathrm{BCE}$ \\
\hline Short Chronology & ca. 450 & $370 \mathrm{BCE}^{11}$ \\
\hline
\end{tabular}

In addition to situating the historical Buddha's lifetime in a relatively specific time-frame between the middle of the fifth century and the beginning of the fourth century BCE, it is also possible to locate hagiographical events memorialized in Buddhist literature, inscriptions, monuments, and art in a geographical network of sacred sites. For example, an inscription of Aśoka marks the location where Māyā gave birth to Siddhārtha Gautama in a forest near the village of Lumbinī in southern Nepal:

The King, Beloved of the gods, of Loving Regard, when he had been anointed twenty years, came in person and worshiped, because the Buddha Sākyamuni was born here. He had constructed walls inlaid with stone (?) and had erected [this] stone pillar, because [i.e., to proclaim that] the Lord was born here. The village of Lummini was made exempt from taxation and [subject to paying only] one-eighth share [of its produce]. ${ }^{12}$

9 Śvetāmbara and Digambara dates for Mahāvīra's nirvāna conflict with Hemacandra's report of a time-span of 155 years before the reign of Candragupta, who began ruling after the Indian expedition of Alexander of Macedon between 327-5 BCE (Bechert 1989: 98-101).

${ }_{10} 218$ years before Aśoka's coronation in ca. 370-368 BCE.

11100 years before Aśoka's coronation.

12 Translated by Salomon 1998a: 264 (Appendix, selection 1: Rummindeì Minor Pillar Edict of Aśoka; see Falk 2006: 177-180 for further references and a discussion of silavagadabhīca or $-c a$, which he translates as "stone railing" instead of "walls inlaid with stone"). 
The epigraphic evidence of Aśoka's commemoration of a visit to the Buddha's birthplace at Lumbini confirms the localization of pilgrimage practices connected with this event by the middle of the third century BCE. The location of Kapilavastu, where Siddhārtha was raised by his aunt Mahāprajāpati as the son of Suddhodana, a chief of the Saakya clan, remains controversial. ${ }^{13}$ An early set of four sites placing the awakening at Bodh Gaya, initial teaching at Sarnath, and parinirvāna at Kuśinagara were later expanded to a list of eight sites, each with their own narrative cycles. ${ }^{14}$ Noting that the hagiography of the Buddha grew in tandem with the proliferation of Buddhist pilgrimage places, John Strong remarks: “...'where’ something happened is as significant as 'what' happened there" (2001: 5). Locative connections reinforce claims to antiquity of oral discourses said to have been spoken by the Buddha, doctrinal principles and monastic rules linked with early recitations, and pilgrimage and ritual centers. While Jonathan Z. Smith identifies the promotion of a "locative, imperial worldview" with "scribal elites who had a deep vested interest in restricting mobility and valuing place" (1978: 293), ${ }^{15}$ Buddhist efforts to localize hagiographic events in northeastern India and the Terai region of modern Nepal did not inhibit or restrict mobility.

Having situated the historical Buddha in northeastern India, what can be said about the society in which he lived and taught? Portrayals of Siddhārtha as a royal prince indicate that he was to be viewed as an archetypal Kșatriya scion in the traditional socio-religious hierarchy. However, fifth-fourth century BCE social contexts are difficult to reconstruct because Buddhist textual sources from periods later than the time of the historical Buddha tend to reflect their own contemporary social mores. ${ }^{16}$ Non-Buddhist traditions prescribing rigid stratification

${ }^{13}$ The sites of Gotihawa and Pipri near Lumbini have been excavated and the surrounding area has been surveyed by Verardi, Giovanni. 2007. Excavations at Gotihawa and Pipri, Kapilbastu District, Nepal. Rome: IsIAO.

14 Strong 2001: 6.

${ }^{15}$ For further theoretical and comparative perspectives on the locativization of religious geography, see Smith, Jonathan Z. 1987. To Take Place: Toward Theory in Ritual. Chicago: University of Chicago, and essays on "Topography of the Sacred" and "Here, There, and Everywhere" in Smith, Jonathan Z. 2004. Relating religion: essays in the study of religion. Chicago: University of Chicago Press, 101-116, 323-349.

${ }_{16}$ This distinction is not always maintained in works dealing with the social history of early Buddhism, including Bailey and Mabbett 2003 (especially chapters 2 and 5), Chakravarti, Uma. 1987. The Social Dimensions of Early Buddhism. Delhi: Oxford University Press, and Fick, Richard. 1897. Die sociale gliederung im nordöstlichen Indien 
among the four varnas (Brahmins, Kṣatriyas, Vaiśyas, and Sūdras) are not descriptive of social realities, but tend to reflect normative models and ideals. ${ }^{17}$ Buddhist literary texts consistently reflect these normative distinctions between Brahmins, Kṣatriyas, and other wealthy householders (often termed grhapatis) and groups of laborers, servants, and the poor with status largely determined by birth. ${ }^{18}$ Rather than challenging social and economic structures, Buddhist arguments against alleged Brahminical claims to purity valorize the superiority of ethical purity over ritual action. ${ }^{19}$ Didactic verses collected in the "Brāhmana Varga" of widely transmitted Dharmapada/Udānavarga collections clearly illustrate this critique, ${ }^{20}$ which is expressed in the first verse of a Kharoșthi manuscript of the Dharmapada from Khotan:

One does not become a Brahmin by matted dreadlocks, clan, or birth; but having expelled small and large wrongs in every way, an expeller of wrongs is someone called a Brahmin. ${ }^{21}$

$z u$ Buddha's zeit. Kiel: C.F. Haeseler (translated by Shrishirkumar Maitra, The Social Organization in North-East India in Buddha's Time. University of Calcutta, Calcutta: 1920, reprint, Varanasi: 1972). Wagle, N. K. 1966. Society at the time of the Buddha. Bombay: Popular Prakashan, clearly distinguishes earlier strata of Pāli Nikāya, Vinaya, and Sutta Nipāta texts from later Jätakas and Abhidharma texts, but his assertion that "the Nikayya and Vinaya material can safely be taken as a reliable guide to conditions during 500-300 BC" (1966: 3) needs further qualification, since there are very few texts among these collections that can be reliably dated before the third century BCE.

${ }_{17}$ Patrick Olivelle's comments on the social background of the Upanisads (Olivelle, Patrick. 1996. Upanișads. Oxford: Oxford University Press, xxiv-xxix) are directly relevant to Śākyamuni Buddha's context. However, Dharmasūtras, which are more concerned with maintaining separate varnas, belong to periods later than the middle of the third century BCE, according to Olivelle (1999. Dharmasutras: the Law Codes of Ancient India. Oxford: Oxford University Press, xxxii-xxxiii). Olivelle compiles Dharmasütra passages on the varna system in 2005. Dharmasütra parallels: containing the Dharmasūtras of Āpastamba, Gautama, Baudhāyana, and Vasiștha. Delhi: Motilal Banarsidass, 41-50.

18 Bailey and Mabbett 2003: 42-3 cite numerous Pāli passages listing degraded families (nīcā kulā) of candālas, hunters, bamboo workers, chariot-makers, and refuseremovers in juxtaposition to a list of people reborn into high families of wealthy warriors, priests, and householders.

19 Bailey and Mabbett 2003: 108-129, Chakravarti 1987: 39-46.

${ }^{20}$ Bailey and Mabbett 2003: 196 ff. (Chapter 9: The Dhammapada and the images of the Bhikkhu).

${ }^{21}$ It is interesting to note that the Brāhmana Varga is the first chapter of the Khotan Gāndhārī Dharmapada (Brough 1962: 119-125), but the final chapter of the Sanskrit Udānavarga (Bernhard, Franz, ed. 1965. Udānavarga. Göttingen: Vandenhoeck \& Ruprecht., 1.460-509) and the Pāli Dhammapada (Norman, K. R., trans. 1997a. The word of the doctrine (Dhammapada). Oxford: The Pali Text Society, 55-59). The first Gāndhārī verse (Brough 1962: 119, 178, pl. I) corresponds partially to Pāli Dhammapada 393, 265, 267 and Sanskrit Udānavarga 33.8 (Bernhard 1965: 462). 
Although the Buddha is sometimes portrayed in modern accounts as a social reformer or revolutionary through selective citation of passages critical of Brahmins, ${ }^{22}$ social contexts reflected in Buddhist literature are probably best understood against a background of dynamic social change rather than reactions against stagnant social hierarchies.

Buddhist hagiographic traditions clearly acknowledge that Ājīvikas and Jain śramana movements competed for religious and intellectual eminence in northern India when Siddhārtha renounced his duties to become a wandering mendicant. In accounts of the six years prior to his awakening in Bodh Gaya, Siddhārtha encountered other śramana proponents of heterodox viewpoints and ascetic practices. ${ }^{23}$ Johannes Bronkhorst provocatively argues that a "fundamental spiritual ideology" shared in common by Buddhism, Jainism, and Ājīiikism was "a product of the spiritual culture of Greater Magadha" (2007: 28), which had "... a culture of its own which was different from the culture of the authors of Vedic and early post-Vedic literature" (2007: 9).$^{24}$ Although Bronkhorst's attempt to localize shared assumptions about rebirth and karmic retribution in Magadha is not ultimately convincing, his point that early Buddhist doctrines were formulated in the context of debates between different śramana communities rather than in reaction to "Hindu" religious ideas and norms resonates with Louis de la Vallée Poussin's opinion that "the Brāhmanism from which Buddhism sprang is not the Brāhmanism of the Brāhmaṇa and the Upanișad, but represents, even better than the latter, the ancient Indian yoga" (quoted by Lamotte 1988 [1958]: 7).

${ }^{22}$ Remarking that "To present him as a sort of socialist is a serious anachronism" (2006: 30), Richard Gombrich rejects attempts to portray the Buddha as a social revolutionary (Gombrich, Richard F. 2006. Theravāda Buddhism: A social history from ancient Benares to modern Colombo. 2nd rev. ed. London: Routledge [1st ed. 1988]).

${ }^{23}$ Pāli, Sanskrit, Chinese, and Tibetan versions of the Srāmanyaphala-sūtra (MacQueen, Graeme. 1988. A study of the Śrämanyaphala-sūtra. Wiesbaden: O. Harrassowitz) may now be compared with a partial Gāndhārī manuscript version in the second scroll of the Senior collection (Allon, Mark. 2007. "Introduction: The Senior Manuscripts.” In Glass 2007a: 8; Salomon 2003c: 79-80).

${ }^{24}$ Bronkhorst, Johannes. 2007. Greater Magadha: Studies in the Culture of Early India. Leiden/Boston: Brill. Also see Bronkhorst, Johannes. 2004. "Hinduism and Buddhism." In Buswell 2004: 1.329. In my review of Bronkhorst 2007 (Journal of the Royal Asiatic Society 18.3 [2008], 381-3), I do not accept Bronkhorst's localization of a single underlying "spiritual ideology" exclusively in Magadha (however broadly he intends to define the cultural region as wherever the historical Buddha lived) because the origins of basic ideas about rebirth, karmic retribution, the self, and ascetic practices probably belonged to a more extensive geographical and cultural milieu. 
What is at issue is the extent to which basic theories of a self (atman) that transmigrates through the cycle of continuous rebirth (the samsāra paradigm) originated internally from the Vedic background or were introduced through processes of inter-religious contact, structural developments of rebirth eschatologies, or other external possibilities. ${ }^{25}$ While certain Vedic ideas and practices (such as animal sacrifice and Brahminical authority) are clearly rejected by Jains and Buddhists, the composers of the early Upanișads (particularly the Brhadàranyaka Upanișad and Chāndogya Upanișad) were also questioning, challenging, and reformulating Vedic rituals, cosmologies, and established mores. Since śramaña traditions and the early Upanișads belong to a similar climate of intellectual ferment in northern India during a period of significant social and religious change, scholars have attempted to establish relative chronological relationships and to identify directional influences. In contrast to the consensus view that Buddhism and Jainism "emerged not long after the composition of the early Upanișads" (Olivelle 1996: xxiii), Bronkhorst argues that "at least some portions of the early Upanișads-perhaps precisely the portions that introduce the belief in rebirth and karmic retribution into the Veda-were composed more or less at the time of the Buddha, or later" (2007: 258). Although K.R. Norman finds “... echoes of Upanișadic statements in the Buddha's sermons" (1997b: 33), especially in the opposition between the Buddhist doctrine of "no self" (Sanskrit anātman / Pāli anattā) and the equivalence between the individual self (ätman) and universal self (brahman) in the Chändogya Upanișad, it is not clear that Buddhists were responding to specific passages in early Upanișads. ${ }^{26}$ Instead of postulating that Buddhist ideas developed in reaction to prior speculations in the early Upanișads, it seems quite likely that they emerged from a shared nexus of intense intellectual

${ }^{25}$ Obeyesekere, Gananath. 2002. Imagining Karma: Ethical Transformation in Amerindian, Buddhist, and Greek Rebirth. Berkeley: University of California Press describes this theory as a "karmic eschatology" and proposes structural parallels with theories of rebirth in other cultures.

${ }_{26}$ Although he acknowledges possible similarities in thought and language, Bronkhorst rejects Norman's arguments for a specific link between the Buddhist doctrine of anattā as expressed in in the Alagaddūpama Sutta (Majjhima Nikāya I 136) and the equation of àtman and brahman attributed to Saṇ̣̃ilya in the Chāndogya Upanișad by pointing out that the Păli sutta does not mention the concept of brahman and the notion of a permanent "immutable" self is "largely absent from the early Upanișads" (2007: 217). Bronkorst dismisses other "superficial similarities" (2007: 218) proposed by Richard Gombrich as evidence for early Buddhist familiarity with Upanișads. 
and philosophical debate and competition with other śramanas and Brahmins in the middle of the first millennium BCE.

Economic conditions of rural prosperity, urban growth, political consolidation, and expanding trade networks contributed to the institutional organization of the Buddhist saingh, which emerged in an environment of material prosperity rather than hardship. While agricultural surplus was not the only causal factor of a "second urbanization" in the Ganga-Yamuna doāb following a long hiatus of about a millennium from the "mature phase" of the Indus Valley civilization (ca. 2300-1800 BCE), urban centers remained "predator[s] on the countryside" (Erdösy 1987: 17). ${ }^{27}$ Although the presence of Northern Black Polished (NBP) ware beginning ca. 550 BCE in the eastern Ganges plain is a sign of "incipient urbanism" (Thapar 2003: 140), ${ }^{28}$ archaeological evidence does not display traits of "thriving urbanisation" (Erdösy 1987: 14) until the third century BCE. Buddhist literary references to large cities at the time of the Buddha have led many interpreters, including Max Weber, to posit causal relationships between the growth of cities and the emergence of Buddhism..$^{29}$ However, Gregory Bailey and Ian Mabbett criticize the "urbanization hypothesis" as a "post hoc ergo propter hoc fallacy" of "treating effects as causes" (2003: 34). They acknowledge that the Pāli canonical texts on which they depend to support their argument that Buddhism arose after a period of rapid urbanization belong to later periods (2003: 4), but nevertheless base their analysis of economic and social contexts from the fifth century BCE down to the time of Aśoka almost exclusively on this problematic textual tradition, which "does not coincide with the earliest phase of urbanization, but with the more mature period" (Thapar

27 Erdösy, George. 1987. "Early Historic Cities of Northern India." South Asian Studies 3, 1-23.

${ }^{28}$ Thapar, Romila. 2003. Early India: From the origins to AD 1300. Berkeley: University of California Press refers to a general pattern in which "Closely placed, small settlements of the Painted Grey Ware gave way to appreciably larger settlements..." (140) associated with NBP. Erdösy, George. 1995. "City States of North India and Pakistan at the Time of the Buddha" in Allchin 1995: 100-105 reviews the chronology for the appearance of NBP, and concludes that 550-400 BCE is the most likely date for its early phase, a date which is considerably later than ca. 700 BCE proposed for the beginning of the NBP phase at Sringaverapura cited by other authorities, including Chakrabarti 1995: 169.

${ }^{29}$ Bailey and Mabbett 2003: 35 and Gombrich 2006: 50 refer to Max Weber's view that "... Buddhism presents itself as a product of the time of urban development, of urban kingship and the city nobles” (Weber 1958: 204). 


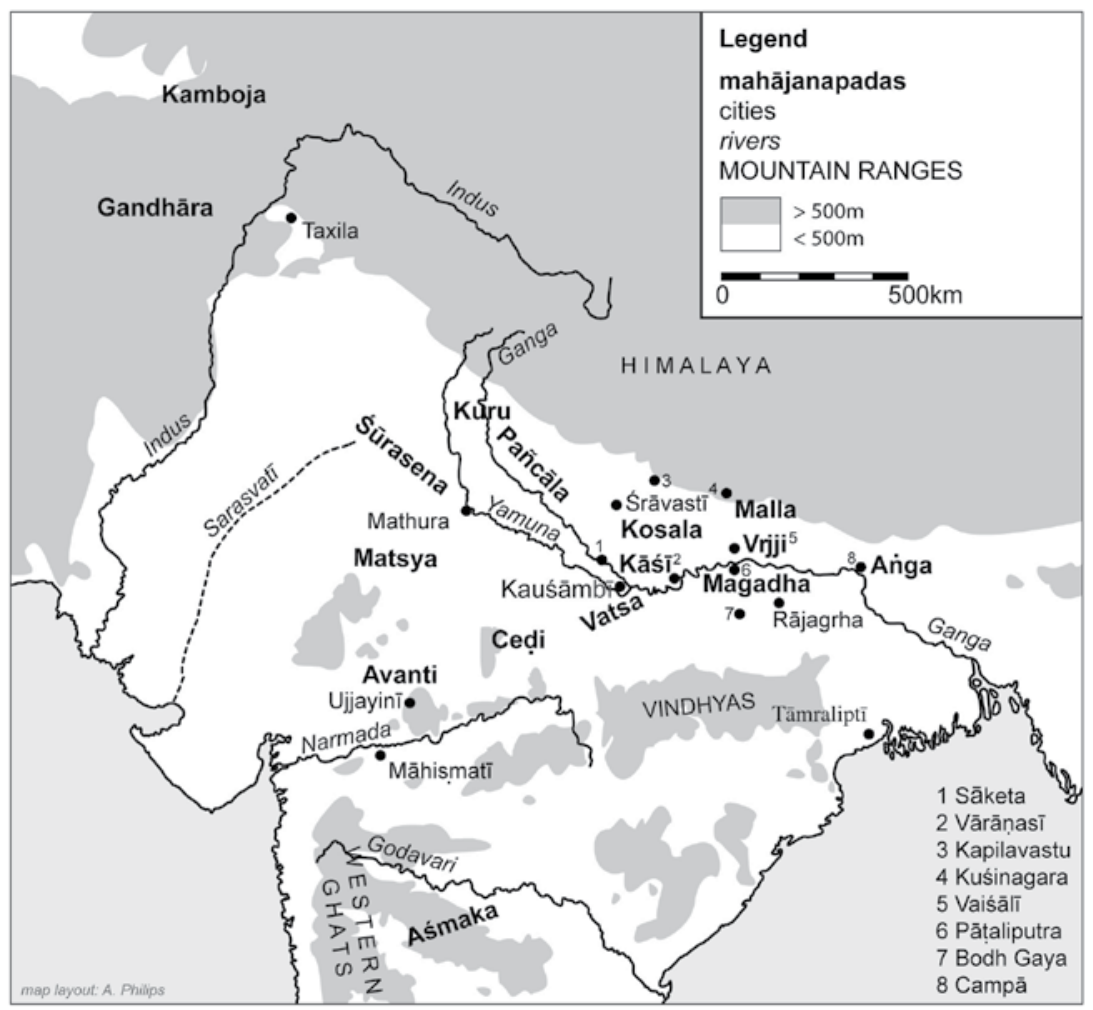

Map 2.1: Sixteen Mahājanapadas of ancient India ${ }^{30}$

2003: 140). Thus, many features reflected in archaeological and textual sources from this general period in the late first millennium CE, including the expansion of local, regional, and long-distance trade networks, must instead be seen as concurrent with rather than prior or posterior to the formation of early Buddhism.

Later Buddhist, Jain and purānic sources refer back to sixteen "great countries" (mahäjanapadas) of ancient India which competed for political and economic preeminence in the mid-late first millennium BCE. ${ }^{31}$ Rather than designating states with fixed boundaries, the term

\footnotetext{
30 Adopted from Allchin 1995: 116, fig. 7.4.

${ }^{31}$ Raychaudhuri, Hemchandra. 1923. Political History of Ancient India from the accession of Parikshit to the extinction of the Gupta dynasty. Calcutta: University of Calcutta, 1923, 45-79 compiles references to rulers of the mahajjanapadas in Buddhist, Jain, and purānic sources, which belong to varying periods. Lamotte 1988 [1958]:
} 
janapada generally corresponds to a "socio-cultural region" (Wagle 1966: 30) composed of smaller units of villages, towns, and cities. Thus, the major janapadas are closely linked with the emergence of urban administrative capitals. The geographical distribution of these territories extended from the Northwest (Gandhāra and Kamboja) to central and southern India (Avanti, Cedi, and Asmaka), with the heaviest concentration in the Ganges basin (including Magadha and Anga at the eastern extreme). This range was much broader than the Brahmanical limits of the "Land of the Āryas" (Āryāvarta), which is defined in the Dharmasūtras and the Mahābhāsya of Patañjali (probably second century $\mathrm{BCE}$ ) as "The region to the east of where the Sarasvati disappears, west of Kàlaka forest, south of the Himalayas, and north of the Pāriyātra mountains" (Olivelle 2005: 36). ${ }^{32}$ The exclusion of Magadhans and other easterners from the Brahminical heartland of Āryāvarta may suggest that they were "still not completely brahmanized" (Lamotte 1988 [1958]: 7). Romila Thapar observes that the widening of geographical horizons in Jain and Buddhist traditions parallels an eastward shift in the religious "epicentre" (2003: 138) from Vedic centers in the west to the northeastern regions where śramana movements originated and flourished.

7-8 lists the 16 great countries with their capitals based on Mahābhärata 8.40.29-8.45.14-16, 28, 34, 40, Mahāvastu 1.34, and Dīgha Nikāya III, p. 200. Kirfel, Willibeld. 1920. Die Kosmographie der Inder nach den quellen dargestellt. Bonn; Leipzig: K. Schroeder, 255-6 refers to Jain sources, but only six mahäjanapadas overlap. Tripathi, Rama Shankar. 1942. History of Ancient India. Delhi: Motilal Banarsidass, 82-85 adds references to Anguttara Nikāya I, 213, IV, 252, 256, 260. Law, Bimala Churn. 1932. Geography of Early Buddhism . London: Kegan Paul, Trench, Trübner \& Co. (reprint, New Delhi: Oriental Books Reprint Corporation, 1979), 2 ff. provides further details. For variants, see Fussman, Gérard. 1987-1988. "Histoire du monde indien: Les populations de l'Inde ancienne, d'après les texts." Annuaire du Collége de France 1987-88, 579-585. Fussman comments that the list of 16 mahajanapadas should be interpreted only in cultural and ideological terms rather than as a document of political history (1987-88: 582). Erdösy 1995: 115 and Thapar, Romila. 1995. “The First Millennium BC in Northern India." In Thapar 1995: 111 harmonize literary and archaeological evidence.

${ }^{32}$ This definition of Āryāvarta is found in Baudhāyana Dharmasūtra (1.2.9), Vasiștha Dhamasūtra (1.8) and in Mahābhāsya (I p. 475 1. 3). In Mānavadharmaśästra 2.21-22 (maybe second century CE), virtually identical boundaries ("The land between the Himalaya and Vindhya ranges, to the east of Vinaśana and west of Prayāga") correspond to the "Middle Region" (madhyadeśa), while Āryāvarta more broadly includes areas "from the eastern to the western sea" (Olivelle, Patrick, trans. 2004. The Law Code of Manu, Oxford: Oxford University Press, 24). 
A realignment of political power among the rulers of northeastern India is illustrated in Buddhist texts, which emphasize the importance of early patrons. During Sākyamuni's lifetime, the kingdom of Magadha vied with Kosala for control of northern India. ${ }^{33}$ Since the Buddha stayed in Śrāvastī, the capital of Kosala, during many rainy seasons (varșavāsa), King Prasenajit is depicted as a prominent patron, along with his chief queen Mallikā and other local donors, especially the wealthy merchant Anāthapinḍada. ${ }^{34}$ For example, a story about the Buddha's acceptance of an invitation from Anāthapiṇadada's female servant Puniga (Sanskrit: Pūrṇikā; Pāli: Puṇnikā or Puṇnāa is briefly summarized in an avadāna in a first century Kharoșțī manuscript:

Puniga was the ( ${ }^{*}$ maid) of the householder Anasapiḍiga (Anāthapiṇ̣ada). The Bhagavat was addressed by King Praseniga (Prasenajit). The Buddha did not agree [to his request] ... and he did not agree [to the request] of all the householders. ${ }^{35}$

This narrative exemplifies the role of female patrons, including individuals like the maidservant Punniga, whose offer to the Buddha to stay in Srāvastī is deemed more sincere than invitations from Prasenajit, Anāthapiṇ̣ada and other wealthy male householders. However, the localization of Buddhist literary narratives in Kosala is a common archetype, since Śrāvastī during the reign of Prasenajit is the formulaic setting for numerous discourses attributed to the Buddha. ${ }^{36}$

Under King Bimbisāra, a brother-in-law of Prasenajit who was also lauded as a patron of the early Buddhist community, Magadha became the most powerful kingdom in northern India, with the capital at Rajjagrha regarded as a wealthy center and major site for the early

${ }^{33}$ Lamotte 1988 [1958]: 10-12, Raychaudhuri 1923: 199-209, and Tripathi 1942: 89 describe relationships between the four major kingdoms of Vatsa ruled by Udena, Avanti ruled by Pradyota, Kosala ruled by Prasenajit, and Magadha ruled by Bimbisāra, while Thapar lists the "four rival states" (2003: 151) as Kāśí, Kośala, Magadha, and the the Vrijji oligarchy.

${ }_{34}$ Malalasekera 1937: s.v. Anāthapiṇ̣ika, Kosala, Mallikā, Pasenadi (Pāli citations).

35 Allon 2001: 304 (Appendix 2: The Gāndhārī Avadāna of Puniga). A Pāli version of this episode is preserved in Manorathapürani ${ }^{4.34-5}$ (also see Malalasekera 1937: sv. Punnāa Therī 3 for further citations to verses attributed to her in Therīgāthā 236-251).

${ }^{36}$ Schopen, Gregory. 1997b. "If You Can't Remember, How to Make It Up: Some Monastic Rules for Redacting Canonical Texts." In Bauddhavidyāsudhākarah: Studies in Honour of Heinz Bechert on the Occasion of His 65th Birthday, ed. Petra KiefferPülz and Jens-Uwe Hartmann. Swisttal-Odendorf: Indica et Tibetica Verlag, 571-582 [= Schopen 2004: 395-407]. 
Buddhist saingha. ${ }^{37}$ Ajātaśatru, the infamous parricide who imprisoned and starved Bimbisāra to death eight years before the Buddha's parinirvāna, further consolidated Magadhan control of overland routes and established a small fort at Pātaligrāma, which later became the city of Pātaliputra. Despite his connection with a failed attempt by Devadatta to assassinate the Buddha, Ajātaśatru later hosted the Buddha and his entourage in Rājagṛha before his final journey to Kuśinagara. Ajātaśatru and his ministers play major roles in the events preceding and following the Buddha's Mahāparinirvāna. Ajātaśatru continued to rule for another 24 years, followed by five successive parricides, rule by the minister Siśunāga, and the rise and fall of the Nanda dynasty. ${ }^{38}$ Although the historical memory of these figures preserved in religious and literary sources can not be corroborated by coins, inscriptions, or reliable historiographical traditions from outside of South Asia, the emergence of the Mauryan empire based in Magadha coheres well with archaeological evidence for the growth of powerful cities in the prior period.

\section{Legacy of the Mauryans: Aśoka as Dharmarāja}

Mauryan control of important nodes along overland routes in the Indian subcontinent significantly influenced early patterns for the growth and expansion of the Buddhist sarigha. While the sangha's

${ }^{37}$ Chronological details connected with Bimbisāra's genealogy and reign remain unclear. Raychaudhuri acknowledges that "There is considerable disagreement between the Purānas and the Ceylonese Chronicles regarding the chronology of the kings of the Bimbisārian (or Nāga) and Saiśunāga dynasties" (1923: 116). Magadhan dynastic genealogies in Buddhist and Jain sources are compiled by Lamotte 1988 [1958]: 87-104 and Tripathi 1942: 113-114, who gives a separate table following purānic chronologies, which limit his reign to 28 rather than 52 years (Tripathi 1942: 94, fn. 1). According to Lamotte 1988 [1958]: 4, Magadha was organized as a kingdom only during the Buddha's time.Tripathi 1942: 104-108 comments on economic conditions and Thapar 2003: 152-155 discusses administration. The total of 200 years for the total length of the reign of Bimbisāra, Ajātaśatru, and their successors until the time of the first Nanda ruler in chronologies reported by Pāli vamsas is very suspicious, while purānic alternatives transpose numerous figures.

38 If a short chronology for the Buddha's parinirvana around 370 BCE is adopted, only about 30 years is allowed between the end of Ajātaśatru's reign and Candragupta Maurya's accession. Pāli chronologies limit the "9 Nandas" to 22 years, but the reigns of Śiśunāga (Susunāga), and Kālāśoka and his ten sons would have to be telescoped from 68 years to less than 10 years. Lamotte 1988 [1958]: 89 doubts the existence of Kālāśoka, thus shortening the chronology. 
horizons were initially limited to the Ganges River basin in northern India during the time of the Buddha, the initial extension of Buddhist establishments throughout South Asia was greatly accelerated by high level support from the Mauryan emperor Aśoka, who is portrayed as an ideal patron in Buddhist literature. In comparison to what can only be vaguely known about conditions in the period of the historical Buddha, a wider variety of contemporary sources provide more reliable evidence of religious and political life during the Mauryan period from about the last quarter of the fourth century $\mathrm{BCE}$ to the beginning of the second century BCE. As the earliest written evidence for the study of ancient South Asia, Aśokan inscriptions directly indicate conditions in which Buddhist institutions began to flourish by the middle of the third century BCE. ${ }^{39}$ The fragmentary reports of Megasthenes, a Seleukid ambassador to the Mauryan court at Pātaliputra under Aśoka's grandfather Candragupta, preserve an outsider's cross-cultural perspective on India seen through Greek lenses. ${ }^{40}$ Candragupta and Aśoka are primarily remembered in Jain and Buddhist literature, but the literary images of these Mauryan rulers as exclusive patrons

${ }^{39}$ In addition to Hultszch 1925 and Falk 2006 cited in the first chapter (p. 52, fn. 147), also see translations by Bloch, Jules. 1950. Les inscriptions d'Asoka. Paris: Les Belles Lettres; Sircar, Dineschandra. 1967b. Inscriptions of Aśoka. Rev. ed. New Delhi: Publications Division, Ministry of Information and Broadcasting, Govt. of India; and Thapar, Romila. 1961. Aśoka and the Decline of the Mauryas: With a new afterword, bibliography, and index. London: Oxford University Press (revised edition, Delhi: Oxford University Press, 1997), 250-266. For further references to important studies of Aśokan inscriptions by Paul Kent Andersen, Colette Caillat, K.R. Norman, Ulrich Schneider, and previous scholars, see the extensive bibliography in Falk 2006: 13-54 and the general survey in Salomon 1998a: 133-140. A running tabulation includes 14 Major Rock Edicts inscribed at 9 locations, 6 Major Pillar Edicts at 6 sites (19-20 Aśokan pillars have been discovered, but not all are inscribed, and some are inscribed with edicts other than the set of 6 Major Pillar Edicts), similar versions of Minor Rock Edicts at 17 sites, separate edicts at 7 sites, 3 locations of cave inscriptions, and versions of Greek and Aramaic edicts. Updated editions of the entire corpus of Aśokan inscriptions remains a desideratum.

${ }^{40}$ McCrindle, John W. 1877. Ancient India as described by Megasthenes and Arrian. Calcutta: Thacker, Spink (Reprint, New Delhi: Today \& Tomorrow's Printers \& Publishers, 1972 available as e-book) translates fragments of Megasthenes quoted by various classical authors. Karttunen, Klaus. 1997a. India and the Hellenistic world. Helsinki: Finnish Oriental Society, 69-93 assesses scholarship on Megasthenes, emphasizing that he was "a Greek author writing to a Greek audience" (76). Also see remarks on Megasthenes by Lamotte 1988 [1958]: 221, Parker 2008: 42-47, and Thapar 1961 [1997]: 57-70; 2003: 177-8. 
exaggerate their religious affiliations at the expense of rival traditions. ${ }^{41}$ The Arthaśāstra attributed to Kauṭilya, Candragupta's Brahmin minister, presents itself as a guide to ancient Indian statecraft and political economy during the Mauryan period, although it primarily reflects much later third century CE conditions. ${ }^{42}$ In this survey of historical contexts for Buddhist transmission in Mauryan India, inscriptions of Aśoka are privileged over literary sources, which must be approached carefully with an understanding that biases of later periods have influenced how the Mauryan legacy is remembered.

Candragupta Maurya, the founder of the dynasty, seized control of Magadha after rising to power from obscure origins. Candragupta can be identified with Sandrokottos, an Indian ruler who may have encountered Alexander of Macedon during his expedition to Gandhāra, Punjab, and the lower Indus valley between 327-325 BCE. ${ }^{43}$ Based on a reported meeting between Candragupta and Alexander, historians propose that Candragupta probably began to rule between 324-313 BCE. ${ }^{44}$

${ }^{41}$ Buddhist literary sources on Aśoka are examined by Strong, John. 1983. The Legend of King Aśoka: A study and translation of the Aśokāvadāna. Princeton, N.J.: Princeton University Press. In "Aśoka and the Buddha Relics" (2004a: 124-149), Strong treats Buddhist traditions connected with Aśoka outside of South Asia. He remarks that "Aśoka was best known to Buddhists not through his edicts but through the legends that were told about him" (Strong, John. 2004b. "Aśoka." In Encyclopedia of Buddhism, ed. Robert Buswell, New York: Macmillan, vol. 1, 34).

${ }^{42}$ Kangle, R.P. 1969-. The Kautilīya Arthaśästra. University of Bombay studies, no. 1-2. [Bombay]: University of Bombay, 3 vols. The dating of the text is extensively discussed by Trautmann, Thomas R. 1971. Kautilya and the Arthaśāstra; a statistical investigation of the authorship and evolution of the text. Leiden, Brill. Thapar acknowledges that the text was reworked by Viṣnugupta in the third or fourth century CE, but still uses the text to treat Mauryan administration based on her opinion that "the institutions are in the main Mauryan" (1961: 224).

${ }^{43}$ Karttunen 1997a: 36-7, 257-264 suspects that the "Candragupta legend" may be apocryphal, but does not deny the possibility of a meeting with Alexander. Lamotte 1988 [1958]: 218-219 comments on references to the meeting with Alexander in accounts of Justin (15, 4, 12 ff.) and Plutarch (Life of Alexander, 62, 9). Bongard-Levin, G.M. 1998. Ancient Indian History and Civilization. Delhi: Ajanta (1st ed. New Delhi : Arnold-Heinemann, 1985), 64 adds further details about the supposed meeting, which could have taken place after Candragupta had initially attempted to overthrow the Nandas. According to Thapar 2003: 177, William Jones first identified Sandrocottus with Candragupta. Also see Raychaudhuri 1923: $137 \mathrm{ff}$.

${ }^{44}$ Lamotte 1988 [1958]: 219 claims that Candragupta seized power in 324 BCE, Thapar 2003: 175 states that the Mauryan empire was founded ca. 321 BCE, BongardLevin 1998: 65 favors 317 BCE, Karttunen 1997a: 259 suggests that he first participated in an uprising against Macedonian rule in the Northwest between 317-312 BCE, and Bechert 1989: 101 opts for 313 BCE based on Jain sources which date the accession of Candragupta 155 years after the Nirvāṇa of Mahāvīra in 468 BCE. 
In exchange for 500 trained war elephants, Candragupta acquired the northwestern provinces (including Gandhāra) from Seleukos Nikator, a successor of Alexander, in $303 \mathrm{BCE} \cdot{ }^{45}$ Although the extent of direct administrative control is unclear, the expansion of Mauryan power from Magadha to Gandhāra under Candragupta essentially unified the older mahajjanapadas along the "Northern Route" (uttarāpatha) for the first time in South Asian history. ${ }^{46}$ According to Jain traditions, Candragupta stepped down to accompany the Jain elder Bhadrabāhu to Sravana-Belgola in South India, where he fasted to death. ${ }^{47}$ Candragupta's successor, Bindusāra, may have extended Mauryan dominion further into the Deccan peninsula and favored the Ājivikas while ruling for a period of about 25 years, but his reign is not documented as well as those of Candragupta and Aśoka. ${ }^{48}$

The Mauryan empire reached its zenith during the reign of Aśoka (ca. 270-232 BCE), whom Buddhist traditions revere as an ideal emperor (cakravartin), although he is virtually ignored by other traditions until his rediscovery in the nineteenth century. Aśoka's murky background may support Buddhist literary accounts in which he assumed the throne as "Aśoka the cruel" (Caṇ̣āśoka) after a struggle with rival

45 For discussion and references, see Kartunnen 1997a: 261 and Lamotte 1988 [1958]: 220. Tarn, W.W. 1984 [1951]. The Greeks in Bactria and India, 3rd ed. Chicago: Ares, 100 discusses the geographical extent of Seleukid territories ceded to Candragupta, but Karttunen 1997a: 263 points out that Greek and Aramaic inscriptions of Aśoka in Afghanistan indicate that the ceded territories were more extensive. Seleukos Nikator used the elephants acquired from Candragupta to defeat Antigonus at the battle of Ipsus in 301 BCE (Bernard, Paul. 1994a. "The Seleucids in Central Asia." In History of Civilizations of Central Asia, vol. 2: The development of sedentary and nomadic civilizations: 700 BC to AD 250, ed. János Harmatta. Paris: Unesco, 90).

${ }^{46}$ Northern Route (Uttarāpatha) is discussed in detail in the third chapter (pp. 186-203). Fussman, Gérard. 1987b. "Central and Provincial Administration in Ancient India: The Problem of the Mauryan Empire" Indian Historical Review 14.1-2, views Candragupta's use of military force to expand Mauryan dominion as the impetus for a "complex administration" with a "communications network" (55) along a system of roads described by Megasthenes and referred to in Aśokan inscriptions, but points out that administrative control was not necessarily centralized in Pātaliputra since provincial officials had considerable autonomy.

47 Lamotte 1988 [1958]: 221-2; Thapar 1961: 17, 2003: 178.

${ }^{48}$ Lamotte 1988 [1958]: 222-3; Thapar 1961: 17-18, 2003: 178. Bindusāra ruled for $27 / 28$ years according to Pāli vaṃsas, 25 years according to purānic chronologies. These figures can be calculated from the date of Aśoka's consecration (ca. $270 \mathrm{BCE}$ ), although Pāli traditions refer to a 4 year hiatus between the death of Bindusāra and Aśoka's reign. 
contenders, who were eliminated in fratricidal conflicts. ${ }^{49}$ However, Pāli narratives of mass slaughter of ninety-nine brothers are likely to have been embellished, since Aśoka refers to his brothers and sisters in inscriptions..$^{50}$ In the Divyāvadāna, Aśoka's subjugation of a revolt while he was serving as heir-apparent prince in Taxila suggests instability before he became the Mauryan ruler, but Pāli chronicles place him in Ujjain instead of Taxila. ${ }^{51}$ In any case, the gory details behind Aśoka's rise to power figure prominently in literary biographies, which portray him as an especially cruel and violent ruler before his transformation into a Buddhist patron.

As discussed in the previous section, dates for the historical Buddha hinge upon Aśoka's consecration in the middle of the third century BCE. Aśokan inscriptions are not dated in a continuous era that can be correlated with the Common Era, but references to five contemporary Hellenistic rulers in the 13th Major Rock Edict issued after the 13th year of his reign serve as "the bedrock of the chronology of Indian history, interlocking the date of the Mauryas with Hellenistic kings" (Thapar 2003: 182). ${ }^{52}$ The synchronism between the dates for these rulers and the internal chronology of Aśoka's regnal years establishes almost certain dates for the beginning of his rule between 274-268 $\mathrm{BCE}$, making a consecration around $270 \mathrm{BCE}$ (or slightly later) fairly

49 Lamotte 1988 [1958]: 249 refers to Dīpavamsa VI, 21-2, Mahāvamsa V, 20-21, 39-40, 189, Samantapāsādikā p. 41, and Mahābodhivaṃsa pp. 98-99. Mookerji, RadhaKumud. 1962 [1928]. Asoka. 3rd rev. ed. Delhi: Motilal Banarsidass, 3-4 contrasts Sanskrit accounts of Aśoka's violent rise to power in the Aśokāvadāna of the Divyāvadāna (chapter 26) with Pāli narratives, concluding that "The northern and southern legends, however, agree as regards the disputed succession, which may therefore be taken as fact" (1962 [1928]: 4).

${ }^{50}$ Bloch 1950: 105 and Hutszch 1925: 192 provide a synoptic tables for a passage in the 5th Major Rock Edict in which Aśoka refers to the households of his brothers, sister, and other relatives.

${ }^{51}$ Lamotte 1988 [1958]: 223; Mookerji 1962 [1928]: 3 refer to Dìpavamsa VI, 15 and Mahāvamsa V, 39. Strong 1983: 209-209 translates the passage from Divyāvadāna (pp. 370-371 in Cowell, Edward B. and Robert Alexander Neil, eds. 1886. The Divyâvadâna, a Collection of Early Buddhist legends. Cambridge: University Press).

52 Bloch 1950: 130 and Hultszch 1925: 210 gives synoptic texts of the 13th Major Rock Edict based on versions from Girnar, Kalsi, Shahbazgarhi, and Mansehra. Amtiyoga is identified with Antiochus II Theos of Syria (261-246 BCE), Tulamaya with Ptolemy II Philadelphus of Egypt (285-247 BCE), Antekina with Antigonus Gonatas of Macedonia (276-239 BCE), and Maka with Magas of Cyrene (deceased before 250 BCE). Alikyashudala (Alikasudara in Kharosthī) can be identified with Alexander of Epirus (272-255 BCE) or Alexander of Corinth (252-244 BCE). 
sure. ${ }^{53}$ This approximate date not only provides the crucial linchpin for the history of South Asian Buddhism, but also has important ramifications for the relative chronology of ancient Indian political, intellectual, and cultural history.

Patterns of distribution of Aśokan inscriptions indicate the geographical extent of the Mauryan empire at its peak (Map 2.2: Distribution of Aśoka's Inscriptions). Major Rock Edicts located in the Mauryan borderlands demonstrate that Aśoka's domain eventually extended to ancient Kalinga (modern Orissa) in eastern India, the western coast of India (Girnar in Gujarat and Sopara in Maharashtra), southern India (as far as Suvarnagiri in Karnataka), and the northwestern frontiers in modern Pakistan and eastern Afghanistan. While most of Aśoka's inscriptions are written in Middle-Indo-Aryan Prakrit vernacular languages using the Brāhmī script (which was probably developed for this purpose during the Mauryan period), Major Rock Edicts written in Kharoșthi at Mansehra and Shahbazgarhi (in northwestern Pakistan) reflect linguistic and cultural differences within the Mauryan realm. ${ }^{54}$ Greek and Aramaic versions of Aśokan inscriptions from Kandahar (southeastern Afghanistan) show that Mauryan officials also used non-Indic administrative languages and scripts for transmitting imperial messages. ${ }^{55}$

In addition to supplying concrete evidence for the dates of his reign and the territorial boundaries of his empire, inscriptions issued by Aśoka refer to administrative policies, patronage of various religious communities, and the application of his principles of Dharma. Aśoka addressed his orders to various officials who were responsible for writing and transmitting his instructions. For example, the Rājukas (rural

53 Bongard-Levin 1998: 68 proposes an absolute date of 268 BCE for Aśoka's consecration based on an astronomical calculations of a solar eclipse in 249 BCE, which he proposes to link with Aśoka's pilgrimage to Lumbini in his twentieth regnal year based on literary references to a solar eclipse during his tour of Buddhist sites. Some additional time may be allowed for communications about contemporary rulers to filter through the ancient world to Aśoka's court (Karttunen 1997a: 266).

${ }^{54}$ Salomon 1998a: 73-75.

${ }^{55}$ Pugliese Carratelli, Giovanni and Giovanni Garbini. 1964. A Bilingual GraecoAramaic edict by Aśoka: The first Greek inscription discovered in Afghanistan. Roma: Istituto italiano per il medio ed estremo Oriente. Falk 2006: 241-254 updates references to publications of Greek and Aramic inscriptions of Aśoka from Kandahar, and points that Aramaic inscriptions from Taxila, Laghman, and Pul-I Darunta are not versions of Aśokan edicts. Fussman 1987b: 59-60 comments on the non-standardized bureaucratic use of foreign languages and scripts and Karttunen 1997a: 268-270 differentiates the use of Aramaic as a chancellery language from Greek translations for a foreign Hellenized audience. 


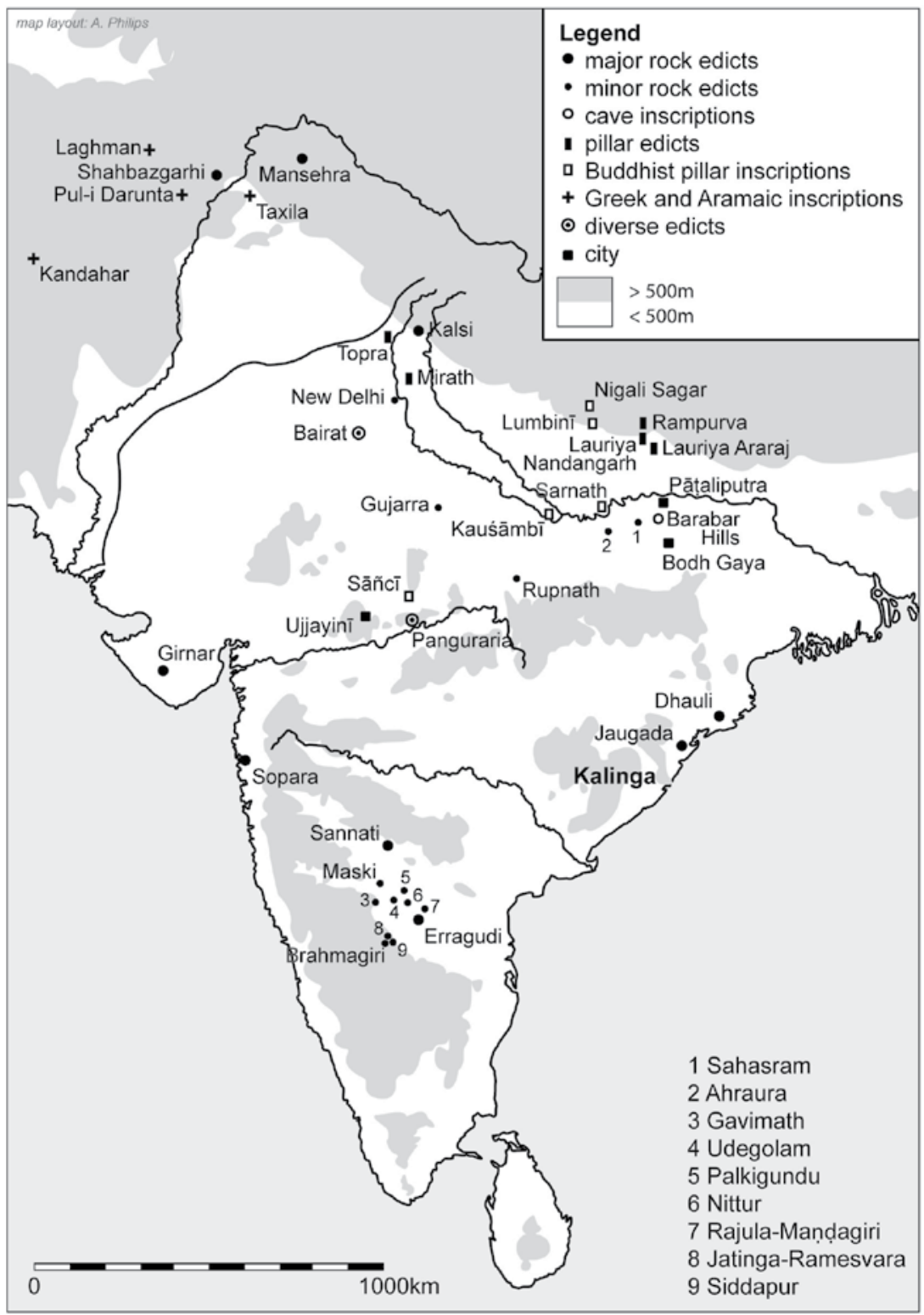

Map 2.2: Distribution of Aśokan inscriptions (based on coordinates in Falk 2006) 
officials) who were appointed for "the welfare and happiness of the country people" were given "independent authority in judgement and punishment" although he instructs them to allow a respite of three days to men condemned to capital punishement. ${ }^{56}$ Passages in several inscriptions seem to reflect an ideal view that ethical interactions should transcend social and religious differences. He encouraged his subjects to perform Dharma ceremonies which promote "regard for slaves and servants, respect for teachers, restrained behavior towards living beings, and donations to śramanas and Brahmins" the "gift of Dharma" (Dhammadāna / Dhramadane) as "good behavior towards slaves and servants, obedience to mother and father, generosity towards friends, acquaintances, and relatives and towards śramanas and Brahmans." ${ }^{\prime 8}$ Other passages called for generous donations to both Brahmans and śramanas and expressed a tolerant attitude towards "all sects" (Bloch 1950: 121) or "religious communities" (Sircar 1967b: 55):

King Priyadarśin, Beloved of the Gods, honors all religious groups (pāsamida, prasaṃda), both ascetics and householders, with various gifts and honors. But the Beloved of the Gods does not consider gifts or honors to be as valuable as increasing what is essential for all religious groups. This increase in what is essential is manifold, but its basis is restraint of speech, so as not to extol one's own religious group or denigrate others' at improper occasions, or only do so mildly on appropriate occasions. ${ }^{59}$

Although Aśoka promoted "restraint of speech" (vacigutti), the admonition against sectarian polemics reflects intensive competition between groups of Brahmans and śramanas for imperial patronage. Inscriptions lauding generosity to Brahmans and recording donations of caves to the Ājivikas at Barabar indicate that Aśoka's patronage

${ }^{56}$ Translation of in the 4th Pillar Edict issued in his 26th regnal year follows Thapar 1961: 263, who also discusses this pillar edict in more detail (1961: 103-108). Fussman explains that the expression janasa athe refers to "the material affairs, the material happiness of the people" (1987b: 57).

${ }_{57}$ 9th Major Rock Edict (Thapar 1961: 254).

58 11th Major Rock Edict (Thapar 1961: 254-255).

59 12th Major Rock Edict, with modifications based on translations by Bloch 1950: 121-122, Sircar 1967b: 55, and Thapar 1961: 255. 
extended to multiple religious communities and not exclusively to Buddhists. ${ }^{60}$

The promulgation of "Dharma" in Aśoka's inscriptions raise questions about the role of the Mauryan state in the growth of Buddhist institutions during his reign. Before addressing this issue directly, it is necessary to recognize that Aśoka interpreted Dharma broadly as religious piety, personal morality, and social ethics applicable to his entire realm rather than adopting a specifically Buddhist sense of the term. The governing principles of Dharma are succinctly defined in the 2nd Pillar Edict:

Dharma is good. And what is Dharma? (It is) few faults, abundant virtues, compassion, generosity, truthfulness, and purity. ${ }^{61}$

Aśoka's view of Dharma encompasses ideals of nonviolence, tolerance, moderation, and respect for parents, teachers, and elders, which are drawn from a wide variety of orthodox Brahmanical perspectives and heterodox Buddhist, Jain, and probably Ājīvika values. Since Buddhist doctrines of the Four Truths, Eightfold Path, "no self" (anātman), or release from rebirth through the attainment of nirvanna are not mentioned in non-Buddhist inscriptions, scholars have debated the extent to which Aśoka intended to implement Buddhist principles or appropriated certain elements to formulate official propaganda to unify disparate religious groups within the Mauryan empire with an acceptable ideology. Although Richard Gombrich and Romila Thapar, for example, hold that Buddhist ideas inspired Aśoka's formulation of Dharma, K.R. Norman regards his Dharma policy as "exclusively a moral one" with "no hint of anything exclusively Buddhist" (1997b: 117) ${ }^{62}$ In sets

${ }^{60}$ Falk 2006: 258-269 re-examines the architecture and inscriptions of the Barabar caves, and presents a new reading and translation of three donations by Aśoka in his 12th and 19th regnal years. The excavation of caves in the Nāgārjuni hills (nearby Barabar) donated to the Ājivivikas by Daśaratha, one of Aśoka's descendants, may have begun while Aśoka was ruling (Falk 2006: 257, 276).

${ }_{61}$ Bloch 1950: 162; Hultzsch 1925: 120-121; Sircar 1967b: 71; Thapar 1961: 262. It is interesting to note that dharma is translated as eusebeia ("piety") in a bilingual Greek-Aramic inscription and in partial Greek translations of the 12th-13th major rock edicts in Kandahar (Falk 2006: 242-245; Lamotte 1988 [1958]: 714-715; Pugliese Carratelli and Garbini 1964: 33). Bongard-Levin observes that the Greek term "conveys the idea of righteousness, not religious belief" and explains that Aśoka's moral precepts were "traditional ethical principles easily comprehended by various strata of the population regardless of their ethnic origin or religious allegiance" (1998: 79).

${ }_{62}$ Gombrich attempts to identify "distinctively Buddhist values" (2006: 131) in Aśokan inscriptions by pointing out similarities with prescriptions for Buddhist lay 
of major rock edicts and pillar edicts inscribed throughout the Mauryan domain, Aśoka appears to have maintained a distinction between the official Dharma and his own commitment as a Buddhist devotee, which he clearly expressed in other inscriptions discussed below.

The violent conquest of Kalinga was a pivotal turning point that caused Aśoka to express deep remorse and to adopt "Victory of Dharma" (dharmavijaya) as the goal of his rule. ${ }^{63}$ In the 13th Major Rock Edict, Aśoka declared that the impetus for him to practice, desire, and teach Dharma was the mass deportation of 150,000 people, killing of 100,000, and the subsequent loss of life of many more resulting from the subjugation of Kalinga during the eighth year of his reign. ${ }^{64}$ In this singular epigraphic record, Aśoka juxtaposes military conquests to the "Victory of Dharma" by proclaiming:

This Dharma inscription has been written so that my sons and grandsons would not pursue new conquests. They should delight their own minds, regarding real victory (won by) patience and leniency. They must realize Victory of Dharma is the real conquest. ${ }^{65}$

The bloodshed in Kalinga may have prompted Aśoka to embrace Jain and Buddhist principles of nonviolence (ahimsāa), but the application of this ideal was tempered by the need to suppress rebellions and punish criminals. In the same inscription, a threat to punish forest tribes makes it very clear that Aśoka was not willing to relinquish the use of violence if his power was threatened. ${ }^{66}$ Thus, Aśoka's admonitions

morality in Pāli texts such as the Sīgālovāda sutta and the Kütadanta sutta. According to Thapar, "... much of the ideology of Dhamma which he enunciated was inspired by Buddhism. But to equate it totally with Buddhism and to suggest that Aśoka was propagating Buddhism as a state religion is to read more into the edicts than was intended by the monarch" (1975: 42). Thapar believes that Aśoka's Dhamma served as a "group of unifying principles" (2003: 201) rather than a narrow sense of religious piety. Lamotte asserted that "Aśoka himself makes a clear distinction between his personal Dharma... and the Buddhist Law" (1988 [1958]: 228).

${ }^{63}$ Norman 1997b: 114-115 attributes Aśoka's Buddhist conversion to remorse for carnage in a war with Kalinga, but the chronology of the undated Minor Rock Edicts (which Norman believes were issued in his 11th regnal year) does not necessarily indicate that he became a Buddhist upāsaka after the Kalinga war.

${ }^{64}$ Norman's view that “...Aśoka expanded his empire by force, but thereafter devised the principle of victory by morality [Dharma] and commended it to his successors" (1997b: 118) seems apparent from the evidence of the 13th Major Rock Edict.

${ }_{65}$ Bloch 1950: 132; Sircar 1967b: 59; Thapar 1961: 256-257.

${ }^{66}$ Fussman's comments on this passage in the 13th Major Rock Edict help to clarify the apparent contrast between the ideal of nonviolence and its application: "...the 
against violence coupled with threats against resistance argue strongly against over-idealizing his image as a ruler who governed according to nonviolent principles, since it was still necessary for him to enforce Mauryan power.

Aśoka's inscriptions recording visits to Buddhist sites and addressed directly to the Buddhist sangha deserve particular attention for illuminating early pilgrimage practices, tensions within monastic cummunities, and the circulation of orally transmitted texts. Aśoka explicitly identifies himself as a Buddhist lay follower in fourteen versions of his Minor Rock Edicts composed in his tenth regnal year and distributed widely throughout the Mauryan empire:

Thus speaks the Beloved of the Gods. More than two and a half years have passed since I became a Buddhist layman (upāsake), but I was not zealous. Now more than a year has passed since I approached the sangha and have become more zealous. ${ }^{67}$

His visits to the site of the Buddha's awakening (sambodhi), Siddhārtha's birthplace at Lumbinī and the stūpa of the previous Buddha Konākamana at Nigāli Sāgar indicate a strong proclivity to Buddhist devotional practices. ${ }^{68}$ These epigraphic records show that his literary reputation as "the stūpa builder par excellence" (Strong 1983: 109) had some basis, although no Aśokan inscriptions discovered to

king's orders should be applied everywhere, even among the populations who live on the fringe of the Empire, under the threat of violent repression" (1987b: 51). More bluntly, "If persuasion did not succeed, there was always force" (ibid., 53).

${ }^{67}$ Andersen, Paul Kent. 1990. Studies in the Minor Rock Edicts of Aśoka. Freiburg: Hedwig Falk, 112-113, 123-124 presents a synoptic text and reconstructed edition of this passage in all 14 versions, but further in situ investigations of these sites by Harry Falk (2006: 55-103) have clarified many earlier readings. For translations, see Bloch 1950: 145-147 (synoptic translation and edition of Brahmagiri, Rupnath, etc.); Hutzsch 1925: xliv (commentary), 174-177 (Maski and Brahmagiri), 228 (synoptic edition); Sircar 1967b: 39-41 (Rupnath, Maski, Gujarra); and Thapar 1961: 259 ("a conflation of various versions). Also see comments by Norman 1997b: 115 .

${ }^{68}$ The assumption that sambodhi refers to the Bodhi tree shrine in Bodh Gaya is challenged by Basham, A.L. 1979. "Sambodhi in Aśoka's 8th Rock Edict." Journal of the International Association of Buddhist Studies 2, 81-83, who argues that this term refers Aśoka's own conversion ("awakening"). Konākamana, who precedes the previous Buddha Kāśyapa in the present Bhadrakalpa, is known elsewhere as Konāgamena (Bhārhut inscription B 16, Lüders 1963: 85-86), Konagamuni (Library of Congress ${ }^{\star}$ Bahubuddha-sūtra Kharoșțī scroll, Salomon, forthcoming), Koṇāgamana (Pāli, Malalasekera 1937: 1.681-2), and Koṇākamuni/Kanakamuni (Edgerton 1953 [BHSD]: 167). The Lumbini inscription is treated earlier in the previous section of this chapter, and see Falk 2006: 187-189 (Niglīiā) and Hultzsch 1925: 164-165 for Nigāli Sāgar. 
date are connected with the establishment of relics or the construction of stūpas of Śàkyamuni.

Three versions of the so-called "Schism edict" written on pillars at Sarnath, Sāñcī, and Kauśāmbī seem to indicate that Aśoka ordered his administrators to intervene directly in the affairs of the Buddhist saigha. Common to all three versions is an admonition against causing a split in the community: "Whoever creates a schism in the saingh, whether monk or nun, is to be dressed in white garments, and to be put in an uninhabited place." ${ }^{\prime 69}$ Although their interpretation remains disputed, the inscriptions refer to problems of division in the community (sainghabheda), which Aśoka may have been called upon to police. ${ }^{70}$ K.R. Norman (1997b: 122-129) compares the anti-schism edicts to different Pāli versions of a third communal recitation believed by the Theravāda tradition to have been held at Pạtaliputra during the time of Aśoka. Norman concludes that the Aśokan inscriptions and Pâli accounts of a third council do not necessarily refer to the same event, but suggests that Aśoka may have indirectly intervened to evict infiltrators who were not Buddhist monks or nuns from a royally supported monastery or monasteries.

A separate Aśokan edict found at Bairat in Rajasthan but brought to the Asiatic Society in Calcutta after its discovery recommends particular texts to Buddhist monks, nuns, laymen, and laywomen. ${ }^{71}$ While some identifications remain uncertain, the seven "discourses on dharma" (Prakrit: dhamma-paliyāyāni / Sanskrit: dharma-paryāyāhn) referred to in this inscription provide a valuable glimpse of the types of texts that were being circulated through oral transmission in the middle of the third century BCE. ${ }^{72}$ As K.R. Norman observes, "... we can say

${ }^{69}$ Bloch 1950: 152-153; Hultzsch 1925: 159-164; Mookerji 1928: 193-200, 243-244; Sircar 1967b: 66-67; Thapar 1961: 262. Lamotte interprets this passage to mean that "The king's intention was to reduce dissidents to lay status, by forcing them to return to the white robe of householders" (1988 [1958]: 238).

70 Sasaki, Shizuka. 1989-1999. "Buddhist Sects in the Aśoka Period" (1-8). BukkyōKenkyū 18: 181-202; 21: 157-176; 22: 167-199; 23: 55-100; 24: 165-225; 25 : 29-63; 27: 1-55; 28: 1-10.

${ }^{71}$ Bloch 1950: 154-155; Falk 2006: 106-108, Hultszch 1925: 172-174, Lamotte 1988 [1958]: 234-237, Mookerji 1928: 117-119.

72 Lamotte 1988 [1958]: 235 discusses identifications of Vinaya-samukasa ("Praise of Discipline"), Aliya-vasāni ("Genealogy of the Noble (äryas)"), Anāgata-bhayāni ("Future Dangers"), Munigāthā ("Stanzas of the Sage"), Moneyasüte ("Discourse on Silence"), Upatisa-pasine ("Questions of Upatissa") and Läghulovāde musāvādam ("[Discourse on] Falsehood spoken to Rāhula”). Only three of these identifications (Munigāthā with Suttanipāta vv. 207-221, Moneyasūte with Suttanipāta vv. 699-723, 
that some sort of collection of the Buddhavacana was in existence in Aśoka's time" (1997b: 142). The short individual verse texts selected by Aśoka belong to a very early stratum of Buddhist literature, probably before they were classified into fixed textual categories of nikāyas, àgamas, and pitakas. The significance of Aśoka's recommendation of these texts extends beyond issues of textual classifications and relative chronology, since he explained that his motive for addressing the lay and monastic community was to ensure the durability of the "True Dharma" (Prakrit: sadhamma / Sanskrit: saddharma). His concern about the vulnerability of the Buddha's teachings to decline or disappearance was probably not merely formulaic, but grounded in the turbulent political and religious realities of his age.

Buddhist traditions claim that Aśoka played an active role in the transmission of Buddhism by sending missionaries beyond Mauryan India, but his inscriptions do not provide corroboration. In the 13th Major Rock Edict, Aśoka lists realms of contemporary Hellenistic rulers, neighboring kingdoms, and imperial territories where his prescriptions for Dharma are followed, and grandiloquently claims that his instructions are followed even in places not visited by his envoys. ${ }^{73}$ Even if such exaggerated proclamations were believable at some level (if Aśoka's envoys did reach distant lands), the Dharma that was transmitted would not have been the Dharma taught by Buddhist monks and nuns, but the more general imperial ideology brought by royal Mauryan messengers. Similar reservations apply to another passage in the 5th Major Rock Edict in which Aśoka refers to the appointment of "Dharma Ministers" (dharma-mahāmātras):

They are busy in all sects, establishing Dhamma, increasing the interest in Dhamma, and attending to the welfare and happiness of those who are devoted to Dhamma among the Greeks (Yonas), the Kambojas, the Gandhārans, the Risțhikas, the Pitinikas, and the other peoples of the west. $^{74}$

References to the borderland inhabitants of the northwestern frontiers of the Mauryan empire suggest that the Dharma-mahämātras were

and Upatisa-pasine with Suttanipāta vv. 955-975) are uncertainly agreed upon (Schopen 1997a [1985a]: 24-5).

${ }_{73}$ Thapar 1961: 256.

${ }^{74}$ Translation according to Thapar 1961: 252 (see pp. 156-158 for additional commentary on mahämätras, although viewing these officials as social welfare agents is probably anachronistic). 
Mauryan imperial agents rather than Buddhist missionaries. While it is possible that Buddhist monks and nuns may have accompanied diplomatic missions, the strongest support for such an interaction is not from inscriptions, but from much later accounts in Pāli chronicles attributing the conversion of Sri Lanka to Aśoka's son Mahinda and daughter Sanghamittā. ${ }^{75}$ Although Aśokan Buddhist inscriptions and the remains of Mauryan period stuppas and monasteries generally support his portrayal as an ardent patron of the sangha, the expansion of Buddhism during this period should be attributed to relatively stable political and economic conditions rather than state patronage. ${ }^{76}$

A virtual silence in Brahmanical Sanskrit sources with regard to Aśoka's legacy contrasts sharply with his legendary status in Buddhist literature. Despite Aśoka's undoubtable historical achievements, characters with the name of Aśoka are rarely mentioned in the Mahäbhārata, perhaps in oblique association with demonic asuras. ${ }^{77}$ Although "Buddhism was in the air for the poets of the Mahäbhärata" (Hiltbeitel 2005: 129), there is not a single explicit reference to the Buddha or to the Buddhist tradition. Such omissions of important historical figures and religious ideologies suggest that Aśoka's role was deliberately downplayed because of his support for the Buddhist sangha in the post-Mauryan period, when the core of the Mahäbhärata may have been composed. ${ }^{78}$

${ }^{75}$ Lamotte 1988 [1958]: 297 does not regard Pāli accounts of the initial transmission of Buddhism to Sri Lanka as reliable, but Gombrich 2006: 135-136 believes the accounts of Aśokan missions are more credible. According to Kevin Trainor, there is "solid historical evidence that the basic facts of the mission to Sri Lanka are trustworthy" (1997: 86), but the primary evidence is a Brāhmī inscription marking a stūpa of the Iḍika (Itțhiya) and Mahinda, a common name that is not clearly preserved.

${ }_{76}$ Following Lamotte 1988 [1958]: 215 and Norman 1997b: 129 rather than Gombrich 2006: 136. As Norman observes, "Buddhists appropriated Aśoka for their own use" (1997b: 127).

77 Biardeau, Madeleine. 2002. Le Mahābhārata: Un récit fondateur du brahmanisme et con interprétation. Paris: Éditions du Seuil, 1.112 refers to an asura known as Aśvapati who became an invincible king named Aśoka in Mahābhārata 1.67.13b-15a. Mahäbhärata 12.4.6-8 lists Aśoka among the kings who attended the svayamvara for king Citrāngada's daughter, who was abducted by Duryodhana with the aid of charioteer Karna (Biardeau 2002: 1.112, n. 30, Fitzgerald, James, translator. 2004. The Mahäbhärata. vol. 7 Book 11, The book of women. Book 12, The book of peace, part one. Chicago/London: University of Chicago, 175, and Hiltbeitel, Alf. 2005. "Buddhism and the Mahābhārata: Boundary Dynamics in Textual Practice." In Boundaries, Dynamics and Construction of Traditions in South Asia, ed. Frederico Squarcini. Firenze, Italy: Firenze University Press / Munshiram Manoharlal, 119).

${ }^{78}$ The dating of the Mahäbhärata as a whole remains disputed due to conflicting views about what is considered to be the "core" of the epic narrative as opposed to 
Mahäbhärata scholars have long attempted to find reflections of Aśoka in certain characters and to identify heterodox ideologies expressed in the treatment of Dharma. ${ }^{79}$ Starting with the premise that "...political and religious ideas are profoundly influenced by the events and social trends in which they arise" (1997: 333), Nick Sutton suggests that ideological tensions between Dharma and the use of violence are voiced by "the fictional Yudhișthira representing the historical Aśoka and other kings of similar inclination" (1997: 334). ${ }^{80}$ Sutton argues that their mutual "abhorrence of warfare" (1997: 335) following military conquests in Kalinga and the battle at Kuruksetra illustrate unease with normative Kṣatriya values. James Fitzgerald agrees that a "Double Crisis of Dharma" was precipitated by Aśoka and other rulers who "elevated the world-denying, brahmin criticizing movements to positions of imperial honor equal to or superior to that of the Vedas" (2004: 115). However, Fitzgerald views Yudhișthira not as a representation of Aśoka but as a rebuttal or refutation of his "blithe embrace" (137) of nonviolence, since Yudhișthira and his Pạṇạa brothers and allies justify violent actions to restore Dharma. Thus, the composers of the Mahābhārata in the centuries following Aśoka consciously juxtaposed Yudhisțhira, the ideal Kșatriya ruler who "stands steady in battle," to the Buddhist emperor (cakravartin) and Dharmarajja Aśoka. Alf Hiltbeitel accepts the possibility of polysemic juxtapositions between Yudhișthira and Aśoka, suggests parallels between the Brah-

later additions, which continued at least until the Gupta period. Fitzgerald 2004: xvi, n. 2 argues that the "written Sanskrit text" provoked by Aśoka's "dharma-campaign" was substantially completed during or shortly after the time of the Sungas and Kannvas (between the middle of the 2nd century BCE and the end of the 1st century BCE, although 1st century CE is also possible), with systematic expansions continuing until ca. 400 CE. Hiltbeitel 2005: 113 opts for a more constricted period of composition from about $150 \mathrm{BCE}$ to $0 \mathrm{CE}$. While earlier scholars proposed more cautious estimates between ca. $400 \mathrm{BCE}-400 \mathrm{CE}$, specialists are attempting to define phases of composition in the last two centuries BCE followed by significant interpolations in the 1st-3rd centuries CE, with a final form as late as ca. $500 \mathrm{CE}$.

${ }^{79}$ Hiltbeitel comments that questions about relationships between the Mahābhārata and Buddhism were raised by Adolf Holtzmann, whose 'inversion theory' linked Aśoka with a foreign Buddhist Duryodhana, and, as he puts it, "certain authors are still playing with the same gamepieces" (2005: 108). Biardeau 2002 proposed that the "initial shock" (l'ébranlement initial, 1.103) of Aśoka's embrace of Buddhism led to a Brahmanical reaction (1.113), resulting in an epic "riposte to the Buddhist menace" (1.136). Biardeau elaborated on this hypothesis in her conclusion: "Épopée et Bouddhisme" (2.747-782).

${ }^{80}$ Sutton, Nick. 1997. "Aśoka and Yudhișthira: A Historical Setting for the Ideological Tensions of the Mahābhārata?" Religion 27, 333-341. 
min general Drona and the historical figure of Puṣyamitra Sunga, and notices similarities between the denigration of stūpa (edīka) worship in Mārkandeya's ex eventu prophecies of barbarization and criticisms of religious festivals in Aśokan inscripions. ${ }^{81}$ However, he cautions that "one-to-one readings [such as Yudhisthira as a representation or refutation of Aśoka] may have something persuasive about them without being as singly correct as their proposers propound" (2005: 129). While juxtapositions between Aśoka's interpretation of Dharma and Yudhișthira's reconfiguration of Kșatriya identity have stimulated scholarly interpretations, reading the Mahäbhärata as a response to issues of religious patronage and rivalry during the Mauryan period may circumscribe this complex text too neatly and narrowly. The Mahābhārata may just as likely belong to chronological and historical contexts from the second century BCE through third century CE when Indo-Greek, Saka, and Kușanna rulers established dominion over northern India and Buddhist institutions expanded beyond central nodes and main routes formerly controlled by the Mauryans.

The historical memory of Aśoka as a model royal Buddhist patron persisted far beyond South Asia, but his impact on ancient Indian political history and non-Buddhist religious traditions is difficult to assess. The dynastic succession after Aśoka is vague, and the Mauryan empire disintegrated within fifty years of his death in ca. 230 BCE. ${ }^{82}$ Daśaratha, who may have directly followed Aśoka, donated caves to the Ājīvikas at Nāgārjunī Hill near Barabar and is known in some purānic genealogies, but is not mentioned in Buddhist or Jain sources. ${ }^{83}$ In the Divyāvadāna, Asoka's successor Kuñāla was sent to subdue a revolt in Taxila, where he was blinded as a result of an order issued by Tiṣyarakșitā, the chief queen. ${ }^{84}$ According to this account, Kunāla's son Samprati (who is known in Jain literature as a great patron) then became emperor after Aśoka exhausted the empire's resources by

${ }^{81}$ Hiltbeitel 2005: 113, 126. According to Hiltbeitel, "further reminders of an interface with a Buddhism compounded by mlecchification" (2005: 127) reflect a basic antipathy between Brahmins and heterodox Buddhists. His decoding (following Biardeau 2002: 2.753-758) of Jarāsaṃdha as a representation of Māra (or Aśoka) in juxaposition to Kṛṣna as a figure of Bhakti devotionalism associated with Mathura is less convincing.

${ }^{82}$ Thapar 1961: 182-196.

${ }^{83}$ Falk 2006: 270 ff.; Lamotte 1988 [1958]: 259; Thapar 1961: 186-187.

${ }^{84}$ Lamotte 1988 [1958]: 246-248; Strong 1983: 268-286; Thapar 1961: 185. 
making donations to the Buddhist sangha. ${ }^{85}$ The last Mauryan ruler, according to purānic sources, was Brhadratha, who was overthrown by his Brahmin general Puṣyamitra, the founder of the Sunga dynasty, around 185 BCE. ${ }^{86}$ Historians have attributed the rapid decline of the Mauryas within a span of less than fifty years after Aśoka's death to the impossibility of administering such an immense territitory, a cumbersome bureaucracy, an economic crisis marked my devaluation of Mauryan coinage, Brahmanical reaction to official patronage of Buddhists and other śramanas, and the failure of Aśoka's nonviolent Dharma policy to meet the needs of governance or to fufill Kṣatriya norms. While a completely satisfying explanation can not be offered here, the salient point to note is that political and religious dynamics of the Mauryan period provided a crucial impetus for the expansion of Buddhist institutions, which survived the downfall of the dynasty of the Buddhist tradition's most famous patron.

\section{Migrations, Material Exchanges, and Cross-Cultural Transmission in Northwestern Contact Zones}

Movements of people, materials, languages, symbols, and religious ideas and rituals have had numerous impacts on the northwestern frontier of South Asia, which was never an isolated or static enclave. Multiple itineraries used by exogenous migrants for crossing rivers (particularly the Indus and its tributaries in the Punjab), mountain ranges (such as the Hindu Kush, Pamirs, and Karakorum), and deserts demonstrate that permeable geographical boundaries did not hinder mobility. A brief treatment of much earlier material exchanges and migrations introduces themes of contact and mobility, thus setting the stage for the arrival of various groups in the northwestern borderlands after the collapse of the Mauryans in the early second century BCE. The wide distribution of lower Indus Valley seals and other artifacts from the Persian Gulf to Shortughaï in the Amu Darya/ Oxus River valley in Badakhshan (northeastern Afghanistan) demon-

${ }^{85}$ Lamotte 1988 [1958]: 259-260; Strong 1983: 288-292; Thapar 1961: 187-188.

${ }^{86}$ Lamotte 1988 [1958]: 354-357; in the Divyāvadāna (Strong 1983: 292-294) Pusyamitra belongs to the Mauryan line, but he is remembered as an enemy to the sangha. 
strates long-distance maritime and overland trade connections until ca. 1800 BCE. ${ }^{87}$ Similarities between burial practices associated with the Bactria-Margiana Archeological Complex (BMAC, ca. 2100-1500 $\mathrm{BCE}$ ) and the Gandhara Grave Culture (ca. 1700-1400 BCE) as well as grave sites in Baluchistan suggest a pattern for the movement of Proto-Indo-Aryans from the western Central Asian steppes through the Oxus basin and across the Hindu Kush of central Afghanistan to northwestern South Asia. ${ }^{88}$ Nüristānī languages still spoken in northeastern Afghanistan may also represent vestiges of early migrations, since they belong to a separate linguistic branch of Indo-Aryan that appears to have diverged from archaic forms of Old Indo-Aryan (as preserved in vedic Sanskrit). ${ }^{89}$ References in the Rgveda to rivers and other toponyms located in modern Afghanistan and northwestern Pakistan strongly indicate geographical familiarity with the northwestern subcontinent. ${ }^{90}$ Protohistoric networks of long-distance trade contacts, archeological evidence of migrations between Central Asia and South Asia, and the spread of Indo-Aryan languages are preludes for later historical contexts of Buddhist transmission to the northwestern frontiers of South Asia.

${ }^{87}$ Francfort 1989 : 2.389-421 ; Karttunen, Klaus. 1989. India in Early Greek Literature. Helsinki: Finnish Oriental Society, 11-15.

${ }^{88}$ Mallory, J.K. 2002. "Archaeological models and Asian Indo-Europeans," Proceedings of the British Academy 116 [Sims-Williams 2002], 31, fig. 8; Parpola, Asko. 2002. "From the dialects of Old Indo-Aryan to Proto-Indo-Aryan and Proto-Iranian." Proceedings of the British Academy 116 [Sims-Williams 2002], 66-72. Parpola cautions against using archaeological data to track linguistic change, since the producers of an archaeological culture may speak several languages or may adopt new languages. For a more skeptical view of proposed linkages between archaeological patterns and later texts (Avesta and Rgveda), see Lyonnet, Bertille. 1994. "Central Asia, the IndoAryans and the Iranians: Some reassessments from recent archaeological data." In South Asian Archaeology 1993, eds. Asko Parpola and Petteri Koskikallio. Helsinki: Suomalainen Tiedeakatemia, vol. 1, 425-434.

89 Degener, Almuth. "The Nuristani Languages." Proceedings of the British Academy 116 [Sims-Williams 2002], 103-117 reaches this conclusion following a succinct overview of hypotheses of Nüristānī affiliations with Iranian, Indian (Indo-Aryan), or a separate branch of Old Indo-Iranian (as Georg Morgenstierne proposed). Cardona and Jain 2003: 22-25 also opt for an Indo-Aryan affiliation of Nüristānī.

90 Witzel, Michael. 1987. "On the Localization of Vedic Texts and Schools (Materials on Vedic Sakhas, 7)." In India and the Ancient World: History, Trade, and Culture Before AD 650, ed. Gilbert Pollet. Leuven: Departement Oriëntalistiek), 173-213. 


\section{Iranian Contacts in the Northwest}

Contacts with the Achaemenid empire of ancient Iran and the Hellenistic successors of Alexander of Macedon initiated a series of cross-cultural encounters in the Northwest. Old Persian inscriptions of Darius I (522-486 BCE) and Xerxes (486-465 BCE) indicate that Gandhāra (Gadāra) and Sindh (Hiduš) in present-day northwestern and southern Pakistan were the easternmost Achaemenid provinces. ${ }^{91}$ Relying on the account of Scylax of Caryanda, the Greek historian Herodotus (4.44) briefly refers to an expedition sent by Darius I to explore the Indus River around 518-519 BCE. ${ }^{92}$ This account seems to confirm that the lower Indus valley was included in the domain of Darius I, who received 360 talents of powdered gold in tribute from this province, thus exceeding the amount of revenue from any other province. ${ }^{93}$ Despite these epigraphic and literary references to Achaemenid tributary provinces in India, it is important to acknowledge significant differences between official images and the difficult reality of administering an empire extending from the Mediterranean to the Indus. Pierre Briant wisely cautions:

${ }^{91}$ For editions and translations of Old Persian inscriptions, see Kent, Roland. 1953. Old Persian: Grammar, Texts, Lexicon. 2nd rev. ed. New Haven: American Oriental Society, 116-138, 150-151. Vogelsang, W.J. 1992. The Rise and Organisation of the Achaemenid Empire: The Eastern Iranian Evidence. Leiden: Brill, 94-179 devotes considerable attention to Achaemenid royal inscriptions, Apadāna reliefs, and the Persepolis fortification tablets. Pierre Briant. 2002 [1996]. From Cyrus to Alexander: A History of the Persian Empire, translated by Peter T. Daniels (Histoire de l'Empire perse: de Cyrus à Alexandre. Paris: Fayard). Winona Lake, Indiana: Eisenbrauns, 173 provides a helpful table of "empire lists" in Old Persian inscriptions. References by Herodotus (3.91-94) to the tribute received by Darius from Asia and his account of the expansion of the Achaemenid empire to the east are discussed by Karttunen 1989: 32-38, Parker 2008: 21-28, and Vogelsang 1992: 200-207. Fleming, David. 1993. "Where was Achaemenid India?" Bulletin of the Asia Institute 7, 67-72, suggests that Taxila may have been the capital of the "Indian" satrapy.

92 Briant 2002 [1996]: 140, 904; Karttunen 1989: 40-48, 65-68; Parker 2008: $14-18$.

${ }^{93}$ Herodotus (3.94-95) calculates that 360 talents of gold-dust annually received by Darius from the twentieth satrapy of India (the lower Indus) is equivalent to 4680 silver talents, since gold is worth thirteen times the value of silver. The story relayed by Herodotus $(3.98,102-105)$ of how the Indians acquired such a large supply of gold by using great ants "in size somewhat less than dogs, but bigger than foxes" (Rawlinson, George, trans. 1942. The Persian Wars. New York: Random House, 262) raises suspicions about the credibility of this figure. Tarn 1985 [1951]: 108 dismisses the story, but Karttunen 1989: 37-38, 171-176 discusses possible sources for the story of the golddigging ants and points out that the source of the gold was not the lower Indus. 
It appears clear that neither the country lists nor the depictions of peoples are intended to give a realistic picture of the administration or the geography of the Empire. Instead, the lists and depictions are primarily the vehicles of the very idea of royal and imperial power. (Briant 2002 [1996]: 183)

The extent of direct Achaemenid control over the northwestern Indian subcontinent remains unclear, especially in regard to Taxila and areas east of the Indus River.

Fragmentary accounts of the Persika and Indika attributed to Ctesias of Knidos, a Greek physician who served in the Achaemenid court for sixteen or seventeen years until 398/7 BCE, illustrate how fantastic and factual information about India was filtered to a Greek audience through Iran. ${ }^{94}$ Unfortunately, Ctesias' account of the Achaemenid network of routes across the Iranian plateau and western Central Asia to the Indian subcontinent has not survived, since the 'Royal Road' between Sardis and Susa described by Herodotus (5.52-4) was "just one royal road among many others" (Briant 2002 [1996]: 357). ${ }^{95}$ As Pierre Briant comments, "...many other itineraries, often much shorter and often following mountain or desert routes, are left out" and "It was in fact impossible to travel by such routes without local guides" (2002 [1996]: 360). While official documents indicate that the main roads primarily served political and military purposes, Briant observes that "information on customs and tolls seems to confirm the breadth and density of trade" (387).

Cross-cultural borrowings from Achaemenid Iran were certainly possible, but Indian sources do not explicitly refer to transmission

${ }_{94}$ Karttunen 1989: 80-85 discuses the "bad reputation" (80) of Ctesias among classical authors and modern scholars, but cautions that "we cannot always use modern criteria when judging ancient authors" (81). Karttunen's observation that authors like Herodotus and Megasthenes who are viewed as (relatively) more trustworthy were also "fond of marvels" (82) is contested by Parker, who argues that "The marvel, so important to Ctesias' ethnography with its tendencies towards natural history, became an embarrassment to the development of a new kind of historiography that was beginning to emerge" (30-31). Parker reviews current scholarship, including a commentary on fragments attributed to Ctesias by Lenfant, Dominique. 2004. La Perse; l'Inde; autres fragments. Collection des universités de France, v. 435. Paris: Belles lettres. Now also see Nichols, Andrew. 2008. The Complete Fragments of Ctesias of Cnidus: Translation and commentary with an introduction. Gainesville: University of Florida Ph.D. Dissertation.

${ }_{95}$ According to Photius' summary, the Persika of Ctesias "described the relays (stathmoi), days elapsed, and parasangs between Ephesus and Bactria and India" (Briant 2002 [1996]: 357). 
in either direction. The derivation of the Kharoșthi script from Aramaic, which was used throughout the Achaemenid realm, is relatively straightforward, but the development of Brāhmī as a chancellery script for writing Aśokan inscriptions may have also been related to an effort to emulate the royal inscriptions of Achaemenid or later Seleukid rulers. ${ }^{96}$ Achaemenid influences on Mauryan art and architecture have also been suggested, but the evidence for this period of Indian art is very limited. ${ }^{97}$ The possibility of Iranian influences on later layers of rock art in the Upper Indus valley is stronger, but Achaemenid sources seem unlikely. Nevertheless, the long period of Achaemenid control (however nominal) of the northwestern borderlands prior to the conquests of Alexander of Macedon is likely to have enhanced its already hybrid Indo-Iranian culture by opening additional channels of trade, travel and communication.

\section{Hellenistic Interactions}

Alexander's attempt to invade India initiated cross-cultural interactions between Hellenistic and South Asian civilizations in the contact zones between the Indus and Oxus rivers. After conquering the Achaemenid heartland of ancient Iran following the battle of Gaugamela in $331 \mathrm{BCE}$, Alexander of Macedon led a large military expedition to Central Asia (Bactria and Sogdia) and the northwestern regions of South Asia (Gandhāra, Punjab, and the lower Indus) between 330-325 BCE. ${ }^{98}$ Since he retreated down the Indus River following a difficult expedition rather than pursing further conquests in the Indian subcontinent, the question of whether he intended to subdue only the eastern borderlands of the Achaemenid empire or to complete a world

\footnotetext{
${ }^{96}$ Falk 1993: 92-104, 337-340; Salomon 1998a: 28-30, 51-54; Salomon 2003a: 88, 92-93.

97 Thapar 1961: 129, 266-270.

98 Alexander's campaigns in Central Asia and South Asia have received considerable attention. For Central Asian campaigns, see Holt, Frank. 1989. Alexander the Great and Bactria: The Formation of a Greek Frontier in Central Asia. Leiden: Brill. Karttunen 1997a: 19-54 discusses the significance of Alexander's campaigns in South Asia. Both authors address western classical literary sources for the history of Alexander and issues of modern historiography, especially the contrast between the views of Tarn 1984 [1951] and Narain, A.K. 1957. The Indo-Greeks. Oxford: Clarendon [reprint, Delhi: Oxford University Press, 1980].
} 


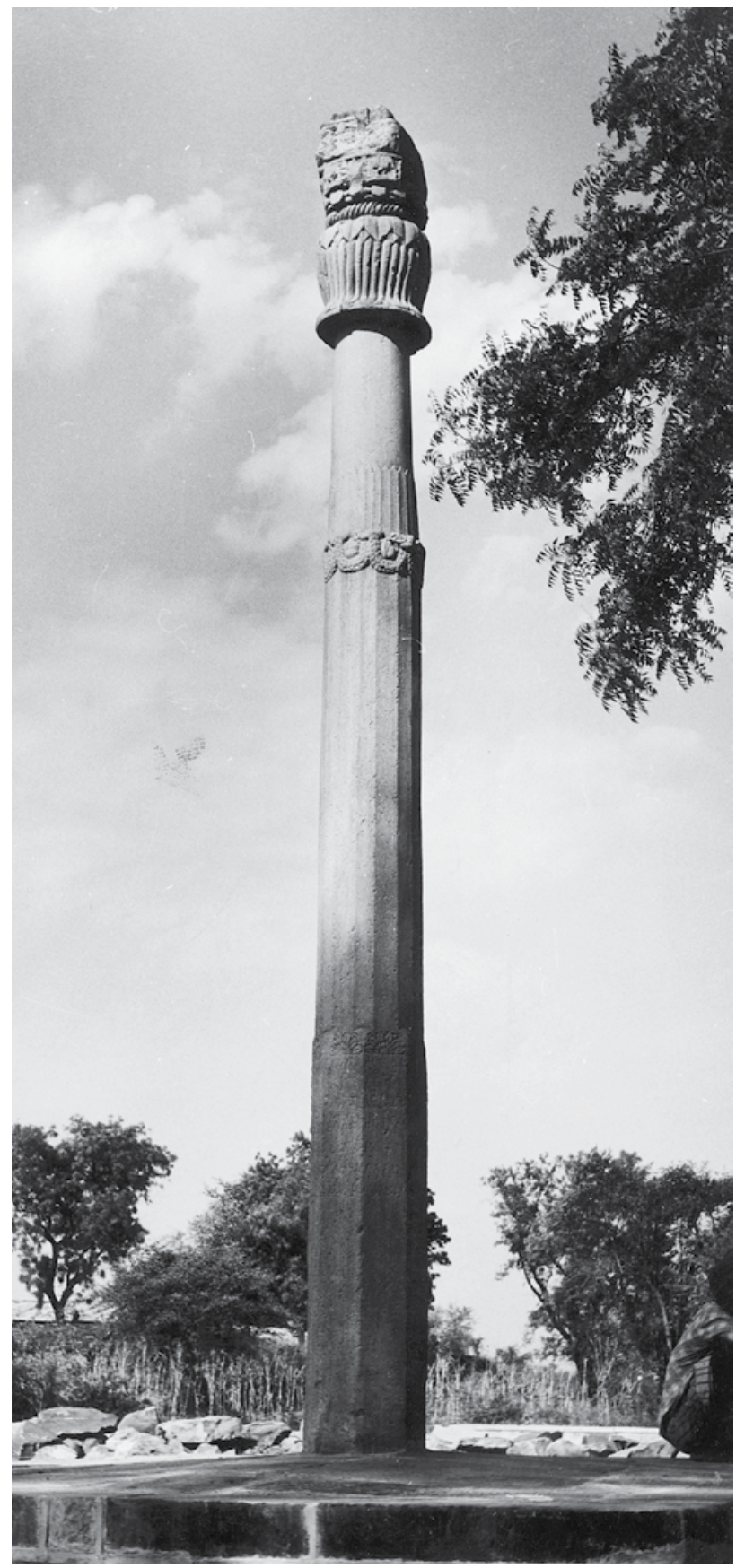

Fig. 2.1: Heliodoros Pillar in Vidiśā (courtesy of the American Institute of Indian Studies). 
conquest remains open to debate. ${ }^{99}$ Along the way, he established garrisons at important nodes where Greek colonists maintained Hellenistic cultural and religious ties long after his death in Babylon in 323 BCE. ${ }^{100}$ Although localizations of eponymous "Alexandrias" and other cities purportedly founded during his South Asian campaigns are uncertain, relatively recent discoveries of archaeological evidence from Kandahar (Alexandria in Arachosia) and Ai Khanum confirm the survival of Hellenistic cultural life in border areas of South Asia. ${ }^{101}$ In addition to Greek and Aramaic inscriptions of Aśoka in Kandahar (discussed previously), a second century BCE Greek epitaph from the family tomb of a trader named Sophytos, the son of Naratos, indicates that Hellenistic literary culture continued to be cultivated:

For a long time the house of my forefathers was flourishing when the irresistible fury of the Three Fates destroyed it. I, unfortunate Sophytos, scion of the family of Naratos, quite young and deprived of the wealth of my family, who had cultivated the arts of Apollo the archer and the Muses together with the virtue of wisdom, considered how to restore my ancestors' house to a new grandeur. Having borrowed money to make it fructify, I left my country, determined not to return before amassing a great fortune. Therefore, I took up commerce in many cities. I accumulated great wealth without suffering any harm. Here I am, having returned after innumerable years to my fatherland, with much praise and amidst my friends' rejoicing. And at one and the same time, I have reconsctructed and beautified my ancestors' house, which was dilapidated, and since the family tomb had fallen to the ground, I rebuilt a new one. And I had this stele erected next to the road so that it will speak thus: look at my accomplishements. Well worthy to be imitated. May my sons and grandsons preserve the house which they owe to me. ${ }^{102}$

${ }^{99}$ In assessing the legacy of Alexander in Asia, Holt emphasizes that "We might avoid preconceptions about Alexander's personality and impact by asking what the king did rather than dreamt..." (1989: 8). Foucher, Alfred. 1942-1947. La vieille route de l'Inde de Bactres á Taxila. 2 vols. Paris: Éditions d'art et d'histoire, argued that Alexander "would do no more than place his feet in the imprints left by Cyrus and Darius I" (2.191).

${ }^{100}$ For identifications of cities reportedly founded by Alexander, see Karttunen1997a: 46-54 and Rapin, Claude. 2005. "L'Afghanistan et l'Asie Centrale dans la géographie mythique des historiens d'Alexandre et dans la toponymie des géographes gréco-romains." In Afghanistan: Ancien carrefour entre l'est et l'ouest, eds. Osmund Bopearachchi and Marie-Françoise Boussac. Turnhout, Belgium: Brepols, 143-172.

${ }_{101}$ Ghosh, Suchandra. Forthcoming. "In Search of Hellenism at Ai Khanum and Kandahar." In Revisiting Early India through Epigraphy and Other Texts. Essays in memory of D.C. Sircar, ed. Suchandra Ghosh et al. Calcutta.

102 Bernard, Paul, Georges-Jean Pinault, and Georges Rougemont. 2004. "Deux nouvelles inscriptions grecques de l'Asie centrale." Journal des savants, 227-356. Rougemont, Georges. 2005. "Nouvelles inscriptions grecques de l'Asie centrale." In Bope- 
This inscribed stele shows that Indian merchants like Sophytos, whose name is probably equivalent to Subhūti and whose father's name may be derived from Nārada in Sanskrit, adapted Greek religious practices and philosophical outlooks while "amassing great fortune" through "commerce in many cities." 103

Hellenistic culture also flourished at Ai Khanum, "a full Greek polis" (Karttunen 1997a: 47) located at the confluence of the Oxus and Kokcha rivers in northeastern Afghanistan. Excavations by the French Archaeological Mission in Afghanistan between 1965-1978 revealed Greek and Iranian temples, a gymnasium, a theatre, an arsenal, and a palace, as well as Greek dedicatory and funerary inscriptions and copies of Delphic maxims set up by Clearchus of Soli. ${ }^{104}$ Archaeological, epigraphic, and numismatic evidence for the presence of Greek colonists and Hellenized local inhabitants at Ai Khanum (until its abandonment around $145 \mathrm{BCE}$ ) demonstrates that long-distance contacts and exchanges between the Mediterranean, Iranian, and Indian worlds continued long after the period of Alexander's expedition. Although Alexander was not remembered in ancient South Asian sources, recent discoveries associated with his successors who adapted to dynamic political, economic, and religious conditions in borderland outposts challenge the earlier assessments of W.W. Tarn and A.K. Narain, who juxtaposed imperialistic Greeks to proto-nationalistic Indians. ${ }^{105}$

arachchi and Boussac 2005: 127-136. I am grateful to Suchandra Ghosh for sharing her English translation, which is adopted here with minimal modifications.

${ }^{103}$ For onomastic analysis, see Pinault's contribution to Bernard, et al. 2004: 249259 and Pinault, Georges-Jean. 2005. "Remarques sur les noms propres d'origine indienne dans le stèle de Sôphytos." In Bopearachchi and Boussac 2005: 137-142. According to Rougemont (2004: 240-241, 2005: 131), the phrase "I took up commerce in many cities" recalls the 3rd verse of Homer's Odyssey, reflecting a widely invoked topos of the itinerant life in funerary poems across the Hellenistic world.

${ }_{104}$ Bernard, Paul et al. 1973-1992. Fouilles d'Aï Khanoum I-VIII. Mémoires de la Délégation Archéologique Française en Afghanistan 21, 26-31, 33. Paris: Klincksieck. For succinct English overviews, see Bernard, Paul. 1967. Aï Khanum on the Oxus: $a$ Hellenistic city in central Asia. Albert Reckitt archaeological lecture, 1967. London: Oxford University Press (= Proceedings of the British Academy 53 [1967], 71-95), Bernard, Paul. 1982. "An Ancient Greek City in Central Asia." Scientific American 246, 148-159 and Bernard 1994b: 88-129. The archaeological site of Ai Khanum has been devastated by looting, but objects from the National Museum in Kabul have been displayed in an international exhibition (Bernard, Paul. 2008. "The Greek colony at Ai Khanum and Hellenism in Central Asia." In Hiebert, Fredrik T. and Pierre Cambon, eds. Afghanistan: Hidden Treasures from the National Museum, Kabul. Washington, D.C.: National Geographic, 81-129.)

${ }_{105}$ Tarn unfavorably compared the military impact of Alexander's expedition to his Achaemenid predecessors: "His success was far more evanescent than that of Darius; a few years after his death the only traces left of his rule, not counting the Paropamisadae 
From around $250 \mathrm{BCE}$ until the late first century BCE, Bactrian and Indo-Greek kings successfully established control of regional domains while struggling to defend against Sakas and other groups migrating across Central Asia. ${ }^{106}$ Their dynastic history is mostly reconstructed through numismatic analysis of widely distributed coinage, which along with other forms of material evidence reflects a synthesis of Greek, Indian and Iranian languages and writing systems, political titles, religious symbols, and artistic styles. ${ }^{107}$ For example, Agathokles, an Indo-Greek ruler around 190-180 BCE, issued a special series of silver coins with the earliest attested images of Kṛṇa-Vāsudeva and his brother Balarāma-Samkarșana, and another series of bronze coins with either Subhadrā, their sister, or Lakșmī, the Indian goddess of wealth and fortune. ${ }^{108}$ Osmund Bopearachchi (1993: 23) suggests that

[Achaemenid Gandhāra], were two or three of the cities he had founded, islands now in an Indian sea" (1984 [1951]: 130). A.K. Narain, held that the impact of Alexander's successors was very limited: "Their history is part of the history of India and not of the Hellenistic states; they came, they saw, but India conquered" (1957: 11).

${ }^{106}$ Holt, Frank. 1999. Thundering Zeus: The Making of Hellenistic Bactria. Berkeley: University of California Press integrates archaeological, numismatic and literary sources to reconstruct the history of the Bactrian Greeks. Karttunen 1997a: 277 provides a helpful chart of different chronologies for the end of Indo-Greek rule following a succinct treatment of classical western literary sources. Saka and Kușāna migrations and conflicts with the Bactrian Greeks are discussed in the following section (pp. 109-145).

${ }_{107}$ Since earlier studies by Tarn and Narain, numismatic analysis by Osmund Bopearachchi has made significant progress in clarifying relative chronologies of Bactrian Greek and Indo-Greek rulers: Bopearachchi, Osmund. 1991. Monnaies gréco-bactriennes et indo-grecques: catalogue raisonné. Paris: Bibliothèque nationale; Bopearachchi, Osmund. 1993. Indo-Greek, Indo-Scythian and Indo-Parthian coins in the Smithsonian Institution. Washington: National Numismatic Collection, Smithsonian Institution; Bopearachchi, Osmund, and Aman Ur Rahman. 1995. Pre-Kushana coins in Pakistan. Karachi (Pakistan): Mughal Print. \& packaging (Pvt) Ltd; Bopearachchi, Osmund. 1998. "Foreign Powers in Ancient Northern India from the Bactrian Greeks until the time of the Early Kushans." Part 2 of Bopearachchi, Osmund and Wilfried Pieper. 1998. Ancient Indian coins. Turnhout: Brepols, 177-273. Recent updates and alternative chronologies are summarized by Cribb, Joe. 2005. "The Greek kingdom of Bactria, its coinage and its collapse." In Bopearachchi and Boussac 2005: 207-225 and MacDowall, David. 2007a. "Numismatic Evidence for a Chronological Framework for Pre-Kaniṣkan Art, from Kalchayan to Gandhāra.” In Srinivasan 2007: 95-117. Errington and Cribb 1992 provide many excellent illustrations of cross-cultural exchanges and assimilation between the Indo-Greeks, Iranians, and Indians in the "Crossroads of Asia."

${ }^{108}$ Bopearachchi 1991: 172-180; Bopearachchi 1993: 23; Errington and Cribb 1992: 62. Holt comments that Agathokles "was a man of two worlds, a scion of east and west" (1989: 1). According to Ghosh, Suchandra. 2007. "Understanding Transitions at the Crossroads of Asia: c. Mid Second Century BCE to c. Third Century CE" Studies in History 23.2, 289-310, the images on these coins are "...the oldest depiction[s] of Indian deities that we have, and as such are symbolic of an intermingling of Hellenistic with Indian cultures" (2007: 304, fig. 4). 
these coins of Agathokles with legends written in Greek, Brāhmī and Kharoșthi may have been issued for the Indian territories where he had only recently proclaimed himself king. Although his predecessor Demetrius is usually regarded as the first Greek ruler to have made conquests south of the Hindu Kush, ${ }^{109}$ on the basis of a recent discovery of a Kharoșthi inscription dated in year 201 "of the Greeks" (yonana) and year 73 of the Azes era beginning in 58/7 BCE, Richard Salomon argues that Agathokles may have been responsible for initiating an "Indo-Greek era" in 186/5 BCE. ${ }^{110}$ In addition to instituting the first continuous historical era, the Indo-Greek rulers also left imprints in the form of military and political titles, Macedonian month names used in epigraphical dating formulae, and the use of the Greek alphabet for writing the Bactrian language. Contact and exchange was generally limited to the northwestern frontiers, where layers of Hellenistic influence persisted after the last Indo-Greek rulers disappeared from the political scene in the first century BCE.

The presence of Indo-Greeks in the Northwest during the last two centuries BCE has stimulated debates about their responses to religious and cultural features of the Indo-Iranian borderland environment. Although many deities depicted on their coins belonged to the Hellenistic pantheon, Indo-Greek rulers from Agathokles onwards (as well as Sakas, Parthians, and Kușāṇas) adopted a wide range of Iranian and Indian deities, Buddhist symbols, and South Asian titles and

109 Karttunen 1997a: 273-4 discusses the extent of the Indian domains of Demetrius based on literary references, which also associate Greek conquests of India after Alexander with Apollodotus and Menander. A recently discovered Greek inscription of Heliodotus (Bernard, et al. 2004: 333 ff.; Rougemont 2005: 133-4, fig. 2) from Kuliab in Tajikistan recording a dedication to Hestia refers to Demetrius as a "glorious victor" (kallinikos is a laudative epithet) and to his father Euthydemos as "the greatest of all kings" but does not indicate that their dominion extended beyond ancient Bactria. MacDowall, David. 2005. "The Role of Demetrius in Arachosia and the Kabul Valley." In Bopearachchi and Boussac 2005: 197-206 focuses on the silver and copper coins of Demetrius (also see MacDowall 2007: 99).

110 Salomon, Richard. 2005a. "The Indo-Greek Era of 186/5 BC in a Buddhist Reliquary Inscription.” In Bopearachchi and Boussac 2005: 359-401 (CKI 405: http:// www.ebmp.org/a_inscription.php?catid=CKI0405). Salomon discusses other Brāhmī, Kharosthī, and Bactrian inscriptions that may be dated in this era, which is explicitly attested in a Brāhmī inscription in year 116 "of the reign of the Yavanas" (yavanarajyasya), which would correspond to ca. 70 BCE. Jakobsson, Jens. 2009. "Who Founded the Indo-Greek Era of 186/5 BCE?” Classical Quarterly 59.2, 505-510 speculates that the era may have been promoted by Menander and Antimachus II. I have not yet seen an article by Widemann, François. 2004. "Une confirmation numismatique de l'era yavana de 186/5." Nomismatika Chronika 23, 37-45. 
epithets. ${ }^{111}$ W.W. Tarn attempted to explain Indo-Greek patronage of Buddhism as a strategy to gain local support against Indian rulers such as Pusyamitra, who seized power after the collapse of the Mauryans and restored Brahmanical institutions, according to Sanskrit purānic traditions. ${ }^{12}$ Such a juxtaposition between foreign Greek supporters of Buddhism in the Northwest and traditional Indian kings who maintained "Hindu" orthodoxy oversimplifies more complex patterns of religious patronage of multiple South Asian religious traditions.

Greek patronage of Buddhism is most clearly associated with Menander, a powerful Indo-Greek ruler of the Punjab and northwestern India around 150 BCE who issued numerous coins and is known in both Buddhist and western classical literary traditions. ${ }^{113}$ However, Menander's silver coins showing Athena in various martial poses do not indicate a Buddhist affiliation and his bronze coins depict an eclec-

${ }^{111}$ Karttunen 1997a: 309-315 discusses the representation and localization of Greek gods and the representation of local gods in Greek form. In "The Greek Kingdoms of Central Asia" (in Harmatta 1994: 98-129), Paul Bernard observes that "With very few exceptions, the official state pantheon was entirely Greek" (1994b: 114), but temples dedicated to local and Iranian deities at Ai Khanum "owed nothing to Greek tradition" (ibid., 115). Bernard ameliorates this apparent discrepancy between numismatic iconography and religious architecture, archaeology and art by commenting that "the Greeks themselves had probably never, except in their own official state religion, put up any barriers between their own gods and those of their subjects, and so had paved the way to their progressive assimilation" (127). MacDowall, David. 2007b. "Coinage from Iran to Gandhāra-with special reference to divinities as coin types." In Srinivasan 2007: 233-266 surveys deities depicted on Bactrian, Indo-Greek, Indo-Scythian, and Indo-Parthian coins.

112 Although Narain 1957: 98-9 effectively counters Tarn 1984 [1951]: 175, similar arguments are adopted by Lamotte 1988 [1958]: 385 and Seldeslachts, Erik. 2007. "Greece, the Final Frontier? The Westward Spread of Buddhism." In Heirman and Bumbacher 2007: 131-166, who writes that "The Greek struggle with Pusyamitra gave the Buddhists the prospect of renewed influence... What may be sensed is that strategic reasons made some Greeks the promoters of Buddhism and some Buddhists supporters of the Greeks" (141).

${ }_{113}$ Bopearachchi, Osmund. 1990. "Ménandre Sôter, un roi Indo-grec. Observations chronologiques et géographiques." Studia Iranica 19, 39-85 and Fussman, Gérard. 1993a. "L'Indo-grec Ménandre ou Paul Demiéville revisité." Journal Asiatique 231, 61-138 make important corrections to views offered by Foucher 1947: 273-276, Lamotte 1988 [1958]: 420-426, Narain 1957: 74-100, and Tarn 1984 [1951]: 225-269. A fragmentary Kharosthī inscription on the lid of a Buddhist reliquary casket from Shinkot in Bajaur dedicated by the Aprajaraja Vijayamitra in the mid-late first century BCE may refer to an era of "Mahārāja Menander" (minedrasa maharajasa) (CKI 176: http://www.ebmp.org/a_inscription.php?catid=CKI0176). Falk, Harry. 2005. "The Introduction of Stūpa-worship in Bajaur." In Bopearachchi and Boussac 2005: $347-358$ argues that this part of the inscription is not genuine (351-2, fig. 4), but it seems unlikely to have been a forgery. 
tic mixture of ambiguous symbols, including the wheel which could be associated with a wheel-turning emperor (cakravartin) or the wheel of dharma (dharmacakra). ${ }^{114}$ In contrast to the numismatic evidence, Pāli and Chinese Buddhist texts invariably portray Menander as an important Buddhist patron. ${ }^{115}$ In shorter and earlier versions, Menander is satisfied with the responses of the learned monk Nāgasena and donates an expensive wool blanket and 800 meals to the Buddhist community, but it is only in the expanded Pāli version that Menander (Milinda) relinquishes his throne, converts to Buddhism, and becomes a lay follower (upāsaka). ${ }^{116}$ Although the Moralia of Plutarch refer to the distribution of Menander's relics (mnēmeia), such burial practices are more likely to be connected with Hellenistic hero cults than Buddhist worship of the relics of a lay patron. ${ }^{117}$ Thus, Buddhist literary traditions

114 Bopearachchi 1990: 48 and Fussman 1993a: 85-90 agree that the numismatic evidence does not confirm Menander's conversion to Buddhism, but comments by Paul Bernard (see note 110) on discrepancies between the official state pantheon and religious architecture and archaeology may help to reconcile differences between depictions of deities on Menander's coinage and his reputation as a Buddhist patron in Buddhist literary traditions.

${ }^{115}$ Fussman 1993: 66-82 and Lamotte 1988 [1958]: 423-426 largely base their comparisons of Pāli and Chinese literary traditions of dialogues between Menander and Nāgasena on Demiéville, Paul. 1924. "Les versions chinoises du Milindapañha." Bulletin de l'École Française d'Extrême Orient 24, 1-264. According to Demiéville, an earlier version was translated into Chinese (Taishō 1670: "Sūtra of the Bhikșu Nāgasena") from a middle Indic version between 317-420 CE, and a short synopsis of dialogues between Nāgasena and Menander is included among avadānas compiled in the Za bao zang jing (Taishō 203, chapter 9, 492c-493b) by T'an-yao in $472 \mathrm{CE}$ (Willemen, Charles, trans. 1994. The Storehouse of Sundry Valuables. Berkeley, CA: Numata Center for Buddhist Translation \& Research, 224-227). The later expansion (with an additional four chapters) of the 5th century CE Pāli version of the Milindapañha (Trenckner, V., ed. 1880. The Milindapañho: Being dialogues between King Milinda and the Buddhist sage Nägasena. London: Williams Norgate) has frequently been translated into English: Rhys Davids, T.W. 1890-1894. The Questions of King Milinda. Pts. 1-2. Oxford: Clarendon Press; and Horner, I.B. 1963. Milinda's Questions. 2 vols. London: Luzac. Additional references to the paracanonical Pāli text and commentary are compiled by Hinüber 1996: 82-6, \$172-180, who observes that "although Milinda is Greek, there is not traceable Greek influence on form or content..." (1996: 83).

116 Fussman, Gérard. 1994a. "Upāya-kauśalya: L'implantation du bouddhisme au Gandhāra." In Bouddhisme et cultures locales: Quelques cas de réciproques adaptations, eds. Fukui Fumimasa and Gérard Fussman. Paris: École Française d'Extrême Orient, 25-26 remarks that Menander's conversion to Buddhism and assumption of upāsaka status should be understood only in the sense that he was not hostile to Buddhism, since aside from the Milindapañha's version, there is no other indication that affirms his exclusive preference for Buddhism.

117 References to Menander in Plutarch's Moralia (821 D-E) are discussed by Fussman 1993a: 65 and Lamotte 1988 [1958]: 421. According to Burkert, Walter. 1985 [1977]. Greek Religion. Translated by John Raffan. Cambridge: Harvard University 
adopt Menander "as one of theirs" (Lamotte 1988 [1958]: 425) but do not prove that he was exclusively Buddhist, since he probably supported a wide array of religious groups seeking his support, just like any other South Asian ruler.

In adopting South Asian models of religious patronage, the distinctive identity of the Indo-Greeks eventually disappeared as they became fully Indianized. While King Menander is praised as a Buddhist patron (if not a convert), a Greek ambassador (yonadūta) named Hēliodōros sent from Taxila to Vidiśā in central India by the IndoGreek king Antialkidas, refers to himself as a devotee (bhägavata) of Viṣnu in a late second century BCE Brāhmī inscription (fig. 2.1: Heliodoros Pillar). ${ }^{118}$ Hēliodōros donated a pillar of Garuda, the eagle who serves as Viṣnu's animal emblem, during his visit to the court of Kāśīputra Bhāgabhadra, whom historians have attempted to identify with Sunga kings listed in purānicic genealogies such as Bhadraka/ Odraka or Bhāga(-vata). ${ }^{119}$ Some Greek names and titles also appear in Buddhist inscriptions from the Northwest and in Buddhist cave inscriptions from western India. ${ }^{120}$ However, references to Yavana (or

Press, "A hero cult involves setting apart one particular grave, known as a heroon, from other burials by marking off a special precinct, by bringing sacrifices and votive gifts, and occasionally by building a special grave monument" (1985: 203). Burkert's comments about connections between the rise and popularity of hero cults during Hellenistic times and the establishment of "effectice presence" in a "specific locality" suggest structural resonances with Buddhist relic cults that may have appealed to a Greek audience in the Northwest.

118 Salomon 1998a: 265-267 (Appendix 2: Besnagar Pillar Inscription of Hēliodōros, fig. 12, with further references on p. 266).

${ }_{119}$ Sircar, Dineschandra. 1965. Select Inscriptions bearing on Indian History and Civilization. Vol. 1: From the Sixth Century BC to the Sixth Century AD 2nd ed. Calcutta: University of Calcutta, 88-89 suggests that "Bhāgabhadra may be identified with Bhadraka, the fifth Sunga king according to the Bhägavata Puräna (88, n. 4). However, this identification is dismissed by Narain 1957: 119, who instead identifies Bhāgabhadra with the ninth Śunga king known as Bhāga or Bhāgavata. A Śunga connetion remains hypothetical, since Kāśiputra Bhāgabhadra may have been a local or regional ruler of Vidiśā.

${ }_{120}$ Fussman 1994a: 26 points out that only the Kharoșţi inscription of the Meridarch Theodoros may belong to the period of the Indo-Greek rulers in the Northwest, although other Greek names appear in later inscriptions. Since very few Kharoșthi inscriptions (with the exception of the Aśokan edicts) can be dated before ca. $50 \mathrm{BC}$, it would be misleading to conclude that "This lack of information on the Greeks in the inscriptions of Gandhāra and Panjab seems to indicate that there was no noticeable Greek influence on Buddhism..." (Dietz, Siglinde. 2007. "Buddhism in Gandhāra." In Heirman and Bumbacher 2007: 56). For Yavanas in western Indian inscriptions, see Karttunen 1997a: 297-298, who refers to hypotheses for associating them with merchants advanced by Stein, Otto. 1935. "Yavanas in early Indian inscriptions." Indian 
Yona) donors with Indian and Iranian names do not strictly designate Greek descendants, since "...the connotation of Yavana underwent changes from being identified as Greek to Graeco-Iranian, Hellenist Indian, Indianized Greek, and Graeco-Roman or anyone coming from the West" (Ghosh 2007: 291).

Alfred Foucher strongly advocated for the importance of an amalgamation of Hellenistic models with Indian and Iranian traditions in the Buddhist art of Gandhāra. ${ }^{121}$ However, Foucher's theory of a "Graeco-Buddhist" school of art and his arguments for a Greek origin of anthropomorphic images of the Buddha remain controversial. ${ }^{122}$ Foucher and other proponents of Hellenistic influences in Gandhāran Buddhist art have struggled to explain a chronological gap between the heyday of Indo-Greek rule in the Northwest in the second century BCE and the first appearance of identifiable Hellenistic features in Buddhist art of Gandhāra only in the first century CE. ${ }^{123}$ Lamotte, for example, acknowledged that "...this influence took a long time to become apparent and that although it was implanted during the IndoGreek occupation, it did not bear fruit until first the Saka-Pahlava period, and then the Kușanana" (1988 [1958]: 429). This problematic lag between the hypothetical 'implantation' and concrete 'manifestation' of a proposed Hellenistic 'synthesis' in Gandhāran Buddhist art raises questions about the impetus, extent, and significance of the long survival of Greek stylistic features, which were transmitted through numerous intermediaries and are more related to technical

Culture 1, 343-357 (= Stein, Otto. 1985. Kleine Schriften. Ed. F. Wilhelm, GlasenappStiftung 25. Stuttgart: Steiner Verlag Wiesbaden, 351-365).

${ }^{121}$ Foucher, Alfred. 1905-1951. L'art gréco-bouddhique du Gandhâra; étude sur les origines de l'influence classique dans l'art bouddhique de l'Inde et de l'Extrême-Orient. Paris: E. Leroux. 3 vols.; Foucher 1947: 306-354.

${ }_{122}$ Art historical debates provoked by Foucher are succinctly treated by Zwalf, Wladimir. 1996. A Catalogue of the Gandhära Sculpture in the British Museum. London: British Museum, 67-76. For very different assessments of Foucher's legacy, see Abe, Stanley. 1995. "Inside the Wonder House: Buddhist Art and the West." In Lopez 1995b, 75-84, Olivier-Utard, Françoise. 2003 [1997]. Politique et Archéologie: Histoire de la Délégation archéologique française en Afghanistan, 1922-1982. 2nd ed. Paris: Éditions Recherche sur les Civilisations, 29-81, and Nehru, Lolita. 1989. Origins of the Gandhäran Style: A Study of Contributory Influences. Delhi: Oxford University Press.

${ }^{123}$ Foucher posited that Hellenism lay dormant in Gandhāra until a combination of factors including the expansion of Buddhism and increasing commerce led to a "rebirth of influence under the Indianized form" (1947: 324) when "the Hellenistic seed bore its fruits under a dynasty not very different from that which implanted it" (1947: 333). Fussman 1994a: 26 points out that the period of Buddhism's success in Gandhāra is either contemporary with or posterior to the downfall of the Indo-Greek rulers. 
detail rather than religious ideology. ${ }^{124}$ Maurizio Taddei identified Hellenistic models and narrative motifs in Gandhāran Buddhist art and architecture, but recognized that these foreign elements were appropriated from a wide range of Hellenized cultures extending from the Mediterranean to Egypt, Parthia, and Gandhāra, where local and exogenous groups chose to adopt, preserve, and innovatively develop distinctive styles of art and iconography. ${ }^{125}$ Since Italian excavations of an Indo-Greek urban center at Barikot in the Swat valley of northwestern Pakistan have revealed "the undeniable presence of workshops and craftsmen of Hellenistic tradition active in the Northwest" (Callieri 2007: 158), ${ }^{126}$ Hellenistic ateliers may have continued to contribute to the mélange of iconographic elements and architectural styles evident in Gandhäran Buddhist art in the early centuries CE.

Relationships between Iranian and Hellenistic cultures and the Buddhist traditions of Gandhāra and Central Asia are addressed further in Old Roads in the Northwestern Borderlands (Chapter 4) and Long-Distance Transmission to Central Asian Silk Routes and China (Chapter 6). A tendency of many earlier scholars such as Foucher and Lamotte to overemphasize the impact of the Achaemenids and Indo-Greeks on the history of Buddhism has been counterbalanced by efforts to downplay 'foreign' influence. Interactions between Brahmins who were already well established in the region since vedic times, Buddhist newcomers, socially assimilated exogenous migrant groups, and local intermediaries (like Sophytos) who appropriated Iranian and Greek languages, writing systems, titles, customs, and ideas for their own political and economic benefit contributed to dynamic hybridity. ${ }^{127}$

${ }^{124}$ Fussman, while accepting the possibility of a "synthèse hellénico-Bouddhique" (1994a: 27) long after the end of Indo-Greek political domination, argues that the artistic traditions of Gandhāran Buddhism are ideologically identical to those of Mathura and Amarāvatī.

${ }_{125}$ Taddei, Maurizio. 2003. On Gandhāra: Collected articles, ed. Giovanni Verardi and Anna Filigenzi. Napoli: [M. D'Auria?] includes Taddei's studies and reviews of Gandhāran art history, archaeology, and cultural history published over a span of 40 years.

${ }^{126}$ Callieri, Pierfrancisco. 2007. "Barikot, an Indo-Greek Urban Center in Gandhāra.” In Srinivasan 2007: 133-164.

${ }^{127}$ Conversations with Georgios Halkias and Damien Janos, modern yavanas in Bochum, Germany, dialogues with Suchandra Ghosh and Abhishek Singh Amar, and the participation of colleagues in a project on Dynamics in the History of Religion between Asia and Europe for the International Consortium for Research in the Humanities (IKGF) have helped to clarify issues related to the synthesis of 
Thus, intercultural exchanges in the northwestern borderlands in the late first millennium BCE established foundations for patterns of cross-cultural mobility and transmission which culminated in the following periods of the Sakas and Kuṣānas.

\section{Saka Migrants and Mediators between Central Asia and South Asia}

As Indo-Greek power waned, various groups of Sakas established control of important nodes on networks of long-distance routes used for migrations, trade, and cultural transmission between Central Asia, the Iranian borderlands, and the northwestern Indian subcontinent. ${ }^{128}$ Their domination of overland routes corresponds to a critical period of heightened patronage and growth of Buddhist institutions in the first century BCE and first century CE. The profound impact of the Sakas in South Asia is gaining greater recognition, although many previous scholars regarded the Sakas (sometimes called Indo-Scythians) as mere imitators of their Indo-Greek predecessors. For example, W.W. Tarn opined that the "Sacas simply stepped into the shoes of the Greeks" (1984 [1951]: 323). Subsequent Kuṣāna dominion over a more extensive empire extending from Bactria to northeastern India has overshadowed Saka precedents. Finally, the conflation of Sakas (Śakas) with other immigrant goups (including the Indo-Greek yavanas and Iranian pahlavas) has obscured their position. Brahmanical xenologies integrate these powerful but impure mleccha rulers into the varna hierarchy as degraded Kșatriyas. ${ }^{129}$ Nevertheless, the establishment of continous Indian historical eras which are still in use, the Azes

Iranian, Hellenistic, Central Asian, and local motifs and narratives with Indian Buddhist conventions.

${ }^{128}$ For a more detailed treatment of Śaka and Kuṣanna migration routes, see Neelis, Jason. 2007. "Passages to India: Śaka and Kușāna Migrations in Historical Contexts." In Srinivasan 2007: 55-94. This section is a synopsis of this longer article, but focuses on the relevance of these migrations for patterns of Buddhist transmission.

${ }_{129}$ Pimary sources include Mānavadharmaśāstra 10.44 (Olivelle 2004: 183), Mahābhärata 3.186.26-33 (Buitenen, J.A.B. van, trans. 1973. The Mahābhārata. Chicago: University of Chicago Press, vol. 3, 586), and Patañjali’s Mahābhāssya 2.4.10 (discussed by Bronkhorst 2007: 357, n. 2). Traditional "xenologies" involving Śakas, Yavanas, and other mlecchas are examined by Halbfass, Wilhelm. 1988. India and Europe: An Essay in Understanding. Albany: SUNY Press, 172-196 (esp. 176, 181) and Parasher-Sen, Aloka. 1991. Mlecchas in Early India: A Study in Attitudes towards Outsiders up to AD 600. Delhi: Munshiram Manoharlal, 222-261 (esp. 228-232 for Śakas). 
(Vikrama) era of 58 BCE and the Śaka era of 78 CE, were originally tied to the reigns of Saka rulers, whose chronologies are reviewed below. In addition to linguistic borrowings of Iranian loanwords into Sanskrit and Prakrit languages, the initial use of Sanskrit in official inscriptions and the adoption of poetic conventions (kāvya) in epigraphic eulogies (praśastis) are connected with Saka centers in Mathura and Gujarat during the first two centuries CE. ${ }^{130}$ The active role of Sakas as patrons of Buddhist literature, art and archeology is apparent in early Buddhist manuscripts from Gandhāra, pre-Kușāṇa sculptures from Mathura, and Kharoșthī and Brāhmī inscriptions from northwestern and western regions of South Asia, but they also supported other religious groups as well. ${ }^{131}$ Sakas and other Iranian and Central Asian immigrants were not merely passive converts to Buddhism, but played active roles as mediators for the trans-cultural flow of Buddhism beyond India.

\section{Saka migrations to South Asia}

Saka immigrants, who began to arrive in South Asia around the beginning of the first century BCE, belonged to separate branches of nomadic and sedentary groups that inhabited areas of Central Asia extending from the Pontic steppes north of the Black Sea to western Mongolia. Peoples known as Sakas in Iranian and Kharoșțī inscriptions, Sakas in Sanskrit, and Scythians in western classical sources are broadly associated with material cultures and artistic styles classified as the "Scythian triad" (consisting of bronze and iron weapons, horse-

${ }_{130}$ Damsteegt 1978: 204-216; Sheldon Pollock comments: “The radical reinvention of Sanskrit culture seems to have occurred-at least, it is here that we can actually watch it occurring-precisely where one might expect it, in a social world where the presuppositions and conventions of the vaidika culture were weakest: among newly immigrant peoples from the far northwest of the subcontinent (and ultimately from Iran and Central Asia), most importantly the Sakas (the so-called Indo-Scythians), especially a branch of the Sakas known as the Western Kṣatrapas, and the Kuṣanasas" (2006: 67). Buddhist (hybrid) Sanskrit inscriptions and literature are discussed in Chapter 1 pp. $44-54$.

${ }_{131}$ Fussman, Gérard. 1980. "Nouvelles inscriptions śaka: ère d'Eucratide, ère d'Azès, ère Vikrama, ère de Kaniska." Bulletin de l'Ecole française d'Extrême-Orient (BEFEO) 67, 1-43; Fussman, Gérard. 1984. "Nouvelles inscriptions śaka II.” BEFEO 73, 31-46; Fussman, Gérard. 1985. "Nouvelles inscriptions śaka (III-IV).” BEFEO 74, 35-42, 47-51. Quintanilla 2007: 192-218; Salomon 1999a: 180-181. 
riding gear, and the so-called animal style). ${ }^{132}$ However, these features were shared by a wide range of Eurasian nomads and are not as clearly apparent in South Asia as in Central Asian burial mounds (kurgans). Before the period of migration to South Asia, three distinct groups of Sakas appear in Achaemenid monumental art and Old Persian inscriptions issued during the reign of Darius I (522-486 BCE):

1) Sakas "who are across the sea" (paradraya) in areas north of the Black Sea are mentioned only in the Naqš-i Rustam inscription, but Herodotus (4.1-162) provides many details about this group of Scythians in his account of the Darius I's campaign against them (ca. 513 BCE). ${ }^{133}$

2) Sakas "wearing the pointed cap" (tigraxauda) correspond with the Sakas or Scythians with "pointed helmets" (Greek: orthokorybantioi) listed by Herodotus (3.92) in the tenth satrapy of Media. In addition to the Naqš-i Rustam inscription, an inscription of Darius at Susa and an inscription of Xerxes from Persepolis refer to this group of Sakas. ${ }^{134}$

3) "Hauma-drinking" (haumavarga) Sakas appear together with the previous group in Old Persian inscriptions and are referred to as Amyrgian Scythians by Herodotus (7.64). ${ }^{135}$ They originally inhabited regions around the Syr Darya (Jaxartes River) in the Ferghana and Alai valleys of western Central Asia, but also settled in the Helmand valley and southeastern Iran (Seistan). ${ }^{136}$ Since this region around the Hamun Lake "is a land where the steppe and the sown are intermingled and nomads are on all sides of the lake which is large in winter while almost vanishing in the late summer" (Frye

${ }_{132}$ The Scythian triad and Central Asian burial practices are discussed by Di Cosmo 2002: 32-42, Jettmar, Karl. 1967. Art of the Steppes. New York: Crown Publishers, 195-7, and Pavlinskaya, Larisa. 1989. "The Scythians and Sakians, Eighth to Third Centuries BC.” In Nomads of Eurasia, ed. Vladimir Basilov. Los Angeles; Seattle: University of Washington, 19-31. Vogelsang 1992: 14 refers to a somewhat different 'triad' of a short sword, trilobal arrowhead, and Animal Style.

133 Briant 2002: 141-143; Kent 1953: 138.

134 Briant 2002: 173; Kent 1953: 141, 151, 186.

135 Kent 1953: 211-212.

136 P'iankov, L.V. 1994 (1996). "The Ethnic History of the Sakas.” Bulletin of the Asia Institute 8, 37-38 summarizes arguments for localizing the Amyrgians in Ferghana. Lamotte 1988 [1958]: 448 localizes this group of Sakas in Drangiāna in southeastern Iran. 
1963: 72), different groups of Sakas may have temporarily settled there in periodic seasonal migrations. ${ }^{137}$

In other Old Persian inscriptions of Darius at Behistun, Persepolis, and the Susa foundation charter, the Sakas are listed immediately after the satrapy of Gandhāra. ${ }^{138}$ W.J. Vogelsang (1992: 304-315) argues that the Sakas who infiltrated eastern Iran from areas to the north during the first half of the first millennium BCE played major roles in the establishement and maintenance of Achaemenid power. According to Vogelsang, Saka migrations to the Iranian plateau and onwards to the Near East or to the Indian subcontinent can be viewed as a recurring pattern in which nomadic migrants from Central Asia initially disrupted settled life, but eventually “.... were adopted within local structures, and either disappeared from view as a distinct ethnic unity, or turned into the new ruling class of the sedentary people, often mingling with the old group of the autochthonous population" (1992: 305). This characterization aids in understanding patterns of migration of exogenous Sakas to northwestern India towards the end of the first millennium BCE, although it is not necessarily the case that all of these groups came to South Asia from eastern Iran.

Chinese historical annals (Shi ji and Han shu) refer to Saka and Kuṣana migrations from the Western Region (Xiyu) of China in Central Asia during the second century BCE. ${ }^{139}$ According to the Han shu (96A.10b, 96B.1b, 61.4b), westward Yuezhi migrations forced the Sai

${ }^{137}$ Frye, Richard. 1963. Heritage of Persia. Cleveland: World Pub. Co.

138 Briant 2002: 173; Vogelsang 1992: 97.

139 Relevant sources compiled in the first century BCE and first century CE are translated by Hill, John E. 2009. Through the Jade Gate to Rome: A study of the silk routes during the Later Han Dynasty 1st to 2nd centuries CE: an annotated translation of the chronicle on the 'Western Regions' in the Hou Hanshu. Charleston, South Carolina: BookSurge Publishing; Hulsewé, A.F.P. and Michael Loewe. 1979. China in Central Asia: The Early Stage: 125 BC-AD 23: An Annotated Translation of Chapters 61 and 96 of the History of the Former Han Dynasty. Leiden: Brill; Thierry, François. 2005. "Yuezhi et Kouchans: Pièges et dangers des sources chinoises." In Bopearachchi and Boussac 2005: 421-539; Zürcher, Erik. 1968. "The Yüeh-chih and Kanișka in the Chinese Sources." In Papers on the Date of Kanişa, ed. A.L. Basham Leiden: Brill, 346-390. Useful guides to the secondary literature are available in Benjamin, Craig. 2000. "The Yuezhi and their Neighbours: Evidence for the Yuezhi in Chinese Sources c. 220-c. 25 BCE." In Realms of the Silk Roads, Ancient and Modern eds. David Christian and Craig Benjamin. Turnhout, Belgium: Brepols, 105-159 and Benjamin, Craig. 2007. The Yuezhi: Origins, Migration and the Conquest of Northern Bactria. Turnhout: Brepols, 52-58. 
to migrate south from areas around the Ili Basin (in modern Kyrghizstan). While the Chinese character transliterated as Sai or Se (pronounced ${ }^{*} \mathrm{~s} ə \mathrm{k} / \mathrm{s}$ g/ $/ \mathrm{seg}$ ) corresponds closely enough to Iranian Saka, Gāndhārī Saga, and Sanskrit Saka, distinctions between the Sakas and other groups are not always clear (as is also the case with Iranian and western classical sources describing Central Asian nomadic movements).${ }^{140}$ Geographical details about Saka migrations beyond the Western Region (Xiyu) are somewhat vague, but the Chinese sources nevertheless indicate that at least one branch of Sakas began to move into the northwestern Indian subcontinent without passing through the Iranian plateau. A passage in the Han shu (96B.1b) specifies that the Sai crossed the "hanging passage" (xuan $d u$ ), located between Shatial and Swat in the gorges of the upper Indus River in modern Pakistan. ${ }^{141}$ Han shu (96A.10b) also indicates that the Sakas eventually conquered Jibin, a territory commonly associated with Kashmir or Kapiśa (Begram in Afghanistan), but here perhaps referring to Gandhāra. ${ }^{142}$

During the final two centuries BCE, three separate groups of Sakas migrated to South Asia via overland routes from southeastern Iran, Bactria, and the Tarim Basin. ${ }^{143}$ Despite topographical difficulties of the proposed routes from eastern Central Asia across the Pamir and Karakorum mountains to Swat and Gandhāra, artifacts from the Pamir region and bronze objects with Scythian stylistic affinities from mountain valleys in northern Pakistan and the late survival of

${ }^{140}$ Hulsewé (1979: 104, fn. 210) transliterates Sai while Thierry (2005: 451, fn. 39) uses $\mathrm{Se}$. Gérard Fussman cautions that Chinese sources do not clearly distinguish the Sai from the Yuezhi, which in his view are "... shifting confederations of tribes without any linguistic, ethnic (i.e. racial) and probably cultural, unity" (Fussman, Gérard. 1996. "Southern Bactria and Northern India before Islam: A Review of Archaeological Reports." Journal of the American Oriental Society 116, 252).

${ }^{141}$ For localizations of the "Hanging Passage" see Stein, Marc Aurel. 1942. "From Swat to the Gorges of the Indus." Geographical Journal 100.2, 49-56 and Jettmar, Karl. 1987a. “The 'Suspended Crossing'-Where and Why?” In Pollet 1987: 95-101. Benjamin 2007: 107-109 refers to earlier theories of Chavannes and more recent investigators such as Tsuchiya who prefer to associate $x u a n d u$ with the Khunjerab or Mingteke passes that connect Tashkurgan in Xinjiang with the Hunza and Gilgit valleys in northern Pakistan, but localizations identified by Jettmar and Stein are more accurate.

${ }_{142}$ Hulsewé 1979: 105-6. Geographical references to Jibin are discussed in Routes of Buddhist Missionaries from Gandhāra, Swat, and Kashmir in Chapter 4 pp. 250-252.

${ }^{143}$ Fussman 1994a: 32; Neelis 2007: 61-63; Senior, Robert. 2001. Indo-Scythian Coins and History. Lancaster, Pennsylvania: Classical Numismatic Group, vol. 1, 12-13. 
'animal style' features in petroglyphs provide evidence of Saka migrations through northern Pakistan. ${ }^{144}$ Another closely related branch of Sakas may have migrated to the northwestern frontiers of South after crossing the Hindu Kush following conflicts with the Yuezhi and Bactrian Greeks in Bactria during a period of instability in the second century BCE. ${ }^{145}$ Strabo (11.8.2) and Justin (41) attribute the decline of the Bactrian Greek kingdoms to various groups of nomads, including Sacarauloi/Saraucae, with whom the Sakas have been identified. ${ }^{146}$ Although Strabo and other classical authors were unclear about distinctions between various groups of nomads, Konow's remark that "Scythian pressure on the Greek empire in Bactria... seems to coincide with the Indian conquests" (1929: xxii) suggests a scenario in which migratory movements of Sakas and other Central Asians forced Bactrian Greek rulers such as Demetrius and Agathokles to extend their dominions to areas south of the Hindu Kush beginning in the early second century BCE. Since Indo-Greek kings appear to have remained in control of Kapiśa during the second century BCE, a Saka military conquest does not appear to have been likely, but a series of nomadic movements may have been partially responsible for the displacement of Greek rulers first from Bactria and again from Gandhāra, Taxila and the Punjab in the middle of the first century BCE.${ }^{147} \mathrm{~A}$ third wave of Sakas migrated to the western borderlands of South Asia from Seistan in southeastern Iran and Arachosia in southern Afghanistan after a series of conflicts with the Arsacid dynasty of Parthia between 130-80

${ }^{144}$ Dani, Ahmad Hasan. 1989. History of Northern Areas of Pakistan. 2nd ed. Islamabad: National Institute of Historical and Cultural Research, 119; Fussman, Gérard. 1978. "Inscriptions de Gilgit." Bulletin de l'École française d'Extrême-Orient 65, 3-4; Jettmar, Karl. 1991. "The Art of the Northern Nomads in the Upper Indus Valley." South Asian Studies 7, 5; Litvinskyj, Boris. 1993. "Pamir und Gilgit-Kulturhistorische Verbindungen." In Antiquities of Northern Pakistan, ed. Karl Jettmar, et al. Mainz: P. von Zabern, vol. 2, 147; Narain 1957: 135-138; Neelis 2007: 64-69; and Senior 2001: 9. This evidence invalidates Tarn's objection that "no horde with its flocks and herds could ever have crossed the Hanging Pass" (1984 [1951]: 277-8).

145 Tarn 1984 [1951]: 274-299 (chapter VII: The Nomad Conquest of Bactria).

146 Strabo (11.8.2) [based on Apollodorus] refers to the Asioi, Pasianoi, Tocharoi, and Sacarauloi and Justin (41) [based on Pompeius Trogus] refers to the Saraucae and Asiani. The implications of these passages are discussed by Konow 1929: xxi-xxii; Lamotte 1988 [1958]: 450, Narain 1957: 131-134, Senior 2001: 10, and Tarn 1984 [1951]: 284-295.

${ }_{147}$ Tarn's statement that "The beginning of the end for all Greek kingdoms in India was the Saca conquests" (1984 [1951]: 320) assumes that political and cultural shifts necessarily result from military conquests. 
BCE. ${ }^{148}$ From areas of the lower Indus valley known as Sakadvipa or Saakadvīpa ("Śaka continent") in Sanskrit Purānas, this group of Sakas expanded to the Saurāstrtra peninsula of Gujarat and into the western hinterlands of the Indian subcontinent, where the Kșaharāta and Kārdamaka lines of Western Kṣatrapas continued to rule until the end of the fourth century CE.

\section{Saka Rulers in the Northwest}

Numismatic sequences and dated inscriptions are the primary sources for reconstructing chronological frameworks for the dynastic history of Saka rulers in the northwestern and western Indian subcontinent in the first century BCE and eary centuries CE. Greek and Kharosthì coin legends indicate that Maues (or Moa in Kharoșthī) was the first Śaka ruler to declare himself "king of kings" (Greek: BA $\Sigma \mathrm{I} \Lambda \mathrm{E} \Omega \Sigma \mathrm{BA} \Sigma \mathrm{I} \Lambda \mathrm{E} \Omega \mathrm{N} /$ Kharoșthī: rajatiraja) in areas of Gandhāra, Swat, and Taxila in the early first century BCE. ${ }^{149}$ Since his coins are more commonly found in areas of northwestern Pakistan rather than in regions around Kabul or in southeastern Afghanistan, he and his predescessors probably followed routes from the north across the Hindu Kush, Pamir, or possibly the Karakorum mountains rather than migrating from southeastern Iran, Afghanistan, and the lower Indus, as sometimes suggested. ${ }^{150}$

${ }^{148}$ Justin (42.1-2) provides an account of relationships with the Sakas during the reigns of Phraates II (who died in 138 BCE during a campaign against the Sakas) and Mithridates II (123-88 BCE), who reached an accommodation with the Sakas (Konow 1929: xxxvii-xxxix; Lamotte 1988: 451-2, Narain 1957: 140-141, Senior 2001: 11-12, Tarn 1984 [1951]: 320).

149 Maues' coinage is treated by Bopearachchi, Osmund. 1999. "Recent Coin Hoard Evidence on Pre-Kushana Chronology." In Alram and Klimburg-Salter 1999: 124126; Jenkins, G.K. 1955. "Indo-Scythic mints." Journal of the Numismatic Society of India 17, 1-26; Konow 1929: xxix-xxxi; Rapson, E.J. 1922. "The Scythian and Parthian Invaders." In Cambridge History of India, vol. 1, ed. E.J. Rapson. Cambridge: Cambidge University Press, 513; and Senior 2001: 1.25-38. Senior's estimate (2001: 26) of Maues' reign from c. 95/85-60 BCE seems plausible.

${ }_{150}$ Mitchener, Michael. 1976. Indo-Greek and Indo-Scythian Coinage. London: Hawkins Publications, vol. 5: Establishment of the Scythians in Afghanistan and Pakistan, $457 \mathrm{ff}$. [Maps 40-42] proposes that Maues expanded his domain from bases in the Kurram valley northwards to Taxila and Gandhāra, while Tarn (1984 [1950]: 321-323) argues that Maues conquered Taxila by sailing upriver on the Indus from southern Pakistan. In contrast, the hypothesis of Bivar, A.D.H. 1984. "Maues at Taxila: Problems of his Arrival-Route and Political Allegiance." Journal of Central Asia 7.1, 14 that Maues or his predecessors migrated from areas in the north (Hazara and Kashmir) to Gandhara and Taxila in the south is also supported by Narain 1957: 145 ff., and Senior 2001: 29-34. 
In addition to issues of coins that reflect his major position as a powerful regional ruler in the Northwest, a Kharoșthi inscription recording the establishment of Buddhist relics in Taxila dated in year 78 "of Mahārāja Moga the Great" (maharayasa mahamtasa mogasa) indicates that Saka kṣatrapas ("Satraps") acknowedged his importance by using a continuous era named after him, although this inscription is the single attestation of such a reckoning system. ${ }^{151}$ While Maues himself is not directly connected with material evidence of Buddhist patronage, he appears to have initiated a decentralized administrative network of Saka mahākșatrapas, kșatrapas and loosely affiliated subordinates who were avid Buddhist donors. ${ }^{152}$

The most prominent successor of Maues was Azes (Aya in Kharoșțī), who also declared himself "King of Kings" on widespread and voluminous issues of coins following the decline of Indo-Greek rulers, from whom he adopted depictions of Hellenistic deities. ${ }^{153}$ Since Azes initially issued coins jointly with Spalirises, an Indo-Parthian official, he appears to have expanded his dominion to Taxila and other areas of northwestern Pakistan from a base in the region of Arachosia in southeastern Afghanistan rather than directly inheriting the regions previously ruled by Maues. ${ }^{154}$ Azes' likely successors (Azilises and

151 The copper plate Kharoșthī inscription of Patika is edited by Konow 1929: 23-29, no. 13, pl. 5.1 (= CKI 46: http://www.ebmp.org/a_inscription.php?catid=CKI0046), but an identification of the era of year 78 remains disputed. Falk, Harry. 2002. "Frühe Zeitrechnung in Indien." In Vom Herrscher zur Dynastie: zum Wesen kontinuierlicher Zeitrechnung in Antike und Gegenwart, ed. Harry Falk. Bremen: Hempen, 87-88 and Robert Senior 2001: 25 argue that Maues initiated his own era, but other scholars (Tarn 1984 [1951]: 494-502, Fussman 1980: 35 ff., Salomon 1998: 181, 2005: 372) have suggested identifications with other historical eras beginning in dates corresponding to 155 BCE (“Old Śaka” era), 172 BCE ( ${ }^{\star}$ Eucratides era), and 185 BCE (Yavana era). However, as observed by Glass, Andrew. 2007b. "The Chronology of Kharoșthī Inscriptions: A reassessment in light of recent discoveries.” Gandhäran Studies 1, 61-76, these solutions result in dates for Patika and his father, ksatrapa Liaka Kusulaka, that are too early for them to also appear in Kharoșthî inscriptions on the Mathura lion capital.

${ }^{152}$ Salomon, Richard. 1974. "The Kṣatrapas and Mahākșatrapas of India." Wiener Zeitschrift für die Kunde Südasiens 18, 5-25 concludes that these titles attested in Indian coins and inscriptions denote regional subordinates and semi-independent or independent rulers depending on the political context.

${ }_{153}$ Mitchener 1976: vol. 6 (Dynasty of Azes), 481-504; Rosenfield, John M. 1967. The Dynastic Arts of the Kushans. California studies in the History of Art, 6. Berkeley: University of California Press, 127, pl. XIV, coins 269-272; Senior 2001.

${ }^{154}$ Bopearachchi and Pieper 1998: 212, 260, pl. 51, coin 246; Bopearachchi and Aman ur Rahman 1995: 168-169, coins 702-703; Rosenfield 1967: 127; Senior 2001, $1.42-43$. 
Azes II) continued to produce numerous coins, including very common types with a figure on horseback holding a spear or whip. ${ }^{155}$ Azes is also credited (perhaps in hindsight) with initiating a dynastic era beginning in $58 \mathrm{BCE}$ which later became identified with the so-called Vikrama era still used in South Asia. ${ }^{156}$ Since this important era (which no longer bears his name) was adopted by later regional rulers who acknowledged the authority of the dynastic lineage of Azes in their inscriptions and coins, his impact on this period of South Asian history deserves greater emphasis. Robert Senior links Azes with "unification of the Punjab and a great increase of wealth, evidenced by his huge output of coinage" as well as "a revolution in religious ideas brought about by the cultural mix resultant from his sitting at the hub of the Silk route" (2001: 65). Such an assessment of Azes' legacy may be exaggerated by a narrow emphasis on numismatic sources, since Azes, like Maues, is not directly connected to patronage of religious institutions and is not mentioned in literary sources. Nevertheless, the consolidation of Saka power after Azes began to rule in 58 BCE by a confederation of regional rulers who established control of major routes connecting Gandhāra to Mathura had significant implications for political, economic, and religious history.

\section{Buddhist Patronage by the Apracas and Odis}

Regional Saka subordinates, allies, and officials supported Buddhist institutions by donating relics, building stūpas, and giving donations to monastic communities in their domains. Members of the Apraca

155 Although most other numismatic specialists maintain that the "spear versus whip" criterion for distinguishing coins of Azes I from those of Azes II "holds reasonably well for separating earlier and later Azes' coins" (Mitchener 1976: 6.481), Senior 2001: 63, 71, 83 argues that Azilises' coins follow those of Maues and precede issues of Azes and dismisses the distinction between Azes I and II by regarding later coins of Azes as posthumous issues. While the relative chronological sequence remains disputed (and it is beyond my scope to resolve numismatic debates), it is interesting to note that horseriders with whips also appear in petroglyphs from various sites (Hodar, Gichi Nala, Chilas, Thalpan, and Hunza-Haldeikish) in northern Pakistan, but it is not very clear that Azes' coinage was the source of this imagery.

156 Salomon 1998: 182 briefly explains the use of the Azes/Vikrama era in Indian inscriptions. Falk 2002: 85-87 observes that this era first attested 63 years after Azes began to reign in the Indravarman casket corresponding to 5/6 CE may have been a "creation in hindsight" (Schöpfung im Nachhinein). The date in this inscription (CKI 242: http://www.ebmp.org/a_inscription.php?catid=CKI0242) is discussed by Salomon, Richard. 1982. "The 'Avaca' inscription and the origin of the Vikrama era." Journal of the American Oriental Society 102, 59-68. 
family in the northwestern borderlands of Pakistan and Afghanistan made numerous Buddhist donations recorded in Kharoșthī inscriptions dated in the era of Azes. ${ }^{157}$ Although most of these inscriptions lack specific provenance, the domain of the Aparacas was probably centered in Bajaur and extended to Swat, Gandhāra, Taxila, and parts of eastern Afghanistan in the last half of the first century BCE and the early decades of the first century CE. Since the discovery of an inscribed reliquary casket from Shinkot in Bajaur donated by the Apraca king Vijayamitra (who evidently founded the dynasty), other inscriptions record donations of relics by at least four generations of kings, queens, and court officials. ${ }^{158}$ Apraca kings known from Kharoșthī inscriptions, coins, and seals included Indravasu, Viṣnuvarman (perhaps identical to Viśpavarman), and Indravarman, but the dynastic genealogy remains uncertain. ${ }^{159}$ Another important member of the Apraca lineage was the "general" (stratega) Aśpavarman, who appears as a character in a Buddhist avadāna preserved in first-century Kharoșthī manuscript fragments and whose name is inscribed on a silver saucer found at Sirkap in Taxila. ${ }^{160}$ Since Aśpavarman's coins overlap with late or

${ }^{157}$ For Kharoșthī inscriptions of the Apracas and Odis with references to additional publications, see Salomon 2005a: 385 and Salomon, Richard. 2007. "Dynastic and Institutional Connections in the Pre- and Early Kușāna Periods." In Srinivasan 2007: 267-285. Senior 2001: 1.89-94, 2.136-143 treats Apraca coins. Rahman, Abdur. 1999. "The Role of the Udis and Aprācas in the Spread of Buddhism: A lost chapter of the History of Gandhāra." Lahore Museum Bulletin 12, 3-18 is a very brief overview. Srivastava, Prashant. 2007. The Apracharajas: A history based on coins and inscriptions. Delhi: Agam Kala Prakashan synthesizes most (but not all) of these epigraphic and numismatic sources. Callieri, Pierfrancesco. 2002. "Il periodo dei Saka e dei Parti: le dinastie di Apraca e di Oḍi ed il loro support al Budhismo." In Callieri, Pierfrancesco and Anna Filigenzi, eds. Il maestro di Saidu Sharif: alle origine dell' arte del Gandhara. Roma: IsIAO, 57-61 re-examines the evidence or Buddhist patronage by the Sakas, Parthians, and the Apracas and Odi kings, their regional allies in Bajaur and Swat.

${ }_{158}$ Majumdar, N.G. 1937a. "The Bajaur Casket of the Reign of Menander." Epigraphia Indica 24, 1-8; Konow, Sten. 1947. "Note on the Bajaur Inscription of Menandros.” Epigraphia Indica 27, 52-58; Fussman 1993a: 95-111; CKI 176: http:// www.ebmp.org/a_inscription.php?catid=CKI0176 (see note 113).

159 Apraca genealogies proposed by Falk, Harry. 1998. "Notes on Some Apraca Dedicatory Texts." Berliner Indologische Studien 11/12, 107; Salomon, Richard. 1996b. "An Inscribed Silver Buddhist Reliquary of the Time of King Kharaosta and Prince Indravarman." Journal of the American Oriental Society 116, 450; Senior 2001: 1.90, and Srivastava 2007: 139 differ considerably.

${ }^{160}$ Lenz, Timothy. 2010. Gandhäran Avadānas. GBT 6. Seattle; London: University of Washington Press, 85-93 (Avadāna 8); Salomon 1999a: 145-150; Marshall 1951, 1.188, 2.613 (= CKI 190: http://www.ebmp.org/a_inscription.php?catid=CKI0190). 
posthumous issues of Azes (II) and the Indo-Parthian ruler Gondophares (see below), he probably flourished from ca. 20-50 CE. ${ }^{161}$

Kharoșthi inscriptions indicate significant relationships between the Apracas, Oḍi kings, contemporary Saka kșatrapas, the early Kușānas, and other local dynasties during a politically turbulent period from the end of the first century BCE to the middle of the first century CE. A silver drinking vessel with an animal-style ibex figure formerly belonging to the "Yagu king" (yaguraño) Kharayosta (or Kharaosta) that was rededicated as a Buddhist reliquary by Indravarman (Aśpavarman's father) may indicate that this object was given to the Apracas as a gift in exchange for some form of tribute or assistance. ${ }^{162}$ The Apracas were also connected by marital alliance with the Odi kings in the Swat valley, since a royal relative and officer named Suhasoma in a Budddhist reliquary inscription of Senavarman (Fig. 2.2: Reliquary Stūpa of Senavarman, the King of Oḍi) was married to Vasavadattā, according to a Kharoșthī inscription recording her donation of a waterpot. ${ }^{163}$ Vasavadattā, the donor of the waterpot, may be identified with the sister of the Apraca prince Indravarma, since she is mentioned in a Kharoșţi reliquary casket inscription. ${ }^{164}$ Since Senavarman's inscription mentioning Suhasoma also refers to Sadașkaṇa, a son of the first Kuṣanna ruler Kujula Kadphises, the role of the Apracas and Odi rulers as powerful regional Buddhist patrons can be synchronized with the early Kușanas during a period of dynamic religious activity and political fluctuations at the beginning of the first century CE. ${ }^{165}$

\footnotetext{
161 Senior 2001: 92-94.
}

162 This interpretation of CKI 21 (http://www.ebmp.org/a_inscription.php?catid= CKI0241) is suggested by Salomon 1996b: 442-443.

163 Salomon 1999a: 152-155, 198-199 (British Library pot A, inscription $2=$ CKI 369: http://www.ebmp.org/a_inscription.php?catid=CKI0369); Salomon 2007: 276277. Links proposed by Salomon between Suhasoma in the Senavarma inscription (CKI 249) and Vasavadattā, the wife of Suhasoma (CKI 369) and the sister of Apraca prince Indravarman in a reliquary casket inscription (CKI 242 "Avaca Casket 1"), have been disputed by Harry Falk in his review of Salomon 1999a in Journal of Asian Studies 59 (2000), 210-211.

${ }_{164}$ CKI 242 (Avaca Casket 1): http://www.ebmp.org/a_inscription.php?catid= CKI0242 was first published by Bailey, Harold. 1978. "Two Kharoṣthī casket inscriptions from Avaca." Journal of the Royal Asiatic Society, 3-13.

${ }^{165}$ Lines 8g-9b of the Senavarma Inscription(CKI 249: http://depts.washington. edu/ebmp/inscriptions.php) link Suhasoma and with Sadaṣkana: maharaja-rayatiraraya Kuyula-Kataphsa-putro Sadașano devaputro sadha anakaena Suhasomena așmakareṇa sayuga-savalavahaṇa sadha guśurakehi ca puyita "Sadașkaṇa, son of the 


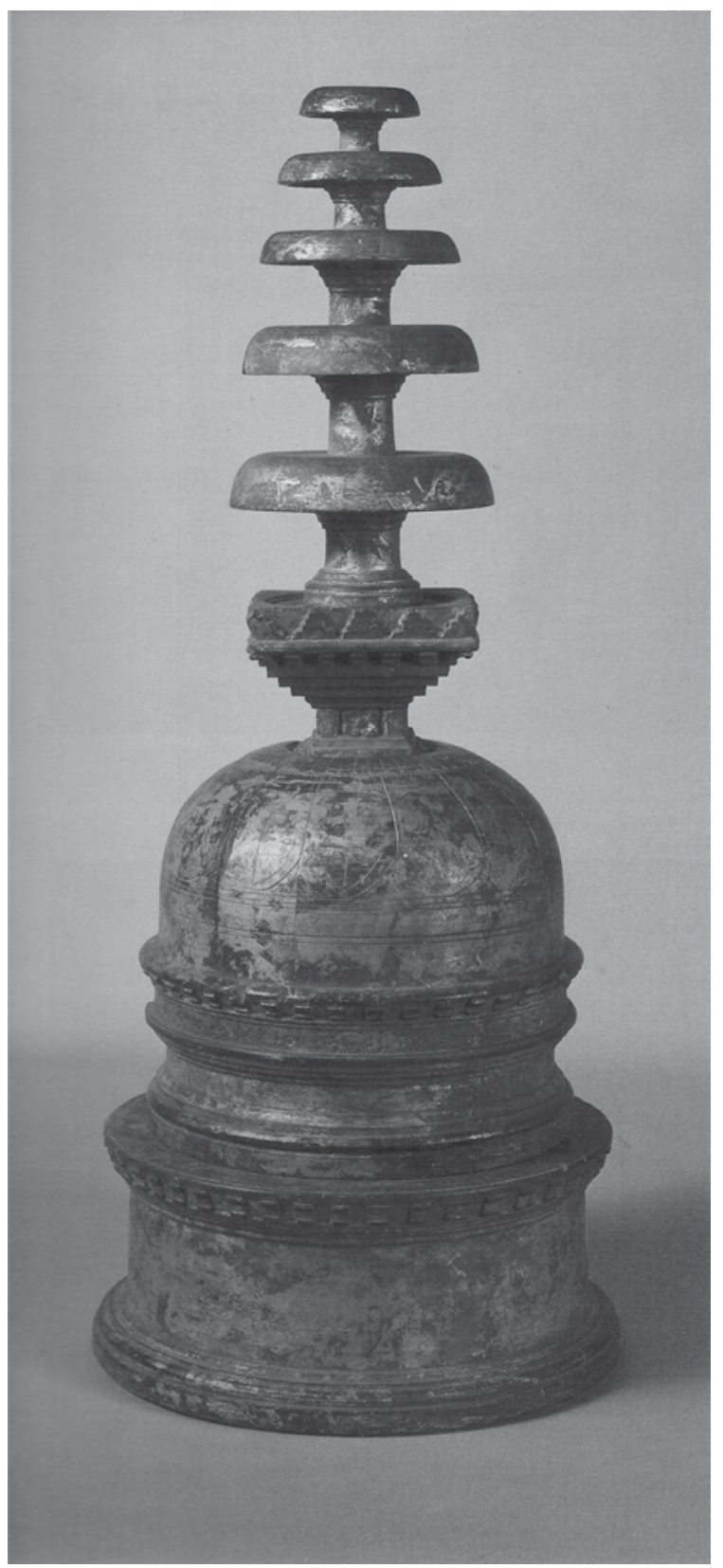

Fig. 2.2: Reliquary Stūpa of Senavarman, King of Oḍi (Source: Czuma and Morris 1985: 165, no. 82) 


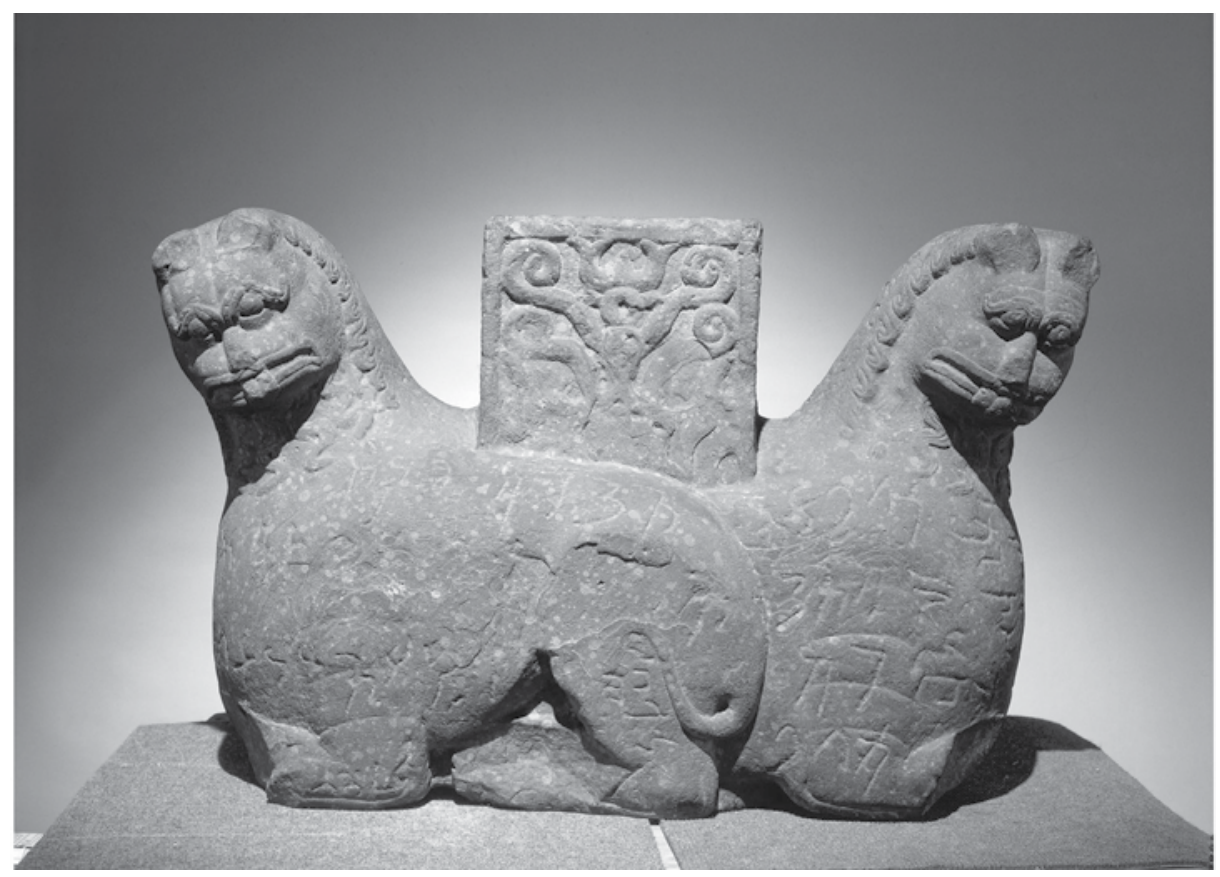

Fig. 2.3: Mathura Lion Capital (๑Trustees of the British Museum)

\section{Mathura Kṣatrapas and Mahākșatrapas}

Kșatrapas and Mahākșatrapas reigning in Mathura extended Saka administration and religious patronage from the northwestern borderlands to an important cultural and commercial center in the GangaYamuna doāb by the late first century BCE. Kharoșthī inscriptions

gods, son of the Great King, King over Kings, Kuyula Kataphsa (Kujula Kadphises), with [his] royal kinsman Suhasoma the aśmanakara (officer), with [his] mounts, with [his] forces and vehicles, with [his] guśuraka and sturaka nobles, is honored" (Salomon 1986: 271). The reading and interpretation of this Kharoșthi inscription (the longest discovered to date) first published by Bailey, Harold. 1980. "A Kharoștrī Inscription of Senavarma, King of Odi." Journal of the Royal Asiatic Society (1980), 21-29 has been significantly improved by the studies of Fussman, Gérard. 1982. "Documents épigraphiques kouchans (III): L'inscription Kharosțīi de Senavarma, roi d'Oḍi: Une nouvelle lecture." Bulletin de l'École Française d'Extrême-Orient 71, 1-46 and Hinüber 2003. Kharoșțī inscriptions of Senavarma's father Ajitasena (CKI 334: http://www.ebmp.org/a_inscription.php?catid=CKI0334) and his brother Varmasena (CKI 401: http://www.ebmp.org/a_inscription.php?catid=CKI0401) are published by Fussman, Gérard. 1986a. "Documents épigraphiques kouchans IV: Ajitasena, père de Senavarma." Bulletin de l'École Française d'Extrême-Orient 75, 1-14 + pls. 1-6 and Salomon, Richard. 2003b. "Three Kharoșthī Reliquary Inscriptions in the Institute of Silk Road Studies.” Silk Road Art and Archaeology 9, 39-51, 63-64. 
on a lion capital from Mathura provide keys to understanding links between various Saka families which ruled Taxila and Mathura. ${ }^{166}$ Since its discovery in 1869 by Bhagvanlal Indraji, epigraphists have struggled to read and interpret the inscriptions written on all surfaces of the sculpture (on its top, back, sides, front, and bottom). A relatively long passage written on top and on back of a rectangular block joining the adorsed lions commemorates the installation of Buddhist relics and donation of a stūpa and monastery to a Sarvāstivādin monastic community by the "Chief Queen" (agramaheși) of Mahäkșatrapa Rajula. Although the phrasing is ambiguous, her name may be understood as a compound, Ayasia Kamuia, or as Ayasia, the daughter (dhitra) of the Kamu[ia]. She was apparently the daughter of Kharaosta, whose name appears twice in the Mathura lion capital inscriptions with the title of "heir apparent" (yuvaraña and yuvaraya in Gāndhārī correspond to Sanskrit yuvarāja). Since Kharayosta (a variant of Kharaosta) is identified as a Mahäkșatrapa's son in a Kharoșthī inscription on the silver goblet rededicated as a Buddhist reliquary by the Apraca prince Indravarman, the Mathura lion capital inscriptions indicate kinship connections between the family of Mathura Kșatrapas and Saka lineages in the Northwest. ${ }^{167}$

Another Mathura lion capital inscription refers to Mahäkșatrapa Kusula Patika, who can be identified with the donor (mahādānapati) of Buddhist relics named Patika, the son of Liaka Kusulaka, the Kṣatrapa of Cukhsa, according to a Kharoșți inscription from

${ }^{166}$ Konow 1929: 30-49, no. 15, pls. VI-IX; Sircar 1965: 114-119, no. 24, pls XVIIXXII; Thomas, F.W. 1907-8. “The Inscriptions on the Mathura Lion-Capital." Epigraphia Indica 9, 135-147; CKI 48 (http://www.ebmp.org/a_inscription.php?catid=CKI0048). Although Konow attempts to read and interpret the haphazardly written inscriptions on the lion capital as a single epigraphic record, Sircar and Thomas split the inscriptions into separate groups. The Kharosthi i characters vary in size, but do not appear to have been written by separate hands at different times. John Rosenfield suggested that "... a ceremonial gathering at Mathurā of a large number of Śaka princes" (1967: 134) may have served as a context for writing these records, which resemble informal graffiti.

${ }_{167}$ Salomon 1996b: 424 (Inscription II: mahakṣatrapa-putrasa [ya]guraṃna khara[yosta]sa... [= CKI 241 (http://www.ebmp.org/a_inscription.php?catid=CKI0241). Since Kharayosta has the title of Yabgu-king (yaguramña) in this inscription and the title of heir-apparent (yuvaraya) in the Mathura lion capital inscriptions, it is likely that the Mathura inscriptions were written before he was elevated to the position of Yabgu-king. Yabgu, a Central Asian title corresponding to Chinese xihou, was adopted in Kușāna coin legends (Hulsewé 1979: 121-123, Rosenfield 1967: 11, Thierry 2005: 462-469, 498). Kssatrapa Kharaosta is known as the "son of Arta" and as the father of Hajatria in Greek and Kharoṣthī coin legends (Senior 2001: 98-100). 
Taxila. ${ }^{168}$ The appearance of the title and name of Mahāksatrapa Rajula's son Kșatrapa Șudasa in the lion capital inscriptions demonstrates that they were written before he inherited the title of Mahākșatrapa, as Śộasa is known in Brāhmī inscriptions from Mathura, including a Jain ayavati plaque inscription of a female donor named Amohini dated in year $72 .{ }^{169}$ If this date is reckoned according to the Azes/ Vikrama era of 57-58 BCE, a correspondence with 14-15 CE provides a terminus ante quem for the Mathura lion capital inscriptions as well as the period when Saka historical figures such as Mahäkșatrapa Patika and Yuvarāja Kharaosta were in power. Kharoșthī inscriptions written on the bottom surface of the Mathura lion capital call for the honor (puyae for Sanskrit püjāyai) of the donation to extend to "all Buddhas, the Dharma, and the Sangha" and to "all of Sakastan." The somewhat unusual use of the formula with Sakastana may reflect some conception of a Saka domain in the northwestern Indian subcontinent. By establishing themselves as powerful rulers and administrators in Mathura, Taxila, and the Punjab, the Sakas controlled a network of routes that connected the northwestern frontiers with the Indian heartland.

\section{Indo-Parthians: Mahārāja Gondophares or the Gondopharids?}

By the middle of the first century CE, Saka Kșatrapas and Mahäkșatrapas in the Northwest evidently served under the nominal authority of Indo-Parthian rulers related to Mahārāja Gondophares. However, the interpretation of numismatic and epigraphic sources for the reign of Gondophares is complicated by the "homonymy problem" (Alram 1999, 37, fn. 123) of several kings with this name or title meaning "winner of glory' during the late first century BCE and early first century CE. ${ }^{170}$

168 Konow 1929: 23-29, no. 13, pl. V.1; Sircar 1965: 124-125, no. 27; CKI 46 (http:// www.ebmp.org/a_inscription.php?catid=CKI0046). See note 151 for references to discussions of the date of this inscription in year 78 of Maues.

${ }^{169}$ Quintanilla 2007: 168-172, 275-276; Sircar 1965: 120-121, no. 25, pl. XXIII. An alternative reading of the first figure in the date as 40 rather than 70 is supported by Senior 2001: 100 on the basis of his proposed numismatic chronology for the coins of Rajuvula (Rajula), but the arguments of Sircar 1965: 125 n. 3 and Quintanilla 2007: 275-6 for a reading of 72 based on epigraphic and art historical evidence are more convincing.

${ }^{170}$ Senior argues that 'Gondophares' is in reality a title (Vindapharna-Old Persian for 'winner of glory')" (2001: 108) adopted by several successors to an original Gaondophares I, who should be dated before c. 20 BCE. B.N. Puri. 1994. "The Sakas 
Table 2.2: Saka Networks in South Asia

\begin{tabular}{|c|c|c|}
\hline Northwest and Taxila & $\begin{array}{l}\text { Mathura Lion Capital } \\
\text { inscriptions (MLCI) }\end{array}$ & Western India \\
\hline $\begin{array}{l}\text { Aya (Azes) Era of } 58 \text { BCE } \\
\text { "king of kings" } \\
\text { Azilises } \\
\text { Azes II }\end{array}$ & $\begin{array}{l}\text { Ayasia (kamuia) } \\
\text { agramahiși (primary } \\
\text { queen), daughter of } \\
\text { Kharaosta }\end{array}$ & $\begin{array}{l}\text { Kșhaharata Kṣatrapas: } \\
\text { Bhūmaka } \\
\text { Nahapāna } \\
\text { Dakhamitrā, daughter of } \\
\text { Nahapāna } \\
\text { Ușavadata, husband of } \\
\text { Dakhamitrā }\end{array}$ \\
\hline $\begin{array}{l}\text { Taxila Mahākșatrapas: } \\
\text { Liaka Kusulaka } \\
\text { kșatrapa of Cukhsa, } \\
\text { father of Patika } \\
\text { Kusulaa Patika } \\
\text { (Maues Year 78) } \\
\text { mahākșatrapa in MLCI } \\
\text { Arța mahākșatrapa, } \\
\text { father of Kharaosta } \\
\text { Kharaosta yuvarāja in } \\
\text { MLCI Hajatria, son of } \\
\text { Kharaosta in coin legends } \\
\text { Jihoniga (Zeionises) } \\
\text { mahākșatrapa, precedes } \\
\text { Kușāṇas }\end{array}$ & $\begin{array}{l}\text { Suḍasa (Azes year } 72 \text { ) } \\
\text { ksatrapa, son of Rajula } \\
\text { Abuhola mother of } \\
\text { Ayasia } \\
\text { Nada Diaka daughter } \\
\text { of Ayasia } \\
\text { Piśpasi mother of } \\
\text { Rajula } \\
\text { Ha... and Hana brother } \\
\text { and niece of Ayasia }\end{array}$ & $\begin{array}{l}\text { Kardamaka Kṣatrapas: } \\
\text { Caștana } \\
\text { (Śaka era of } 78 \mathrm{CE} \text { ) } \\
\text { Rudradāman Caștana's } \\
\text { grandson } \\
\text { (Śaka year } 72 \text { ) } \\
\text { (line continues in Ujjayinī } \\
\text { and Gujarat until ca. } 400 \mathrm{CE} \text { ) }\end{array}$ \\
\hline
\end{tabular}

Gondophares/Guduphara has been identified with King Gudnafar in the Christian apocryphal account of the visit of St. Thomas to India, but these late hagiographical sources do not necessarily provide a reliable basis for clarifying the rather complicated political history of the northwestern Indian subcontinent during the early decades of the first century. ${ }^{171}$ The legacy of Gondophares and his successors as powerful

and Indo-Parthians" (Chapter 8 in Harmatta 1994) adopts the argument that the 'Winner of Glory' title "became a sort of family name for many subsequent members of the family" (200). However, Senior's challenge to the general consensus for dating Gondophares I from c. 19-46+ CE has not received much support (Srivastava 2007: 85-92).

${ }_{171}$ According to Fussman, Gérard. 1998. L'inscription de Rabatak et l'origine de l'ère Śaka," Journal Asiatique 286, 624-625, the hagiographical sources only indicate 
rulers who expanded Indo-Parthian dominion from Arachosia (southeastern Afghanistan) to Gandhāra, Taxila, Jammu, and the western Punjab is primarily reflected in the production and distribution of coins produced in different mints. ${ }^{172}$ The single epigraphic attestation for the reign of Gondophares is a Kharoșthi inscription reportedly from Shahbazgarhi or the Takht-i Bahi Buddhist monastery in the Mardan district of Northwestern Pakistan dated in the twenty-sixth regnal year of Mahārāja Gudavhara (maharayasa gudavharasa) and in year 103 of an unspecified era. ${ }^{173}$ If the date in year 103 is calculated according to the Azes era of 58/7 BCE, the period of Gondophares' reign apparently extended from c. 19 CE to at least 45-46 CE, but it is not certain that Guduvhara refers to Gondophares himself or to a successor ruling in his name. ${ }^{174}$ Since Gondophares and other members of his family probably seem to have ruled "... by co-operating with powerful forces on the ground and by absorbing them into [their] sphere[s] of influence" through "... a system of absorption allowing local rulers to keep their independence” (Senior 2001: 110), nominally subordinate local rulers (such as the Apraca general Aśpavarman) had significant roles. Although chronological details remain disputed and the role of the Gondopharid dynasty in political history before the advent of the Kusaananas is still not clearly understood, Indo-Parthian hegemony in the Northwest in the middle of the first century CE corresponded with "a period of great prosperity and cultural achievement" (Rosenfield 1967: 129).

that an Indo-Parthian ruler with this name was still known in Syria after c. 250 CE, but do not provide evidence that St. Thomas actually met him or that he controlled Taxila.

172 Alram 1999, 37-44; Bopearachchi, 1993, 59-60; Bopearachchi and Pieper 1998, 219-223; Bopearachchi 1999, 135-136; Mitchener 1976, 5.393-394, 8.697-719; Senior 2001, 1.108-128, 2.148-158.

${ }_{173}$ Konow 1929: 57-62, no. 20, pl. XII.1; Sircar 1965: 125-126, no. 28; CKI 53 (http://www.ebmp.org/a_inscription.php?catid=CKI0053). Sadakata, Akira. 1996. "Quelques inscriptions kharoșțī provenant du marché aux antiquités de Peshawar." Journal Asiatique 284.2, 308-311, (pls. 4-5) published a Kharosțhi inscription dated in Azes year 98 (equivalent to c. $41 \mathrm{CE}$ ) during the reign of Abdagases (Avakaśa), a nephew of Gondophares (Guphara), but its authenticity is doubted by Senior 2001: 125 and Salomon 2005a: 369, fn. 19.

${ }^{174}$ Senior 2001: 125 proposes that Mahārāja Guduvhara is to be identified to Sases, a descendant of Gondophares who issued coins with legends similar to the titles used in the coins of Gondophares I, but the Kharosțhi inscription provides no indication to confirm this hypothesis. 


\section{Kṣaharāta and Kärdamaka Kșatrapas in Western India}

The Kṣaharāta and Kārdamaka lines of Saka rulers, commonly known as the Western Kṣatrapas, contended for power with the Sātavāhana dynasty from the first century CE. ${ }^{175}$ These two groups of Sakas probably came from the lower Indus region of Sind after migrating from southeastern Iran (Seistan) in the first century BCE. ${ }^{176}$ The term Kṣaharāta appears in inscriptions from Taxila and Mathura and on coins issued by Saka rulers in Sindh and Saurāsțra (the Kathiawar peninsula of modern Gujarat). ${ }^{177}$ Although the relationship with these Kṣaharātas is not very clear, Bhūmaka and his son Nahapāna issued coins as Kṣaharāta Kṣatrapas in western India. ${ }^{178}$ Brāhmī donative inscriptions in Buddhist caves at Nasik, Junnar, and Karle in the Western Ghats by Nahapāna's daughter Dakhamitrā and her husband Ușavadāta are dated in years 41-6 of an unspecified era. ${ }^{179}$ The chronology of Nahapāna's rule hinges on whether these dates refer to his regnal era or to the Śaka era beginning in $78 \mathrm{CE}$, which would result in dates corresponding to c. 119-124 CE. ${ }^{180}$ If years 41-46 instead refer to Nahapāna's regnal years, his apparently long reign can be situated in the mid-first century $\mathrm{CE}$, which would permit an identification with Manbanos, the ruler of Barygaza (modern Broach in Gujarat) in the Periplus Maris Erythraei, a koinē Greek navigational text dated

175 Mirashi, Vasudev Vishnu. 1981. The History and Inscriptions of the Sätavāhanas and the Western Kshatrapas. 2 vols. Bombay: Maharashtra state Board for Literature and Culture; Sircar, Dineshchandra. 1969. Ancient Malwa and the Vikramāditya Tradition. Delhi: Munshiram Manoharlal; and Shrava, Satya. 1947. The Sakas in India. Lahore: Vedic Research Institute (Reprint, New Delhi: Pranava Prakashan, 1981) treat literary and epigraphic sources for the Western Kșatrapas in detail. The numismatic studies of Mitchener 1976: 811-852 (vol. 9, chapters 26-27) and Senior 2001: 129-138 present conflicting views on chronological and historical issues.

176 See p. 115, note 148 .

177 Konow 1929: 24-25; Lüders 1961: 157-158 (\$ 118); Mitchener 1976: 811, 819822.

${ }_{178}$ Mirashi 1981: 1.278-9; Mitchiner 1976: 816-824; Senior 2001: 1.135-6, 2.194-6.

179 Mirashi 1981: 2.95-114; Sircar 1965: 164-173, nos. 58-62.

180 Sircar 1965: 164, fn. 1; Mirashi 1981: 1.100-108 assign these dates to the Saka era. Fynes, R.C.C. 1995. "Religious Patronage of the Sātavāhana Dynasty." South Asian Studies 11, 43-50 supports an identification with regnal years of Nahapāna, corresponding to a period between 66-71 CE. Senior 2001: 132 reckons the years according to the Azes/Vikrama era of 58/7 BCE, resulting in c. 17-12/11 BCE, but placing Nahapāna before the Common Era creates insurmountable problems of relative chronology. 
to c. 40-70 CE. ${ }^{181}$ While secure dates for Nahapāna's period are elusive, overstrikes of his coins by the Sātavāhana ruler Gautamīputra Sātakarni, who is praised for destroying the Śakas, Yavanas, and Pahlavas and for "exterminating the race of the Kșaharātas" in an inscription of his descendant Vāsișthīputra Pulumāvi, indicate that the Kșaharāta Kșatrapas in western India were defeated by the Sātavāhanas. ${ }^{182}$ Jain commentaries referring to a conflict between Nahavāna of Bharukaccha (Broach) and the Sālavāhana (Sātavāhana) rulers of Paiṭhāna (the Sātavāhana capital at Pratișțāna) lend support to the numismatic and epigraphic evidence. ${ }^{183}$ Quasi-historical memories of ongoing conflicts between the Sakas and Sātavāhanas in western India are also reflected in the Kälakācāryakathānaka, a medieval Jain hagiographic narrative which connects the origins of the Azes/Vikrama era of 57/8 BCE and the Saka era of $78 \mathrm{CE}$ with the arrival of Sakas in Ujjayini after they crossed the Indus and conquered Saurāstra. ${ }^{184}$ The struggle between the Sātavāhanas and the Sakas for control of seaports and routes across the Western Ghats to the Indian hinterland was likely to have been motivated by the lucrative trade in a variety of commodities that circulated in maritime commerce between India and Egypt during this period. ${ }^{185}$

A separate branch of Western Kșatrapas apparently called Kārdamakas succeeded the Kṣaharāta Kṣatrapas and continued to rule in Gujarat, Ujjayinī, and parts of western India until $415 \mathrm{CE}$. The origins of this family are uncertain, but a reference to a Kardamaga king who was reborn as a pig as a result of selfishness in Kharoșți manuscript fragments suggests links with Sakas in the Northwest. ${ }^{186}$

181 Casson, Lionel. 1989. The Periplus Maris Erythraei: Text with introduction, translation and commentary. Princeton: Princeton University Press, 77, 197-198, §41.14.2. The identification of Nahapāna with Manbanos is not accepted by Fussman, Gérard. 1991. "Le Périple et l'histoire politique de l'Inde." Journal Asiatique 279, 33, who disagrees that Nahapāna could have been ruling between c. 40-70 CE.

${ }_{182}$ Nāsik cave inscription of Vāsiśțhipputra Pulumāvi: Mirashi 1981: 1.31-35, 2.41-49 (no. 18, 1l. 5-6) and Sircar 1965: 203-207 (no. 86); overstrikes of Nahapāna's coins are discussed and illustrated in Senior 2001: 1.135, 2.197; also see Fynes 1995: 44, Raychaudhuri 1923: 261, Sircar 1969: 81.

183 Shrava 1947: 62; Sircar 1969: 81.

184 Konow 1929: xxvi-xxvii; Mitchener 1976: 806-7; Sircar 1969: 106-148.

185 See Seaports and Maritime Routes across the Indian Ocean in Chapter 3 pp. 217-226.

${ }_{186}$ Neelis, Jason. 2008. "Historical and Geographical Contexts for Avadānas in Kharosthī Manuscripts.” In Gombrich and Scherrer-Schaub 2008: 160-161. Raychaudhuri, H.C. 1933. "The Kārddamaka Kings.” Indian Historical Quarterly 9.1, 37-39 
The earliest attested figure in this line of Saka Kṣatrapas was Caștana, the son of Ysāmotika (or Zāmotika), who issued inscriptions dated in years 6, 11, and 52 of the Saka era of 78 CE, an astronomical era perhaps connected with the beginning of Castana's rule. ${ }^{187}$ The dates in these inscriptions indicate that Castana had an unusually long reign of 52 years (until at least $130 \mathrm{CE}$ ). While D.C. Sircar and V.V. Mirashi maintain that Caștana was appointed Kuṣanna viceroy after Nahapāna’s death "with instructions to recover the lost areas of the satrapy from the Sātavāhanas" (Sircar 1969: 86), this reconstruction is largely based on the identity of the Śaka era with a later era initiated by Kanișka and the possibility that an image of Caștana appears in a Kușanna dynastic shrine outside of Mathura. ${ }^{188}$ The expansion of the dominion of Caștana and his descendants to Ujjayini and other areas of western India does not indicate that they served as Kușanna subordinates, but instead acted as independent regional rulers who filled a void after the downfall of the Kṣaharātas and a temporary decline of the Sātavāhanas in the middle of the second century CE. ${ }^{189}$

analyzes Indian literary references that suggest connections to a Karddama River in Persia (commentary on Arthaśástra 2.11) or to a royal lineage of Kṣatriyas traced back to Kārddameya (Rāmāyaṇa, Uttarakāṇ̣a, 100.19-20), but Shrava 1947: 68 contends that Kardamaka refers to the Kardama area near modern Siddhapur in Gujarat.

187 Mirashi 1981, 2.115-9, nos. 45-9, 153-6, no. 63 and Sircar 1965, 173-175, nos. 63-66. Mirashi, Sircar, and Raychaudhuri 1923: 266 deny that the Saka era of 78 was initiated by Castana, while Fynes claims that Castana"s accession date "is almost certainly marked by the commencement of the Saka era in AD 78" (1995: 44). Falk 2002: 94 suggests that the beginning of the Śaka era may reflect the beginning of Castana's rule of Ujjayini on an auspicious date, since the first day of Caitra (April), $78 \mathrm{CE}$ corresponds with the conjunction of the sun, moon, and Jupiter in Ares. The longevity of this era may be linked to its usefulness in casting horoscopes.

${ }_{188}$ Falk, Harry. 2001. "The yuga of Sphujiddhvaja and the era of the Kusânas." Silk Road Art and Archaeology 7, 121-136; 2002: 91-95, has called attention to the fact that the Saka and Kanișka eras are treated as separate reckoning systems in the Yavanajätaka. Rosenfield 1967: 145-146 (fig. 3) provisionally labels an image from the Māt devakula as "the Caśțana statue" but acknowledges that Lüders (1961: 145$147, \$ 100$ ) reads mastana rather than șastana, which is very difficult to reconcile with Caștana's name in Brāhmī inscriptions and coins of the Western Kṣatrapas. For further details about the dating of the Kanișka era, see Early Kușāna Genealogy and Chronology pp. 133-137.

189 Ptolemy's Geography (7.1.63) (translated by McCrindle, J.W. 1885. Ancient India as described by Ptolemy. Calcutta: Thacker, Spink, \& co, 152-155), which was written c. $140 \mathrm{CE}$, refers to the capital (Greek basileion) of Tiastanos (=Caștana) at Ozene (Sanskrit Ujjayinī, modern Ujjain). For references and further discussion, see Eggermont, P.H.L. 1966. "The Murundas and the Ancient Trade-Route from Taxila to Ujjain." Journal of the Economic and Social History of the Orient 9.3, 264-265; Rosenfield 1967: 132; Sircar 1969: 87. 
A Sanskrit inscription praising Caștana's grandson Rudradāman clearly reflects the historical and cultural impact of the Western Kșatrapas. The inscription dated in 150 CE (Śaka year 72) commemorate repairs to an embankment on Lake Sudarśana at Junagadh, where the Girnar version of Aśoka's Major Rock Edicts was inscribed approximately four centuries earlier. ${ }^{190}$ The composition of this eulogy (praśasti) of Rudradāman's exploits in ornate classical Sanskrit rather than Prakrit was a significant innovation in Indian cultural history. ${ }^{191}$ Mahākșatrapa Rudradāman is praised as a skilled and learned overlord of territories extending from the lower Indus (Sindhu-Sauvira) to coastal areas just to the north of modern Mumbai (Aparānta, with its capital at Sopāra). According to the claims in the inscription, he twice conquered the Sātavāhana ruler (Sātakarṇi), who is described as "Master of the Southern Route" (dakșināpatha-pati). Despite the agonistic relationship with the Sātavāhanas, a Sanskrit inscription recording a donation of a water cistern in a Buddhist cave at Kanheri (within the urban area of Mumbai) refers to a marriage alliance between the Kārdamakas and the Sātavāhanas. ${ }^{192}$ A Sātavāhana queen who donated the water cistern was a Kārdamaka descendant and the daughter of Mahākșatrapa Ru-, probably to be identified with Rudradāman or another Western Kṣatrapa. ${ }^{193}$ The Kārdamakas consolidated their

${ }^{190}$ Kielhorn, Franz. 1905. "Junagadh Rock Inscription of Rudradaman; the Year 72.” Epigraphia Indica 8, 36-49; Mirashi 1981: 2. 121-130 (no. 51); Sircar 1965: 175-80 (no. 67). Falk 2006: 118-120 (Fig. 6 is a very clear photograph of part of the Rudradāman Sanskrit inscription), 287-288 (Girnar dam) examines the Aśokan edicts and the site of the dam built by Rudradāman. A later inscription issued during the time of Skandagupta is discussed later in this chapter under Shifting Networks of Political Power and Institutional Patronage during the Gupta Period, p. 155.

191 Comments on the Junagadh inscription of Rudradāman by Pollock 2006: 67-73 highlight its significance as a turning point in Sanskrit literary culture, but his contention that a "desacralization of Sanskrit" (70) was intitiated by the Sakas "in the interests of a new cultural politics" (73) seems hyperbolic, since earlier trends towards Sanskritization are evident in religious donations from Mathura.

${ }^{192}$ James Burgess and Bühler, Georg. 1883. Report on the Elura cave temples and the Brahmanical and Jaina caves in western India. Archaeological Survey of Western India 5. London: Trübner [reprint, 1970]), 78, no. 11, pl. LI. Also see Gokhale, Shobhana. 1991. Kanheri Inscriptions. Pune: Deccan College Post Graduate and Research Institute, 62; Lüders 1973 [1912]: 103 (no. 994); Mirashi 1981: 2.68-69 (no. 25).

${ }^{193}$ Bühler, Georg. 1883. "On the Relationship between the Andhras and the Western Kshatrapas." Indian Antiquary 12, 272-274 noted the marital link between this family of Western Kṣatrapas and the Sātavāhanas. The Kārddamaka royal lineage (kārddamakarājavamiśa) is only referred to in this inscription. 
position as a regional power through marital ties with the Sātavāhanas as well as other dynasties in the Indian subcontinent.

The Kārdamaka lineage of Western Kșatrapas continued to rule areas of western India from their bases in Ujjayini and the Kathiawar peninsula until the end of the fourth century CE. ${ }^{194}$ In addition to the marriage between the Kārdamaka princess and the Sātavāhanas discussed in the previous paragraph, the Western Kșatrapas also established marital alliances with the Licchavis of Vaiśāli in the Buddhist heartland and the Ikṣvākus in the Krishna-Godāvarī delta in the eastern Deccan, where the queens belonging to this dynasty made Buddhist donations at Nāgārjunakoṇ̣a. ${ }^{195}$ This regional dynasty of Kārdamakas issued inscriptions, coins, and seals (including a monastic sealing of the "Mahārāja Rudrasena vihära") ${ }^{196}$ until the period of the impe-

${ }_{194}$ Mirashi 1981: 1.68-86; Raychaudhuri 1923: 266-270; Sircar, Dineshchandra. 1968. "The Saka Satraps of Western India." Chapter 13 in The Age of Imperial Unity. The History and culture of the Indian people, vol. 2, ed. Ramesh Chandra Majumdar. Mumbai: Bharatiya Vidya Bhavan, 178-190; Tripathi 1942: 217-219.

${ }_{195}$ A link between the Western Ksatrapas and Licchavis is suggested by discoveries of clay seals of Prabhudamā, a queen (mahādevī) who was the daughter of Mahākșatrapa Rudrasimha, who ruled until $197 \mathrm{CE}$, and sister of Rudrasena I, who ruled for a period of 20 years from ca. 199-220 (Mirashi 1981: 1.77; Sircar 1968: 187). A marriage alliance between the Western Kṣatrapas and the Ikșvāku dynasty is attested by a memorial pillar inscription from the time of King Rudrapurusadatta (ca. 295 to 315-325 CE) at Nāgārjunakoṇda (Sircar, Dineshchandra and K.G. Krishnan. 1960. "Two Inscriptions from Nāgārjunakoṇ̣a.” Epigraphia Indica 34, 20-22). Rudradhara-bhațtārikā, one of the wives of the Ikșvāku King Virapurusadatta, is identified as the daughter of the Mahārāja of Ujjayin̄i (Ujanikā-mahār<āja>bālikā) in a Buddhist inscription at Nāgārjunikoṇda: Vogel, J.P. 1929/1930. "Prakrit Inscriptions from a Buddhist Site at Nagarjunikonda." Epigraphia Indica 20, 4-5, 19 (Āyaka-pillar inscription B 5); Sircar 1965: 231 (No. 98.2). Sircar 1968: 189 links Rudradhara-bhațāarakā with Rudrasena II, whose coins bear Śaka era dates between years 177-199, corresponding to 255-277 CE. For Buddhist donations by Ikșvāku queens, see Sircar 1965: 236-240 (nos. 102-104) and Vogel, J.P. 1930. "Additional Prakrit Inscriptions from Nagarjunikonda." Epigraphia Indica 21, 61-71. A very early copper-plate grant by the Ikșvāku king Ehavala Cāntamūla (ca. 270-294 CE) to a Buddhist community at Pithuṇ̣a has recently been published by Falk, Harry. 1999/2000. "The Pạtagaṇ̣igūdem copperplate grant of the Ikșvāku king Ehavala Cāntamūla." Silk Road Art and Archaeology 6, 275-283 and N.S. Ramachandra Murthy. 1999. "Pātaganḍigūdem plates of Ehavala Chāntamūla." Journal of the Epigraphical Society of India 25, 114-123. Also see Sircar, Dineshchandra. 1946. "Eastern Deccan." Chapter 4 in The Vākātaka-Gupta Age (Circa 200-550 AD), eds. Anant Sadashiv Altekar and Ramesh Chandra Majumdar. Banaras: Motilal Banarsidass, 64-92 for a treatment of Ikșvāku political history and Stone, Elizabeth Rosen. 1994. The Buddhist art of Nāgärjunakonda. Delhi: Motilal Banarsidass Publishers for art history.

${ }^{196}$ Mirashi 1981: 2.140-141 (no. 58). 
rial Guptas, when they lost control of ancient Mālava and Saurāșțra. ${ }^{197}$ As regional counterparts, rivals, and successors to the Kușānas and the Sātavāhanas, the Western Kṣatrapas and Ikṣvākus controlled an important network between coastal ports for long-distance maritime trade and hinterland nodes in western and eastern India with thriving Buddhist communities in the second and third centuries CE.

\section{Saka Summary}

By establishing themselves as powerful sovereigns at critical nodes in western and northwestern India, the Sakas of Ujjayinī, Mathura, and Taxila controlled important routes belonging to overland and maritime trade networks. Although their role in social, religious, and cultural transformations in this dynamic period of South Asian history has not (until recently) received as much attention as earlier Hellenistic or later Kuṣanna impacts, various donors connected with Saka courts directly contributed to the growth of Buddhist religious institutions. The establishment of relics in stuppas and gifts to Buddhist monasteries by Mahākșatrapa Patika in Taxila, the Apraca Prince Indravarman and his wife Uttarā, King Senavarman in Oḍi, Queen Ayasia in Mathura, and the Western Kṣatrapas are widely attested in Kharoșthi and Brāhmī inscriptions. References to Mahākșatrapa Jihonika, Stratega Aśpavarman, the Kardamaga King, and other Sakas in Gāndhārī avadānas acknowledges and reflects their supporting roles in "the great flowering of Gandhāran Buddhism" (Salomon 1999a: 180). The Sakas, like the Sātavāhanas and other dynasties with whom they competed, conformed to the traditional role of Indian rulers as donors to multiple groups without necessarily adopting an exclusive religious identity. ${ }^{198}$ Perhaps their adoption of Indian patterns of rulership, appropriation of South Asian religious symbolism on issues of coins, and use of Gāndhārī, other regional Prakrit languages, and Sanskrit in inscriptions facilitated their gradual acceptance as Kṣatriya rulers. However, a distinctively Saka cultural identity is difficult to recognize in literary sources that tend to reflect the ideological values and anachronistic

${ }_{197}$ Mitchener 1976, 9.827-829; Rosenfield 1967: 133; Sircar 1969: 87-105; Tripathi 1942: 218-219.

198 Fynes 1991; Marshall 1951: 1.57-58. 
historical memories of much later periods. Nevertheless, recent discoveries of manuscripts and inscriptions support Sten Konow's characterization of the Sakas as "the great intermediators" (1929: xxvi) who imported Iranian, Hellenistic, and Central Asian elements into South Asia and exported Indian religious and cultural ideals to Central Asia with the transmission of Buddhism.

\section{Dynamics of Mobility during the Kușāna Period}

Kușāna control of a network of routes between western Central Asia and the northern Indian subcontinent accelerated patterns of cross-cultural exchange, long-distance trade, and religious transmission from the first to third centuries CE. The Kuṣannas belonged to a branch of the Yuezhi (as their ancestors are known in Chinese sources), which had migrated from eastern Central Asia to Bactria under pressure from other nomadic groups during the second century BCE. ${ }^{199}$ The early Kusaananas followed similar routes as the Indo-Greeks and Sakas into the northwestern borderlands of South Asia. ${ }^{200}$ Kujüla Kadphises, who established the Kușanna line of emperors, expanded his domain across the Hindu Kush to Swat, Gandhära, and Taxila by the middle of the first century $\mathrm{CE}$, apparently overlapping with contemporary Gondopharid rulers (discussed previously). By the time of his grandson Kanișka (whose second century CE date is discussed below), the Kuṣana realm extended beyond the northwestern urban centers of Taxila and Mathura to the traditional capitals of the 'great countries' (mahājanapadas) of Kosala, Vatsa, Magadha, and Anga in northeastern India, according to a Bactrian inscription from Rabatak in northeastern Afghanistan. ${ }^{201}$ The list of of these four cities was prob-

\footnotetext{
199 Annotated translations of primary Chinese historical sources (Han Shu 96A and Shi ji 123) by Hill 2009, Hulsewé 1979, Thierry 2005, and Zürcher 1968 are referred to in note 139. Also see Benjamin 2007 for a synthesis of Chinese literary sources, archaeological evidence, and western classical sources for the Yuezhi migration to Bactria.

${ }^{200}$ Neelis 2007: 79-91 gives an expanded treatment of Kuṣāna migrations, genealogy, and chronology in South Asia. See the previous subchapters for nomadic movements and the downfall of the Indo-Greeks.

${ }^{201}$ The Rabatak inscription claims that Kaniṣka captured the cities of Sāketa [ancient Śrāvastī] (sagedo), Kauśāmbī (Kōzambo), Pātaliputra [modern Patna] (Palabotro), and Śrī Campā (Ziri Tambo). The inscription was first published by Joe Cribb and Nicholas Sims-Williams. 1995-1996. “A New Bactrian Inscription of Kanishka the Great.” Silk
} 
ably intended to reinforce claims that Kanișka "submitted all India to his will" (Sims-Williams 2004: 56), since "he who controlled these four janapada controlled India down to the Bay of Bengal" (Fussman 1998: 602). By administering a network from the Oxus basin to the Ganges delta, the Kușannas effectively unified major nodes of the northern routes known as the Uttarāpatha. ${ }^{202}$ Kusānana administration of this artery of commercial and cultural exchanges facilitated long-distance movement of merchants and missionaries between South Asia, Central Asia, and East Asia.

\section{Early Kuṣāna Genealogy and Chronology}

Recent scholarly advances have helped to resolve (or at least clarify) longstanding disputes about early Kușāna history, genealogy and chronology. Chinese historical annals indicate that the Yuezhi predecessors of the Kusānasas originally inhabited the region between the Qilian and Tien Shan mountains before conflicts with the Xiongnu forced them to gradually migrate westwards across the Tarim Basin to the Ili River Basin at the beginning of the Han period from c. 207-162 BCE. ${ }^{203}$ By c. 128 BCE (after the downfall of Bactrian Greek kingdoms), Yuezhi migrants were settled north of the Oxus River on the border of

Road Art and Archaeology 4, 75-142. A translation by Mukherjee, B.N. 1995 (1999). "The Great Kushāna Testament." Indian Museum Bulletin 30, 1-106 is less reliable. Fussman 1998: 571-651 makes extensive comments on the chronological implications. Now see Sims-Williams, Nicholas. 2004 (2008). "The Bactrian Inscription of Rabatak: A New Reading." Bulletin of the Asia Institute 18, 53-68. The identification of the first two cities in the Bactrian list at the end of line 4 and beginning of line $5(+++$ adrago and $\bar{o} z o p o$, following the latest reading of Sims-Williams) remain uncertain.

${ }^{202}$ See Chapter 3: Trade Networks in Ancient South Asia-Northern Route (Uttarāpatha) pp. 186-204.

203 According to Thierry's analysis (2005: 448, 490-491 [texts 3-4]) of relevant passages in Han shu 96A and Shi ji 123, the original homeland of the Yuezhi should be localized in territories to the west of Dunhuang. Also see Benjamin 2007: 45-97 (who accepts the standard localization of the Yuezhi homeland in Gansu) and Liu, Xinru. 2001. "Migration and Settlement of the Yuezhi-Kushan: Interaction and Interdependence of Nomadic and Sedentary Societies," Journal of World History 12.2, 268, who refers to Lin, Meicun. 1995. The Western Region of the Han-Tang Dynasties and the Chinese Civilization [in Chinese: Han Tang xiyu yu Zhongguo wen ming. Beijing: Wen wu chu ban she], $64 \mathrm{ff}$. For comments on complex intertextual relationships between Han Shu 61 and 96 and Shi ji 123, described by Zürcher as "probably a patchwork made up of fragments of Han shu 61 and 96" (1968: 358), also see M.A.N. Loewe's introduction to Hulsewé (1979: 13-25), Fussman 1998: 631 ff., and Thierry 2005: 427428, who rejects the previous hypotheses of Zürcher and Loewe that Shi ji 123 was reconstructed from Han shu 61. 
Bactria (designated as Daxia in Chinese sources) when the Han emissary Zhang Qian arrived on a diplomatic mission seeking an alliance against the Xiongnu. ${ }^{204}$ According to some of these sources, the Yuezhi realm was divided into five separate districts (yabgus), which were eventually unified by the Yabgu of Guishang named Qiujiuque, who can be identified with Kujūla Kadphises, the putative founder of the Kuṣana dynasty. ${ }^{205}$

Over his very long career (he lived past 80 years of age) Kujūla Kadphises crossed the Hindu Kush and conquered neighboring territories of the Indo-Parthians, the Kabul valley, Pușkalāvatī, and Gandhāra. ${ }^{206}$ As he acquired power in these areas, Kujūla Kadphises assumed the titles of "Kușana Yabgu steadfast in dharma" (kușana yavugasa dhramațidasa) and "Great King, King of Kings" (maharaja rajatiraja) in Kharoșthi legends on coins. ${ }^{207}$ His coins are patterned after the posthumous issues of Hermaios, the last Indo-Greek ruler of the Kabul valley, and the bull and lion coin-types of Jihoniga, a Saka Mahāksatrapa in the Punjab between ca. 30-40 CE. ${ }^{208}$ Royal portraits of Kujūla Kadphises adopted from gold coins of the Roman emperor Augustus (31 BCE-14 CE) provide a general terminus post quem. ${ }^{209}$ It is not possible to fix an absolute chronology for Kujüla Kadphises based on Chinese literary references or numismatic sources, but a reference to his son Sadașkaṇa in the Kharoṣțhī reliquary inscription of Senavarman pro-

204 Benjamin 2007: 189-209, Thierry 2005: 453-459.

${ }^{205}$ The five districts (Chinese $x i$ hou corresponds to yabgu) are referred to in Han shu 96 A (but not in Shi ji 123) and in Hou Han shu 118.9a (History of the Later Han compiled by Fan Ye [398-446 CE] based on General Ban Yong's report on the Western Regions prior to 125 CE (Thierry 2005: 492-493, text 7; Zürcher 1968: 367). Grenet, Frantz. 2006. "Nouvelles données sur la Localisation des cinq Yabghus des Yuezhi." Journal Asiatique 294.2, 325-341 convincingly argues that the five districts were located north of the Oxus River in an arc from the Gui (Wakhsh) valley (with a headquarters at Hucao perhaps localized at Takht-i Sangin) to Termez.

206 Identification of places conquered by Quijiuque/Kujūla in Hou Han shu 118.9a remain uncertain, but Fussman's explanation (1998: 637-638) that the general order in which these territories are listed (Gaofu/Kabul_Puda/Puṣkalāvatī_Jibin/Gandhāra) reflects the sequence of Kusānana conquests seems plausible.

${ }_{207}$ Bopearachchi and Rahman 1995, 37-44; for other examples, see Errington and Cribb 1992, 66, no. 34, 81, no. 75; Mitchiner 1976, 8.681-682, Type 1044-1045; and Rosenfield 1967, 12, Type I, coins 1,2,3.

${ }^{208}$ MacDowall, David W. 1973. "The Azes Hoard from Shaikhan-Dheri: Fresh Evidence for the Context of Jihonika." In South Asian Archaeology 1971, ed. Normand Hammond. Park Ridge, NJ: Noyes Press, 225, pl. 16.2, a,b (also see Mitchiner 1976, 8.690, Type 1055; Rosenfield 1967, 15, Type 4, coin 15).

${ }^{209}$ Errington and Cribb 1992, 66-68, no. 35; Mitchiner 1976, 8.688, Type 1053; Rosenfield 1967, 13-14, Type II, coins 4,5. 
vides a synchronism with the Apracas in the early-mid first century CE. ${ }^{210}$ However, if Kujūla Kadphises was acknowledged as a powerful Kusānana sovereign by subordinate rulers of the Oḍi dynasty in the Swat valley sometime during the first half of the first century CE (as indicated in the Senavarman inscription), his reign would have overlapped with the Indo-Parthian overlord Gondophares (ruling from ca. 20-46 CE). ${ }^{211}$ This quandary has raised questions about relationships between the Gondopharids and the early Kusānanas, since epigraphic and numismatic evidence indicates that both lines exerted considerable influence during the middle decades of the first century CE, with the Kușannas eventually dominating.

The Bactrian inscription at a sanctuary (bagolaggo) in Rabatak (northern Afghanistan) with images of Iranian gods and goddesses constructed during the first year of the reign of Kanișka has clarified the genealogical succession of three generations of Kuṣana rulers following Kujūla Kadphises. ${ }^{212}$ In the passage: "for King Kujula Kadphises (his) great grandfather, and for King Vima Taktu (his) grandfather, and for King Vima Kadphises (his) father, and also for himself, King Kanishka" (Cribb and Sims-Williams 1995/6: 80), Joe Cribb identifies Vima Taktu with a Kușana ruler who issued numerous coins with the title of 'Soter Megas' ("Great Savior"). ${ }^{213}$ Extensive distribution of this ruler's coins reflects an extension of Kușāna hegemony from northern

${ }^{210}$ See Buddhist Patronage by the Apracas and Odis (pp. 117-120) for a discussion of the synchronism proposed by Salomon (1999a: 141-149; 2007: 276-277) based on the marital link between the Apraca princess Vasavadattā and the Oḍi courtier Suhasoma attested in Kharosthī inscriptions (CKI nos. 242, 249, and 369).

211 The chronology of Gondophares based on references in Christian apocryphal literature and a Kharosthī inscription reportedly from Takht-i Bahi (CKI 53) is detailed in Indo-Parthians: Mahārāja Gondophares or the Gondopharids? (pp. 123-125)

${ }^{212}$ See note 201 for complete references.

${ }^{213}$ Fussman 1998: 604 and Mukherjee 1995 [1999]: 10 question Sims-Williams' reading of the name of Vima Taktu in line 13, but the alternative of Sadașana proposed by Mukherjee is not tenable. According to Sims-Williams, Vima Takto's name is legible in the opening lines of the Bactrian version of the Dasht-i Nawur inscriptions, and "Vima Taktu is the only reading which fits the traces of the king's name in both the Rabatak and Dasht-i Nawur inscriptions" (2004 [2008]: 65). A Brāhmī inscription on the base of a statue of a seated Kușāna ruler at Măt read as 1. mahārājo rājātirājo devaputro 2. Kușānapu[t]r[o șā]hi [Vema] Ta[kșu]masya by Lüders (1961: 135, \$98) may correspond with Vima Taktu in the Rabatak inscription. MacDowall, David. 1968. "Soter Megas, the King of Kings, the Kushāna." Journal of the Numismatic Society of India 30, 28-48 proposed that a "nameless king" intervened between Kujula Kadphises and Vima Kadphises before the discovery of the Rabatak inscription. 
Afghanistan to northern India as far east as Banares during his reign in the late first century CE. Vima Kadphises, who is clearly identified as Kanișka's father in the Rabatak inscription but whose name is not really legible in other epigraphic sources, ${ }^{214}$ issued the first Kuṣāna gold coins and adopted grandiloquent titles such as "King of Kings" in Greek coin legends, and "Great King, King of Kings, Lord (King) of All the World, Great Lord (King), Savior" in Kharoșțī. ${ }^{215}$ The style of depicting Vima Kadphises in a standing pose making an offering at a small altar mostly found on his copper coins is adopted in images on coins of later Kuṣanna emperors as well as royal statues in shrines at Surkh Kotal in Afghanistan and Māt across the Yamuna River from Mathura and in petroglyphs from Shatial and Khalatse on the upper Indus River. ${ }^{216}$

An absolute date for the beginning of a continuous era initiated by Kanișka is disputed, but recent findings have raised significant doubts about an identification of the Kanișka era with the Śaka era of 78 CE. ${ }^{217}$ A formula for calculating the difference between the Śaka and "Koṣāna" eras in the Yavanajātaka (79.15), an astronomical treatise written by Sphujidhvaja in $269 \mathrm{CE}$, clearly distinguishes between "the number of years that have passed of the Koșānas" (koșannagatābdasaṃkhyā) and the "the time of the Sakas (i.e., the year in the Śaka era)" (kālah śakānām $)^{218}$ The formula apparently indicates that 149 years sepa-

${ }^{214}$ Konow (1929, 79-81, no. XXIX, pl. XV.2) tentatively reads Uvima Kavthisa in a Kharoșthī inscription at Khalatse (CKI 62: http://www.ebmp.org/a_inscription. php?catid=C̈KI0062), but Sircar 1965: 134, no. 35 and Fussman 1998: 625-626 express doubts about an identification with Vima Kadphises.

${ }^{215}$ Errington and Cribb 1992: 85, no. 88; Rosenfield 1967: 22-26, coins 17-29.

${ }_{216}$ Rosenfield 1967: 26, 144ff., figs. 2-3, 119-120; Bandini-König and Fussman 1997: 9-10, pl. 1, nos. 17:40, 34:161, and 14:3; a similar petroglyph at Khalatse on the Upper Indus River is illustrated by Tucci, Giuseppe. 1958. "Preliminary Report on an Archaeological Survey in Swat." East and West 9, 294, fig. 8 and Orofino, Giacomella. 1990. "A Note on Some Tibetan Petroglyphs of the Ladakh Area." East and West 40, 196, fig. 33.

${ }_{217}$ The issue of dating the Kaniska era has been the subject of significant scholarly debate: Basham 1968; Rosenfield 1967: 253-258 [Appendix 1: "The Era of Kanișka”; Zwalf 1996: 1.357-358 [Appendix 1: "A note on ancient eras"]; Falk 2001 and Falk 2002: 95-97. Fussman 1998: 641 and Senior 2001: 1.130 still favor an initial date for the Kanișka era in 78 CE, maintaining the hypothesis that the Western Kșatrapas were subordinate to the Kușannas and adopted the reckoning system from their overlords.

${ }^{218}$ The interpretation of verse 79.15 in the last chapter of the text by Pingree, David. 1978. The Yavanajātaka of Sphujidhvaja. 2 vols. Cambridge/London: Harvard University Press, 2.187 is contested by Falk 2001: 121-136; 2002: 91-97. Falk reads and translates verse 79.15 as gatena sādhyardhaśatena yuktyā vyekena koșānagatābdasaṃkhyāl kālaḥ śakānām pariśodhya tasmād atītam anyad yugavarșayātāḥ // "The elapsed years 
rate the two eras, but Harry Falk (2001: 130) calculates $127 \mathrm{CE}$ as the beginning of the Koṣanna era (which is assumed to be equivalent to the Kanișka era) by subtracting 100 from 149 years and by adding 49 to 78 CE. Falk's proposal that one hundred years must be omitted from the formula seems likely, since there are very strong arguments for the omission of numerals for hundreds in inscribed sculptures and other inscriptions with dates in the Kanișka era. ${ }^{219}$ Although Sphujidhvaja and other astrologers were not aware that $127 \mathrm{CE}$ (rather than 227 $\mathrm{CE})$ was the initial date of the historical Koṣanna/Kaniṣka era, Falk's proposed resolution to longstanding debates over a separate Kanișka era coheres quite well with current understanding of early Kuṣāna dynastic history. However, the solution remains hypothetical until an inscription dated in both the Saka and Kanișka eras confirms Falk's interpretation of the formula in the Yavanajätaka.

\section{Paradigms of Patronage under Kanișka and Huvișka}

Buddhist literary traditions liken the Kuṣāna emperor Kaniṣka to a second Aśoka, but epigraphic and numismatic evidence indicates that he probably supported multiple religious communities. Evidence for Kanișka's patronage of Buddhist institutions is primarily based on accounts of Chinese Buddhist visitors as well as Sarvāstivādin and

of the Kusânas in combination with 149 (change into) the time of the Sakas. Subtracting from this (Śaka time [plus 56]) the elapsed (yuga, i.e. 165 years) (produces) the elapsed years of the second yuga" (2001: 127). Depending on Utpala's commentary on Bṛhajjätaka 7.9, Pingree translates: "(If one takes) the number of years of the Koșānas which have passed and adds 149, then, subtracting from this number the year in the Saka era, (one obtains a year in which) another yuga ended" (Falk 2001: 122). Both Pingree and Falk regard the Śaka and Koṣāna (Kuṣāna) eras as separate reckoning systems, but Falk proposes that the purpose of the formula is to synchronize the two reckoning systems in order to calculate the number of years that had elapsed since an astronomical yuga of 165 years began when the sun and moon enter Ares in conjunction at sunrise on meșasamkrānti (in 22 and $187 \mathrm{CE}$ ).

${ }^{219}$ Lohuizen De Leeuw, Johanna E. Van 1949. The "Scythian" Period: An approach to the History, Art, Epigraphy and Palaeography of North India from the 1st Century BC to the 3rd Century AD. Leiden: Brill [reprint, Delhi: Munshiram Manoharlal, 1995], 235-262 and Lohuizen De Leeuw, Johanna E. Van 1986. "The second century of the Kaniska era." South Asian Studies 2, 1-9 proposed that the numerals for hundreds were omitted from many Kanișka era dates. Falk, Harry. 2004. "The Kanișka era in Gupta records." Silk Road Art and Archaeology 10, 167-176 proposes that Kanișka era dates with omitted hundreds are also found in some Gupta inscriptions. Patterns of either very low or high numbers suggest that hundreds are omitted from Kanișka era dates in Kharoșțī graffiti from northern Pakistan. 
Mahāyāna texts preserved in Chinese, Tibetan, Central Asian, and Iranian languages rather than contemporary Indian Buddhist texts and inscriptions. Faxian and Xuanzang as well as later Chinese pilgrims and Al-Bīrūnī credit Kanișka with the construction of the monumental Shāh-jī-kì Ḍherī stūpa in Purușapura (modern Peshawar). ${ }^{220}$ A copper casket found at this site and inscribed with a Kharoșthī inscription was once believed to have been a Buddhist reliquary donated by Kaniṣka, but is now recognized as a "perfume box" given by two administrative superintendents of the "fire-room" in "[Mahärā]ja Kanișka's monastery" ([mahara]jasa kanișkasa vihare) in the city of Kanișkapura. ${ }^{221}$ While this epigraphic evidence links Kanișka with a major monastery in Peshawar, Buddhist imagery on Kanișka's coins is relatively limited, since Iranian, Hellenistic, and Indian deities are more frequently depicted. ${ }^{222}$ As Ellen Raven remarks:

Buddha's image was not employed before Kaniṣka on Kușāna coins, and never again after him. The Buddha is just one of a wide range of deities, from the pantheons of Iran, the Hellenistic world, Rome, and India, selected to express the king's concern for material abundance and prosperity of his realm, military triumph, legitimacy of his rule, and divine sanction for his kingship. ${ }^{223}$

Buddhist narratives with Kanișka as a prominent figure have been composed in or translated into Chinese, Tibetan, Central Asian, and Iranian languages, but he is not mentioned in Pāli literature or in Sanskrit purānas. ${ }^{224}$ A connection between Kaniṣka and the convening of a

${ }^{220}$ Kuwayama, Shoshin. 1997. The Main Stūpa of Shāh-jī-kī-Dherì: A Chronological Outlook. Kyoto: Inst. for Research in Humanities re-examines the archaeological context, while Rosenfield 1967: 34-36 discusses the literary sources.

${ }^{221}$ Errington and Cribb 1992: 196-197; Fussman1987: 77-82; Konow 1929: 135-7; Luczanits 2008: 190; Rosenfield 1967: 260-262: CKI 145 (with further references).

${ }^{222}$ Religious iconography of Kușāna coins is discussed by Rosenfield 1967: 72-103 and Cribb, Joe. 2008. "The Pantheon of the Kusānạa Kings." In Luczanits 2008: 122125 (also see 145-153, nos. 77-100). For specifically Buddhist images on coins of Kanișka, see Errington and Cribb 1992: 199-201, nos. 197-199; Cribb, Joe. 1999/2000. "Kanishka's Buddha image coins revisited." Silk Road Art and Archaeology 6, 151-189; Göbl, Robert. 1987. “Die Buddha-Darstellungen in der Münzpragung der Kušān.” In Orientalia Iosephi Tucci Memoriae Dicata, eds. G. Gnoli and L. Lanciotti. Rome: Istituto italiano per il Medio ed Estremo Oriente, 535-538; Raven, Ellen. 2006. "Design Diversity in Kanișka's Buddha Coins.” In Behrendt and Brancaccio 2006: 286-302.

${ }^{223}$ Raven 2006: 287.

${ }^{224}$ Rājataranginī 1.168-172 (Kalhana's 11th century Sanskrit chronicle of Kashmir) refers to the founding of towns and Buddhist shrines and monasteries in Kashmir by Hușka, Juṣka, and Kaniṣka 150 years after the Buddha's Nirvāna, which may reflect local historical memories of Kuṣana patronage posterior to the time of Aśoka (Stein, 
Buddhist council in Kashmir, Gandhāra, or Jalandhar (in the Punjab) which supposedly led to the writing of Sarvāstivādin Abhidharma texts on copper plates is probably a "pious fabrication" (Rosenfield 1967: 32) modeled on Theravāda accounts of a third council in Pātaliputra sponsored by Aśoka. Chinese and Tibetan Buddhist traditions also portray Kanișka as a literary patron of Aśvaghoșa, the author of the Buddhacarita and Saundarananda, and claim that Mātṛceta wrote a "letter to Mahārāja Kaṇika" (Mahārājakaṇikalekha) to instruct him in Buddhist principles. ${ }^{225}$ Buddhist claims that Kaniska was a sympathetic lay devotee and a Buddhist monarch probably have more to do with hagiographic topoi associating him with Aśoka than with his direct and certainly not exclusive patronage of Buddhist institutions.

As concrete evidence does not confirm that Kanișka was a Buddhist convert like Aśoka, historians of this period theorize that his suport of Buddhism was due to a political need to promote his status as a cakravartin by making donations to diverse groups in the expanding Kuṣanạa domain. ${ }^{226}$ Although he acknowledges that Kușānā rulers and officials under Kanișka sponsored a variety of religious institutions (including Buddhist stūpas), Xavier Tremblay contends that the Kuṣannas were

Marc Aurel, trans. 1900. Kalhana's Rājataraniginī, a chronicle of the kings of Kásmìr. London: A. Constable, vol. 1, 30-31.

${ }^{225}$ Rosenfield 1967: 30-34 refers to other literary figures ("theologians" is somewhat misleading, since their topics extended beyond theological concerns to philosophy, doxography, biography, and monastic law) such as Vasumitra, Pārśva, Saṃgharakșa, Dharmatrāta, and indirectly Nāgārjuna, since the Suhrllekha attributed to him was probably the model for Mătrceta's Kanikalekha. As Rosenfield emphasizes, “... these associations can not be taken at face value, for in the pious, pseudo-historical records of the faith, the names of great kings were often linked with those of great writers" (1967: 30).

${ }^{226}$ Rosenfield 1967: 29-30 (“...Kanishka's patronage of the faith must have been essentially politic... Kanishka may well have been, like Constantine, attracted by a variety of religions and guided as much by the exigencies of politics as by his won spritual needs"). Verardi, Giovanni. 1983. "The Kusāna Emperors as Cakravartins. Dynastic Arts and Cults in India and Central Asia: History of a Theory, Clarifications, and Refutations." East and West 33, 225-294 argues against Rosenfield's thesis of a distinctive dynastic cult of the Kusānas, but maintains that their patronage of Buddhists, Brahmans, Jains, and other religious groups was due to their need to represent themselves as cakravartins in order to address "...the problem of their own legitimation on Indian soil" (1983: 268). Chattopadhyay, Bhaskar. 1975. Kushāna State and Indian Society: A Study in Post-Mauryan Polity \& Society. Calcutta: Punthi Pustak, 179 and Sircar, Dineschandra. 1971b. Some Problems Concerning the Kușannas. Dharwar: Kannada Research Institute, 3 agree that a "catholic religious policy" (Sircar 1971b: 3) was favored, although Chattopadhyay argues in favor of syncretism and against eclecticism. 
Mazdeans and rhetorically asks: "Must then the whole of Budhist lore around Kanișka (none of which is earlier than the fifth century) be a pious fake?" (2007: 87) ${ }^{227}$ Such a question rests on an assumption that Kaniṣka and other Kuṣāna emperors sublimated their own individual religious identities in order to govern a vast domain encompassing diverse religious cultures between the Oxus basin in ancient Bactria and the Ganga-Yamuna doāb in northern India. However, as Gérard Fussman (among others) has pointed out, acceptance of the Buddha's teachings (Dharma) did not require lay devotees to give up their own Hindu, Iranian, indigenous, or other religious beliefs and practices. ${ }^{228}$ Although he did not necessarily favor Buddhists over other Indian or Iranian religious groups, under his aegis conditions of material prosperity fostered an increase in the production of Buddhist art and literature, and it is not accidental that the Senior collection of Kharoșthi manuscripts was deposited in a stūpa inside a pot inscribed with a date in the twelfth year of his reign (ca. $140 \mathrm{CE}$ ). ${ }^{229}$

Buddhist inscriptions, manuscripts and archaeological remains clearly indicate significant growth of monastic institutions and attest the emergence of the Mahāyanna movement during the long reign of Huvișka. Since the dated inscriptions of Kanișka end in year 23 of his era (corresponding to ca. 150-151 CE if the era began in $127 \mathrm{CE}$ ) and the dated inscriptions of Huvișka begin in year 26 (ca. 153-154 CE), Huvișka's immediate succession is somewhat uncertain. The tremendous output of gold coins and inscriptions dated between years 26 and 64 (until ca. $191 \mathrm{CE}$ ) indicate that Huvișka ruled for at least 35 years during a prosperous phase of South Asian cultural and economic history. ${ }^{230}$ A Mathura Brāhmī inscription from the time of Huviṣka's

227 Tremblay, Xavier. "The Spread of Buddhism in Serindia-Buddhism among Iranians, Tocharians, and Turks before the 13th century." In Heirman and Bumbacher 2007: 75-129, esp. 82-88.

228 Fussman 1994a: 25, 42.

229 Allon 2007 in Glass 2007a: 3-4; Salomon 2003c: 74-77, figs. 1-2.

${ }^{230}$ Rosenfield observes that "The numismatic and epigraphic traces [of Huvișka's rule] are the most copious of any Kushan prince" (1967: 59) and calls the gold coins issued by Huvișka a "veritable shower of gold" (1967: 60). His suggestion (based on the predominance of Iranian deities represented on Huvișka's coins) that "the tastes and interests of the Kushan princes were somewhat at variance with that of their subjects, as might be expected in a feudal social order imposed by foreign invaders" (1967: 73) neglects an "in-built conservatism" (Errington and Cribb 1992: 51) in numismatic designs, which do not necessarily reflect personal convictions or religious identities of rulers. 
successor Vāsudeva (dated in year 77, corresponding to ca. $204 \mathrm{CE}$ ) refers to "the monastery of the mahārāja rājātirāja devaputra Hūvīṣka" (Lüders 1961: 68, \$31). This epigraphic evidence to Huviṣka’s monastery at Jamalpur mound in Mathura parallels epigraphic and literary references to Kanișka's monastery in Peshawar. As during the time of Kaniṣka, Kuṣāna subordinate officials who recorded donations to numerous religious groups in inscriptions sometimes shared their religious merit with their overlord, Huvișka. For example, the "principal lot” (agrabhaga) of merit is assigned to Mahārāja Rājātirāja Huviṣka in a reliquary vase inscription from Wardak in central Afghanistan dated in year 51 (ca. $178 \mathrm{CE}$ ). ${ }^{231}$ Nascent Indian Mahāyāna traditions are attested in a Mathura Brāhmī inscription on the pedestal of "an image of the Blessed One, the Buddha Amitābha" (Schopen 1987b: 111) dated at or near the beginning of Huvișka's reign (year 26). ${ }^{232}$ Huvișka was portrayed as a Mahāyāna follower "who has set forth on the (Great) Vehicle" (Salomon 2002b: 256) in a version of an avadāna narrative preserved in fourth century Buddhist Sanskrit manuscript fragments in the Schøyen collection. ${ }^{233}$ A literary parallel to a similar story set in Huvișka's court is preserved in the Chinese translation of the Kalpanāmanditikā or Sutrālarikāra (Dazhuanyan lun jing). ${ }^{234}$ However, Prasenajit of Kosala rather than Huvișka is the king in a shorter version in the ${ }^{\star}$ Samyuktaratnapitakasūtra or ${ }^{\star}$ Kșudrakapitaka (Za bao zang jing). ${ }^{235}$ The Mathura inscription and the narrative with

${ }^{231}$ CKI 159 (http://www.ebmp.org/a_inscription.php?catid=CKI0159); Errington and Cribb 1992: 174-175; Konow 1929: 165-170. Another recently published inscription from Wardak on another vase dated in the same year and day records a relic donation by the daughter of the donor of the first vase, but does not include Huvișka among the recipients who share the merit (Falk, Harry. 2008. "Another reliquary vase from Wardak and consecrating fire rites in Gandhāra." In Religion and Art: New issues in Indian iconography and iconology, ed. Claudine Bautze-Picron. London: British association for South Asian Studies, 63-80; CKI 509: http://www.ebmp.org/a_inscription.php?catid=CKI0509).

${ }_{232}$ Schopen, Gregory. 1987b. "The inscription on the Kusān image of Amitābha and the character of the early Mahāyāna in India." Journal of the International Association of Buddhist Studies 10, 99-133 (-Schopen 2005: 247-277 [chapter 8]). The image labeled in the inscription is no longer extant, except for the feet.

${ }^{233}$ Salomon, Richard. 2002b. "A Sanskrit Fragment Mentioning King Huvișka as a Follower of the Mahāyāna.” In Buddhist Manuscripts 2, ed. Braarvig 2002: 255-267.

${ }^{234}$ Huber, Édouard, trans. 1908. Sûtrâlamkâra [attributed to Aśvaghoṣa, translated into Chinese by Kumārajīva]. Paris: E. Leroux, 423-426, no. 73. Sanskrit fragments of this narrative in the source text, Kalpanāmanditikā Drștântapanikti of Kumāralāta, are no longer preserved.

${ }^{235}$ Translated by Willemen 1994: 94-96. 
Huviṣka as a Mahāyāna follower do not prove that he played a role in the promotion of Mahāyāna, but do seem to indicate that "the time of Huvișka was a pivotal one in the development of the Mahāyāna" (Salomon 2002b: 261).

\section{Vicissitudes of the Later Kuṣānas}

Following the period of Huviṣka, the dynastic fortunes of the Kuṣannas gradually declined during the reign of Vāsudeva and his successors in the third century CE. Brāhmī inscriptions dated in Kanișka era years from 64 or 67 (ca. 191-194 CE) to 98 (ca. 225-6 CE) demonstrate that Vāsudeva ruled for at least thirty years. His apparently Vaiṣnava proper name and his coins with images of Siva (Ooesho) standing in front of Nandin (his bull vāhana) reflect a trend towards greater Indianization. ${ }^{236}$ The territory controlled by Vāsudeva may have been reduced to regions of North India and parts of the Punjab, since he is not mentioned in inscriptions from the Northwest, and the burial of his coins around Taxila suggests a crisis. ${ }^{237}$ According to Rosenfield (1967: 104-105), at least two other Kusānạa rulers were named Vāsudeva, but it is not necessary to add more Vāsudevas to the Kuṣāna genealogy if the Kanișka era begins in $127 \mathrm{CE}$ rather than $78 \mathrm{CE}$. A later Kuṣāna ruler named Kaniṣka (II) who copied Vāsudeva's coin types appears to have directly succeeded Vāsudeva after the first century of the Kanișka era (ca. $227 \mathrm{CE}$ ).

Brāhmī inscriptions from Mathura and Sãñcī dated in years 24 and 28 during the reign of an otherwise unknown Kușanna ruler named Vāsiṣka probably belong to the second century of the Kaniṣka era (with corresponding dates in 251-2 and 255-6 CE). ${ }^{238}$ A Kharoșthī

${ }_{236}$ Rosenfield 1967: 104; Sircar, Dineschandra. 1971c. "Vāsudeva-Krsṣna and Nārāyaṇa in Early Vaiṣnavism." In Studies in the Religious Life of Ancient and Medieval India. Delhi: Motilal Banarsidass, 16-38, states that Vàsudeva's name “...indicates the Bhāgavata leanings of the later Kuṣannas who had an important gubernatorial centre at Mathurā" (22). However, the Śiva and Bull motif on his coins (which appeared earlier on the coins of Wima Kadphises) indicates that Vāsudeva's religious identity was not exclusively Vaiṣnava.

${ }^{237}$ Rosenfield 1967: 105.

${ }^{238}$ A Brāhmī inscription on an inscribed pillar ( $\left.y \bar{u} p a\right)$ from Iśapur near Mathura is dated in the 24th year "of the reign of mahārāja rājātirāja devaputra șāhi Vāsiṣka" (Lüders 1961: 125-6 [\$94]), and another Brāhmī inscription on a fragment of a seated Buddha probably from Jamalpur mound in Mathura is dated in year 28, but the reading of Vāsiṣka's name is uncertain (Lüders 1961: 63 [\$28]). A Brāhmī inscription on the 
inscription found at Ārā near Attock on the Indus River in northwest Pakistan refers to a son of Vāsiṣka (Vazeșka) named Kaniṣka (III) ruling with full imperial titles in year 41 (ca. $268 \mathrm{CE}$ ), which seems to indicate that the Kușannas were still acknowledged as powerful rulers in this region. ${ }^{239}$ While scholars have suggested that Vāsișka and a nephew named Kanișka vied with Huvișka, it seems more likely that the numerals for hundreds have been omitted from the Kanișka era dates in inscriptions of Vāsiṣka and his son named Kaniṣka (III), whose reigns fall in middle to end of the third century CE. ${ }^{240}$ Thus, they probably came into conflict with Shapur I, the Sasanian ruler of Iran from 241-271 CE, who claimed to have conquered part of the Kușāna realm possibly as far as Peshawar by ca. 260 CE. ${ }^{241}$ Kushano-Sasanian rulers continued to produce Kușanna-type coins until the fourth century period of the Sasanian ruler Shapur II (309-379 CE). The political history of the former territories of the Kusananas in the northwestern borderlands from the late third to early fourth century $\mathrm{CE}$ is almost as opaque as the end of Kusāna rule in Mathura and the Ganga-Yamuna doāb, which is likewise "lost in the general obscurity which hovers over North Indian history in the later third century" (Rosenfield 1967: 115).

base of a Bodhisattva image donated to a shrine at Sāñcī commemorating Siddhārtha's first meditation under the Jambu-tree is is also dated in the 28th year of ( ${ }^{*}$ mahārāja $)$ rājātirāja ( ${ }^{\star}$ deva)putra șāhi Vās $\left({ }^{*}\right.$ )ṣka (Lüders 1912: no. 161; Majumdar 1940: 1.385; Sircar 1965: 150, no. 48; Willis, Michael. 1999/2000. "The Sānchī Bodhisattva dated Kuṣan̄a year 28." Silk Road Art and Archaeology 6, 269-273). Rosenfield comments: "on complex stylistic grounds this statue must be attributed to a much later period" (1967: 57) and he assigns it to "Images dated in a second Kushan era" with hundreds omitted (1967: 272).

239 Konow 1929: 162-165; CKI 158: maharajasa rajatirajasa devaputrasa [ka]ï[sa] rasa Vazeșkaputrasa Kanișkasa sambatsarae ekacapar[i]- [śa]ï sam 20201.

${ }_{240}$ Rosenfield 1967: 57-60; Harmatta, János, et al. 1994. "Religions in the Kushan Empire." In Harmatta, ed. 1994 posits a "triple kingship" (323) after Kanișka I when Vāsișka, Huvișka, and Kaniṣka II all ruled in year 30 of the Kanișka era, but a Bactrian inscription at Airtam and the Kamra Kharosthi inscription (CKI 158, cited in the previous note) do not support this speculative reconstruction.

${ }^{241}$ Rosenfield 1967: 116-117; Dani, A.H. and B.A. Litvinsky. 1996. “The KushanoSasanian Kingdom." In History of Civilizations of Central Asia. Vol. III: The crossroads of civilizations: AD 250 to 750, ed. B.A. Litvinsky, et al. Paris: Unesco, 103-118, esp. 104. The claim that the Sasanians caused the downfall of the Kușannas depends on an identification of Purușapura with Puškabūr in the Pahlavi version of the Kaaba-iZardusht inscription at Naqsh-i-Rustam. 


\section{Kuṣāna Conclusions}

From about the second half of the first century CE to the middle of the third century CE, the Kușannas maintained control over important nodes on a network of overland routes connecting Bactria in western Central Asia with the heartland of northern India. A chain of cities from Termez in the Oxus valley to Begram in the Hindu Kush, Peshawar in Gandhāra, Taxila in the Potwar plateau of the Punjab, and Mathura on the Yamuna River linked the multicultural empire of the Kusaananas to the Northern Route (uttarāpatha). Although the Kuṣannas did not directly administer western Indian ports ruled by the Western Kșatrapas or the so-called silk routes in the Tarim Basin, it is likely that alliances with regional rulers allowed the Kusaannas to act as intermediaries between trans-Asian overland and maritime networks. ${ }^{242}$ Kuṣāna power was linked to long-distance trade in luxury items such as silk from China, jade from Khotan, lapis lazuli from northeastern Afghanistan, and other precious commodities which appear in lists of the "seven jewels" (saptaratna) in Buddhist texts. ${ }^{243}$ The stability of overland commercial routes controlled by the Kusaananas helped to generate material surpluses used to support religious institutions, which received ample donations recorded in Kharosțhī, Brāhmī, and Bactrian inscriptions. Kuṣanna emperors such as Kaniṣka and Huviṣka are credited with the construction of stüpas and monasteries in Peshawar and Mathura and appear in narratives as exemplary rulers comparable to Aśoka and Prasenajit, but their direct role in the growth of Buddhist monasticism was probably less significant than local officials and lay donors whose offerings of relics, images, and other meritorious gifts helped to establish and maintain residential communities of monks and nuns. Kuṣanna facilitation of commercial exchanges, dynamic mobility, and cross-cultural contact between South Asia and Central

${ }^{242}$ Kușanna military and diplomatic involvement in the local affairs of Kashgar detailed in Hou Han shu 77.4a-7a and 118.13b seems to have been temporary. For further discussion of the issue of the extent of Kusanna diplomatic, military, and commercial influence, see Brough, John. 1965. "Comments on Third-century Shan-shan and the History of Buddhism." Bulletin of the School of Oriental and African Studies 28, 582-612, esp. 589; Hitch, Douglas. 1988. "Kushan Tarim Domination." Central Asiatic Journal 32, 170-192, esp. 182-183; Neelis 2007: 90-91; Rosenfield 1967: 43; Thierry 2005: 480-482; Zürcher 1968: 352-353, 369-370.

${ }^{243}$ Liu 1988/2009 and 1998 proposes that the development of a Buddhist commercial ethos was result of Kuṣāna period prosperity. 
Table 2.3: Kuṣāṇa Rulers and Dates

\begin{tabular}{lll}
\hline \multicolumn{1}{c}{ Kuṣāṇa Rulers: } & \multicolumn{1}{c}{ Kaniṣka era dates } & \multicolumn{1}{c}{ CE } \\
\hline Kujula Kadphises & NA & early-mid 1st century \\
Vima Taktu (Soter Megas) & NA & mid-late 1st century \\
Vima Kadphises & NA & late 1st century \\
Kanișka & $1-23$ & $127-$ ca. 150 \\
Huvișka & $26-64$ & ca. 153-191 \\
Vāsudeva & $64 / 7-98$ & ca. 191/194-225 \\
Kanișka II & {$[1] 05-[1] 17$} & ca. 232-244 \\
Vāsișka & {$[1] 24-[1] 28$} & ca. 251-255 \\
Kanișka III & {$[1] 41$} & ca. 268 \\
\hline
\end{tabular}

Asia was a significant catalyst for the expansion of Buddhist networks during this crucial period in the first three centuries CE.

\section{Shifting Networks of Political Power and Institutional Patronage during the Gupta Period}

Following the Kuṣanna period, Buddhist institutions successfully adapted to economic and political transitions, despite commonplace assertions that "Buddhism in Gupta India was losing out to Brahmanism" (Liu 1988: 128). A brief interlude of perhaps less than 50 years, sometimes referred to as a "Dark Interval" (Tripathi 1942: 234-236), between the post-Kuṣana phase in the late third century and the beginning of the Gupta period in 319 CE was marked by the ascendance of various regional powers, such as the Western Kṣatrapas, Ikșvākus, and Vākātakas. ${ }^{24}$ Epigraphic records of permanent endowments (akșayanīi $\bar{l})$, gifts of landed property, and interest-earning donations that enabled monasteries to reduce thier dependence on individual donations attest to the persisting strength and accelerating growth of Buddhist institutions. ${ }^{245}$ Buddhist art and architecture at Bodh Gaya,

${ }^{244}$ The cultural impact and patronage patterns of the Western Ksatrapas and Ikșvākus are discussed earlier in this chapter (Kṣaharāta and Kārdamaka Kṣatrapas in Western India, note 195 for the Ikșvākus), and the Vākātaka patterns of institutional support are treated in the following subchapter (Vākätaka Networks of Religious Patronage).

${ }^{245}$ Schopen 1994c (“Doing Business for the Lord”): 533-534 (= 2004: 52-53) points out that aksayanivivi grants dating from as early as the 1st-2nd centuries CE before the Gupta period in Andhra, Kānheri, and Mathura were widespread instruments for 
flourishing Buddhist and Jain ateliers at Mathura, and numerous high quality Buddhist sculptures with Gupta period inscriptions from Sarnath reflect an acceleration rather than slackening of artistic production at Buddhist shrines in north India. ${ }^{246}$ Although it is beyond the scope of the overview in this chapter to address internal developments within Buddhist traditions, Gregory Schopen has persuasively demonstrated that epigraphic formulae referring to monks as Śäkyabhikșus, textual production of Mahāyāna sūtras, and doctrinal elaborations associated with prominent figures mark the institutionalization of Mahāyāna during the Gupta period. ${ }^{247}$ Historians such as Ramashankar Tripathi argue that the "catholicity of the age" (1942: 274) and the "beneficient rule of Gupta emperors who were men of catholic culture" (277) was responsible for the vitality of Buddhist literary and visual culture. While some Gupta subordinates acted as Buddhist donors, the Guptas themselves generally drew on Vaiṣnava imagery and language to portray themselves as "supreme devotees" (paramabhägavatas), perhaps in a conscious effort to legitimate themselves as supreme rulers. ${ }^{248}$ The impact of this official propaganda appears to have been limited to dynastic temples, such as those at Udayagiri, and does not seem to have adversely affected Buddhist communities, since Buddhist monuments located within walking distance at Sãñcī continued to prosper. Therefore, the pattern is one of increased Buddhist artistic and literary output, which was probably stimulated by a competitive religious atmosphere.

supporting a variety of religious institutions. Also see Maity, Sachindra Kumar. 1970 [1957]. Economic Life in Northern India in the Gupta Period (Cir. AD 300-550). Delhi: Motilal Banarsidass, 36-42.

${ }^{246}$ Williams, Joanna. 1982. The Art of Gupta India: Empire and province. Princeton: Princeton University Press, 28-33 (Mathura in early Gupta period), 148-150 (Sarnath), 150-151 (granite railing additions at Bodh Gaya during the late Gupta period).

${ }^{247}$ Schopen 1979: 15 (= 2005: 238); Schopen 2000b. "The Mahāyāna and the Middle Period in Indian Buddhism: Through a Chinese Looking-glass." Eastern Buddhist n.s. 32.2, 1-25 (= Schopen 2005: 3-24).

${ }^{248}$ Willis, Michael D. 2009. The Archaeology of Hindu Ritual: Temples and the Establishment of the Gods. Cambridge: Cambridge University Press makes an impressive case for a strong link between Hindu, specifically Vaiṣnava, religious architecture and Gupta imperial patronage based on an in depth analysis of the archaeological site of Udayagiri and an extensive treatment of Gupta inscriptions and related literary texts. 


\section{Vākāțaka Networks of Religious Patronage}

The Eastern and Western Vākātakas dominated the northern Deccan from the late third to fifth centuries and effectively controlled overland networks across India. ${ }^{249}$ Recent excavations of an Eastern Vākāțaka temple complex at Mansar near Rāmagiri in Maharashtra and ongoing research in the Buddhist caves at Ajanțā patronized by the Western Vākātakas have reaffirmed their cultural and religious significance. ${ }^{250}$ The historical and geographical origins of the early Vākātaka kings remain obscure, but a relationship with Nàga rulers who succeeded the Kuṣannas in Mathura and Vidiśā is indicated by epigraphic references to the marriage between the daughter of Bhavanāga, the Bhāraśiva king of Padmāvatī (identified with Pawāyā about 125 miles south of Mathurā in Madhya Pradesh) and Gautamiputra, the son of Pravarasena I, a "Vākāțaka emperor" (saṃrād-vākāṭaka) from ca. 275-335 CE. ${ }^{251}$ After Pravarasena's reign, the Vākāțaka genealogy split into two separate lines of the Eastern Vākātakas ruling in Nandivardhana (in ancient Vidarbha outside of modern Nagpur) and the Western Vākāțakas in Vatsagulma (modern Basim further to the southwest). ${ }^{252}$ By the end

${ }^{249}$ Contributions by Bakker, Hans. 1997. The Vākātakas: An Essay in Hindu Iconology and Art. Groningen: Egbert Forsten and Bakker, Hans, ed. 2004. The Vākātaka Heritage: Indian culture at the crossroads. Groningen: Egbert Forsten, as well as Shastri, Ajay Mitra. 1992. The Age of the Vākätakas. New Delhi: Harman Publishing House, and Shastri, Ajay Mitra. 1997. Vākāttakas: Sources and History. New Delhi: Aryan Books International have significantly clarified and expanded the scope of earlier historical studies by Altekar, A.S. 1946. "The Vākātakas." Chapter 5 in Majumdar and Altekar 1946: 86-115 and Yazdani, Ghulam, ed. 1960. The Early History of the Deccan. London: Oxford University Press, vol. 1, 149-200 (Part 3 by A.S. Altekar). Since the publication of Mirashi, V.V. 1963. Inscriptions of the Vākattakas. Corpus Inscriptionum Indicarum, 5. Ootacamund: Archaeological Survey of India, the number of known Vākātaka inscriptions has more than doubled (Bakker 1997: 2).

250 Bakker, Hans, ed. 2008. Mansar: The Discovery of Pravareśvara and Pravarapura Temple and Residence of the Vākātaka King Pravarasena II. Groningen: Library of the University of Groningen [e-book available online: http://mansar.eldoc.ub.rug .nl/]; Schlingloff 1987 Spink, Walter M. 2005. Ajanta: history and development. Leiden: Brill, 5 vols.

${ }^{251}$ Altekar 1946: 90-94; Bakker 1997: 9-10; Mirashi 1963: xix-xx, 13-14; Raychaudhuri 1923: 255-256; Sircar 1965: 442-449 (no. 62). Also see Williams 1982: 16-21 for an assessment of Nāga history and art as a possible prelude to Gupta monumental Hindu art and architecture.

${ }^{252}$ Bakker 1997: 168 (Appendix II) and Mirashi 1963: v-vi provide genealogical charts of separate Vākāțaka lineages, but Mirashi cautions that "The Vākātaka chronology is still more or less conjectural" (v). Although many scholars view the Eastern Vākattakas as the "main branch" or interpret the predominance of one line over the 
of the fourth century, the Eastern Vākātakas had become allies with the Guptas through a marriage between Rudrasena II (a grandson of Gautamīputra) and Prabhāvatī Guptā, the daughter of Candragupta II (reigning ca. 376-415) and Kuberanāgā (who belonged to one of the Nāga families). Following her husband's death in $405 \mathrm{CE}$, Prabhāvatī Guptā reigned as a powerful dowager queen and continued to exercise significant influence over her sons Dāmodarasena (reigning ca. 415422) and Pravaresena II (422-457), who shifted his royal residence to Pravarapura (modern Mansar) and constructed an impressive temple to Śiva named Pravareśvara. ${ }^{253}$

In apparent contrast to the Eastern Vākātakas, who depicted themselves as devotees of Viṣnu and Siva in their inscriptions and established a network of Hindu temples and shrines around Rāmagiri, the Western Vākātakas are directly linked with elaborate Buddhist cave complexes at Ajanțā and Ghațotkaca during the reign of Hariṣeṇa at the end of the fifth century (ca. 460-478). ${ }^{254}$ While some caves at Ajanțā were excavated as early as the first or second centuries BCE (nos. 9, 10, 12), praśasti inscriptions indicate that Harișeṇa's minister Varāhadeva was the donor of the Ghatotkaca cave and Ajanțā cave 16, while a local ruler who was subservient to Harișeṇa donated Ajaṇtā caves 17 and 19. ${ }^{255}$ Buddhist paintings and architecture in the Ajaṇtā caves not only serve as valuable art historical evidence, but also reflect the cir-

other in different periods, Kulke, Hermann. 2004. "Some Thoughts on State and State Formation under the Eastern Vākāțakas." In Bakker 2004: 1-9 comments on Vākāțaka historiography and argues that "The inscriptions of both so-called branches of the Vākātakas thus neither contain any hint at a united dynasty nor at the quest for some kind of superiority by one of the two branches" (2004:3).

${ }^{253}$ Prabhāvatī Guptā's role as a patroness of royal Vaiṣnava ideology and symbolism is emphasized by Bakker, Hans. 1992. "Memorials, Temples, Gods, and Kings: An attempt to unravel the symbolic texture of Vākātaka kingship." In Ritual, State and History in South Asia: Essays in Honour of J.C. Heesterman, ed. A.W. Van Den Hoek, et al. Leiden: Brill, 7-19. See Bakker 2004: 71-85 and 2008 (including appendix 1 with Vākāțaka and Gupta comparative chronology) for Pravarasena’s establishment of Pravarapura and the temple of Pravareśvara at Mansar.

${ }^{254}$ Spink 2005: vol. 2, 3-8, 174-196 limits the period of construction and painting of the later Ajantā caves to a "Short Chronology" of ca. 462-480, when a crisis following the death of Harisena lead to "breakdown of patronage." However, Williams 1982: 181-187, von Stietencron (in Bakker 2004: 107-108), and other scholars (including Schlingloff and Zin, see note 264 below) hold that a longer range must have been necessary. Bakker 1997: 41 points out that the Buddhist caves were not dedicated by Harișena himself, and probably continued to be excavated after the Aśmakas had gained control of the area from the Western Vākătakas.

${ }^{255}$ Mirashi 1963: 103-129 (nos. 25-27). Also see Wood, Leela Aditi. 2004. "The Ajanta Cave 17 Inscription as a Preface to the Local King's Vihāra: History, Religious 
culation of both mainstream and Mahāyāna texts (such as Āryaśūra's Jātakamālā and probably the Saddharmapundarīkā-sütra) as well as widespread symbols such as the "Wheel of existence" (bhavacakra). ${ }^{256}$ Hans Bakker suggests that control of an important north-south trade route through Ajaṇțā connecting Ujjayinī to Pratișthāna stimulated Buddhist donations by Western Vākāțaka courtiers, while Eastern Vākātaka donations of land grants to Brahman communities and temples can be attributed to a prosperous rural agrarian economy. ${ }^{257}$ Bakker's hypothesis of a correlation between the growth of a significant Buddhist complex at Ajanțā and a network of overland trade routes belonging to the Daksingapatha corresponds well to the general pattern in which Buddhist shrines and monasteries are located on or near major trade networks. ${ }^{258}$ However, a strict dichotomy between urban patronage of Buddhists and rural support for Brahmans would be misleading, since many important Buddhist shrines (like Ajanțā) are found far away from cities.

\section{Gupta 'Golden Age’ Reappraised}

A persistent historiographical dichotomy between the 'Golden Age' of imperial Gupta rulers who are portrayed as quasi-nationalist supporters of "vigorous Brahmanic revival and restoration" (Bhandarkar 1920: 51) and a decline of Buddhist institutions with the withdrawal of

Story and Homology." In Bakker 2004: 109-132 and Cohen, Richard. 2006. “Ajanta's Inscriptions." Appendix to Spink 2005: vol. 2, 273-339.

256 Relationships between textual sources and Buddhist narratives depicted in Ajaṇtā paintings have been masterfully treated by Dieter Schlingloff and Monika Zin in numerous articles collected (in English translation) in Schlingloff 1987. Schlingloff, Dieter. 2000. Erzählende Wandmalereien: Handbuch der Malereien 1. 3 vols. Wiesbaden: Harrassowitz and Zin, Monika. 2003. Devotionale und ornamentale Malerei: Ajanta, Handbuch der Malereien 2. 2 vols. Wiesbaden: Harrassowitz are authoritative guides. Also see Schopen 2005: 278-298 and Teiser 2006: 76-103 for studies of individual paintings.

${ }^{257}$ Bakkker 1997: 44-45. According to Bakker 2004: v, one main north-south itinerary from Prayāga (Allahabad) at the Ganga-Yamuna confluence to Pratișthāna (Paithan) on the upper Godavari River passed through the Western Vākātaka kingdom, while another north-south route from Kauśāmbī to the lower Krishna-Godavari delta (formerly the domain of the Ikșvākus) passed through the capital of the Eastern Vākattakas. East-west routes through the territories of the Eastern and Western Vākāțakas from Dakșiṇa Kośala (modern Chattisgarh) to western coastal ports at Sopara and Kalyan bisected the north-south arteries.

${ }^{258}$ Routes and nodes of this network are investigated in more detail in the subchapter on the Southern Route (Daksināpatha) in Chapter 3 (pp. 205-217). 
foreign support does not withstand scrutiny. ${ }^{259}$ Claims that "Brahmanical Hinduism became dominant all over India, and other religious systems were more or less neglected" (Chatterjee 2005: 199) are typically followed by retractions (“... but Buddhism retained its hold in many centres”), since Buddhist material and cultural contributions as well as internal developments during this period are difficult to overlook. ${ }^{260}$ Michael Willis traces the modern construction of a Gupta 'Golden Age' to Vincent Smith, for whom "...the reign of a great monarch in a golden age would have to have been long, happy and glorious" (2005: 142-143). ${ }^{261}$ Romila Thapar has questioned "...the notion of a uniformly Golden Age that encompasses an entire society" (2003: 280) and argues that "the Gupta period is the threshold to a marked mutation of north Indian society during the late-first millennium AD rather than a revival or renaissance" (2003: 282). ${ }^{262}$ The Guptas appropriated precedents set by earlier Indian rulers by revising and reinventing the past, so that their dynastic names, titles, inscriptions, and dating systems can seem like "a historical palimpsest" (Thapar 2003: 283).

259 Bhandarkar, Ramkrishna Gopal. 1920 [1897]. A Peep into the Early History of India: From the foundation of the Maurya Dynasty to the downfall of the imperial Gupta Dynasty (322 BC-circa 500 AD). Bombay: D.B. Taraporevala, quoted in Bhandarkar, Devadatta Ramakrishna, Bahadurchand Chhabra and Govind Awamirao Gai, eds. 1981. Inscriptions of the Early Gupta Kings, Corpus Inscriptionum Indicarum 3. New Delhi: Archaeological Survey of India, p. 122. La Vallée Poussin, Louis de. 1935. Dynasties et Histoire de l'Inde depuis Kanishka jusqu'aux invasions musulmanes. Paris: Boccard refers to juxtapositions between the "National" character of the Gupta period and the foreign character of the earlier period by R.G. Bhandarkar, A.B. Keith, and Vincent Smith (1935: 30). Gérard Fussman observes that "proclamations of admiration" for the Guptas are often based on sentiments associating Indian nationalism with Hinduism, the view that Gupta royal patronage was responsible for a peak in the quality of Indian art and Sanskrit literature, and overly literal interpretations of eulogistic praśasti inscriptions (Fussman, Gérard. 2006-2007. "Les Guptas et le nationalisme indien.” Annuaire de la Collége de France, 2006-7, p. 696). ${ }_{260}$ Chatterjee, Asim Kumar. 2005. A Comprehensive History of Buddhism. Kolkata: Punthi Pustak.

${ }^{261}$ Willis, Michael. 2005. "Late Gupta History: Inscriptions, Coins and Historical Ideology." Journal of the Royal Asiatic Society 3rd series, 15.2, 131-150.

262 Ali, Daud. 2004. Courtly Culture and Political Life in Early Medieval India. Cambridge: Cambridge University Press also highlights the significance of the "VākātakaGupta imperial formation" as the beginning of a "400-year period (c. 350-750 CE) which saw the development, crystallization, and proliferation of a common political culture throughout all major regions of the subcontinent" (2004: 20). 
Gupta origins are uncertain, but a marriage between Candragupta I and Kumāradevī, a Licchavī princess in Magadha, where Buddhist institutions maintained a very strong presence, probably allowed them to initially consolidate their power in northeastern India. ${ }^{263}$ Since this region (ancient Magadha) was also the homeland of the Mauryas, the personal name of Candragupta may deliberately recall this earlier line of rulers founded by a figure with an identical name. The Guptas emulated the Kuṣannas by giving the imperial title of Mahärājādhirāja to Candragupta and successive Gupta rulers and by striking coins based on Kușaña models. ${ }^{264}$ The Guptas continued to use the Kaniṣka era (with hundreds omitted) in inscriptions dated "in the continuous year" (kālānuvartamāna-samvatsare) along with a "victorious royal year" (vijayaräjya-samvvatsare) of the Gupta era beginning in $319 \mathrm{CE} .{ }^{265}$ Since the Gupta era was not used until the time of Candragupta II, who began ruling sometime before $388 \mathrm{CE}$, Candragupta I and his successor Samudragupta are somewhat arbitrarily assigned reigns of 20 to 25 years. ${ }^{266}$

${ }^{263}$ Bhandarkar et al. 1981 suggests that since Kumāradevī was apparently the Licchavī ruler's only child, "she naturally succeeded him to his kingdom and administered it along with her husband" (1981: 6). A link with the Licchavīs is clear from the Allahabad pillar inscription, which indicates that Samudragupta was the 'daughter's son of the Licchavi, born from mahādevī Kumāradevì' (1. 29: licchavi-dauhitrasya mahādevyām Kumāradevyām=utphannasya).

${ }^{264}$ Candragupta is titled Mahārājādhirāja in Samudragupta's Allahabad pillar inscription (Fleet 1888: 16), but in the Gupta genealogy of Prabhāvatī Guptā's Poona and Roddhapur copper-plate inscriptions (Mirashi 1963: 7-8 (no. 2), 36-37 (No. 8)) Candragupta has the same title of Mahārāja as Ghatotkaca, the "first king of the Guptas" (Guptādirāja/ Guptānam=ādirājo). See Raven, Ellen. 1994. Gupta gold coins with a Garuda-banner, Samudragupta-Skandagupta. Gonda indological studies, v. 1. Groningen: Egbert Forsten, 25-33 for a detailed discussion of typologial links between Gupta and Kuṣāna coins.

${ }_{265}$ Falk 2004: 167-176; Salomon 1998a: 186 (\$5.5.1.6: “Gupta-Valabhī era of AD 319"); and Schmiedchen, Annette and Fred Vierkus. 2002. "Die Ären der Guptas und ihren Nachfolger: Politische Kultur, Regionalgeschichte und Zeitrechnung im alten und früh-mittelalterlichen Indien." In Falk 2002: 106-137. Schmiedchen and Virkus point out that the initial use of the newly created Gupta era in Mathura during the reign of Candragupta II was an aspect of self-representation that helped to intensify their imperial image in an impotant metropolitan area formerly dominated by the Kuṣānas and Śakas (2002: 111).

266 Following Falk 2004: 169-172, the date of the Mathura pillar inscription of year 61 "in the continuous year" is calculated from 327 CE rather than $319 \mathrm{CE}$. 
The commemoration of Samudragupta's exploits in a classical Sanskrit inscription written on an Aśokan pillar at the confluence of the Ganga and Yamuna rivers marks an important juncture in South Asian political and cultural history. ${ }^{267}$ Thapar remarks that "It is curious that he should have chosen this pillar, carrying the pillar edicts of Ashoka, suggesting either that he was claiming some historical continuity or, if the earlier inscriptions could stil be read, that he was taking a contrary stand to the views of Ashoka" (2003: 283). Although the first four lines (two verses) of the inscription are damaged, the genealogy of early Gupta rulers near the end of the inscription specifies that Mahārājas (Śrī)Gupta and Ghațotkaca and Mahārājādhirāja Candragupta preceded Samudragupta. The epigraphic eulogy (praśasti) in praise of Samudragupta's military expeditions and personal qualities was composed by a court poet named Harișena. ${ }^{268}$ This ornate composition of mixed prose and verse is regarded as an impressive example of the campu style of Sanskrit poetry (kāvya) and represents a significant transition from Prakrit to Sanskrit in royal inscriptions, since "From this point on, all the inscriptions of the Guptas and their neighbors an feudatories in northern India were written in correct classical Sanskrit" (Salomon 1998a: 92). ${ }^{269}$ Daud Ali (2004: 83) argues that ubiquitous references to 'fame' (kìrti, yaśas) in this inscription of Samudragupta and thousands of other praśastis show that building a reputation was probably an important motivating factor.

Caution is necessary in interpreting the claims of conquest attributed to Samudragupta, however, since the "the conventional bombast and rhetorical exaggeration of the praśasti style" (Salomon 1998a: 229) was not intended to serve as an objective account of historically verifiable events. Thus, Harișena's claims that Samudragupta increased his glory by "capturing and then liberating" twelve southern kings of Dakșināpatha and "violently exterminating" eight kings of Āryāvarta in a 'conquest of the directions' (digvijaya) can not be accepted at face value, since his military expeditions were probably limited to

${ }^{267}$ Fleet 1888: 1-17 (no. 1); Sircar 1965: 262-268 (no. 2).

268 Ali 2004: 46 comments that Harișena was awarded the titles of 'officer for peace and war' (sandhivigrahika), 'princely counselor' (kumārāmātya), and 'great leader of the forces' (mahādandanāyaka) for assuming various service functions in the royal household, and was probably treated on a level similar to military retainers and vassals (2004: 46). Richard Salomon remarks that "...the composition of such panegyrics was perhaps more a labor of daily bread than of love" (1998a: 236).

${ }^{269}$ See also Salomon 1998: 110-113 for further discussion of epigraphic praśastis. 
regions directly to the south and east of the Narmada River valley not controlled by the Vākātakas and to territories adjacent to the GangaYamuna doāb. ${ }^{270}$ References to Kușāna successors in the Northwest as Daivaputra-Ṣāhi-Ṣāhānu-Ṣāhis and to the Western Kṣatrapas (probably) as Śaka-Murundias together with the Simhalas "and all the other island-dwellers" (sarvva-dvīpa-vāsibhir-) more likely reflects a vague awareness of distant rulers and peoples than submission to Samudragupta.

Samudragupta issued a series of gold coins with the emblem of Garuda (the mount, or vāhana, of Viṣnu) and another series of coins and seals commemorating the performance of a horse sacrifice (aśvamedha). ${ }^{271}$ Later Gupta inscriptions of Kumāragupta issued in year 96 (415/6 CE) and of Skandagupta (reigning ca. 456-467) refer to Samudragupta as "the restorer of the Aśvamedha sacrifice that had long been in abeyance" (Fleet 1888: 44, 51). ${ }^{272}$ While numismatic and epigraphic evidence reflects the religious proclivities of Samudragupta and the Gupta dynasty, R.C. Majumdar's statement that "there can be hardly any doubt that his reign marked a distinct revival of the old glory and influence of the Brahmanical religion which had suffered decline since Aśoka made Buddhism the dominant religion of India" (1954: 15) pushes this evidence too far, since his impact on religious beliefs and practices beyond the royal court was relatively limited.

After Samudragupta's reign, there was a succession dispute between Rāmagupta and Candragupta II, who eventually consolidated Gupta dominion. Jain image inscriptions from Vidiśā referring to Mahārājādhirāja Rāmagupta and gold coins issued by Kācagupta

${ }^{270}$ Fleet 1888: 12-13 (lines 19-21). For efforts to localize the rulers who are said to have been conquered, see Bhandarkar, Chhabra and Gai 1981: 12-25 and Sircar 1965: 265. Following La Vallée Poussin 1935: 45, it is necessary to read between the lines of fantastic formulae which "give an aspect of vassality to their diplomatic relations," since the foreign countries were completely independent.

271 Raven 1994 thoroughly examines Gupta gold goins with the "Garuda-Banner" issued by rulers form the Samudragupta to Skandagupta and discusses epigraphic references and images on royal seals and Gupta period art, concluding that "...the valiant king of birds, Garuda Vainateya, is the perfect representative of Gupta kingship, might and glory" (1994: 196), and symbolizes a bond between Gupta kings and Vāsudeva/ Vișnu. Lindquist, Steven. 2003. "Enigmatic Numismatics: Kings, Horses, and the Aśvamedha Coin-type." South Asian Studies 19, 105-112 argues that the images of the horse and Śrī on the Aśvamedha coins of Kumāragupta I and Samudragupta fulfill narrative and representational purposes, since the king can be identified with the horse and the queen with Śrī.

272 Bhandarkar, Chhabra and Gai 1981:35-42, Sircar 1965: 275. 
(probably identical to Rāmagupta) lend credence to Sanskrit and Arabic literary references to a struggle between Rāmagupta (Rawwāl in Arabic) and Candragupta (Barkamāris) in which Candragupta killed Rāmagupta and took his wife Dhruvadevī after Rāmagupta was defeated by the Sakas (Western Kșatrapas). ${ }^{273}$ As Michael Willis remarks, rivalry for the Gupta throne was fiercely contested:

Each king was forced to engage in a vigorous struggle for political, military and ritual supremacy. The system was sufficiently precarious and predatory that the king's attempt to create a working circle of power could come unraveled at any moment (2005: 144).

Rāmagupta's "circle of power" appears to have been restricted to the Mālava region around Vidiśā and it is uncertain that he ruled for very long (ca. $375-380$ is a very rough estimate).

Candragupta II succeeded in expanding the Gupta domain during a long reign of over thirty years (ca. 380-415). His own marriage with Kuberanāgā, a Bhāraśiva Nāga princess, and the marriage between their daughter Prabhāvatī Guptā and the Eastern Vākāṭaka ruler Rudrasena II cemented alliances with important allies in northern and central India. ${ }^{274}$ His conquest of the Western Kṣatrapas in Ujjayinī and Gujarat at the beginning of the fifth century (ca. 409/10 CE) was a signal event, since the Guptas now controlled important links between overland networks and ports in western India. ${ }^{275}$ Legends associating Vikramāditya (an epithet of Candragupta II) with the establishment of the Azes (so-called "Vikrama") era of 58 BCE anachronistically recall his campaigns against the Western Kșatrapas. ${ }^{276}$ By building monuments for worshipping Viṣnu in the form of Nārāyaṇa, Varāha

${ }^{273}$ Bhandarkar et al. 1981: 46-52 provide a detailed account of the inscriptions, coins, and versions in literary sources, including Viśākhadatta's Devīcandraguptam (lost but fragments preserved in Nätyadarpana), Bāṇa's Harșacarita, Bhoja's Śrngāaraprakāśa, Rājaśekhara's Kāvyamimāmsāa, and the Majmālut-Tawārikh. Majumdar 1962: 17-18 (with further references) and Tripathi 1942: 248-249 doubt the veracity of the Rāmagupta 'romance.' However, Bakker, Hans. 2006. "A Theatre of Broken Dreams: Vidiśa in the Days of Gupta Hegemany.” In Interrogating History: Essays for Hermann Kulke, eds. Martin Brandtner and Shishir Kumay Parda, Delhi: Manohar, 165-187, esp. 166-170, assesses the literary sources, epigraphic references in later Rāsțtrakūṭa praśasti inscriptions, and coinage of Rāmagupta and Candragupta II to demonstrate how Candragupta II consolidated political power through matrimonial alliances following a successful coup d'état.

${ }^{274}$ La Vallée Poussin 1935: 47.

${ }^{275}$ La Vallée Poussin 1935: 48, Bhandarkar et al. 1961: 53-54, Sircar 1965: 282 (no. 13: inscription on silver coins of Candragupta in Gupta year 90+ $x=409 / 10+$ ), Tripathi 1942: 250-251.

${ }^{276}$ Salomon 1982: 65-68; Salomon 1998: 182; Sircar 1969: 165-166. 
(boar) and Narasiṃha (man-lion) at Udayagiri outside of Vidiśā, Candragupta II explicitly identified himself as a "supreme devotee" (paramabhāgavata). ${ }^{277}$ However, a donation by Amrakārdava at the nearby site of Sāñci stūpa 1 during the reign of Candragupta II shows that patronage of Buddhist communities by members of the Gupta court continued. ${ }^{278}$

After a period of relative stability during the first half of the fifth century, the strength of the Gupta dynasty declined precipitously as a result of internal turmoil, external threats, and the growing autonomy of regional subordinates. Kumāragupta I, a son of Candragupta II and Dhruvadevī, ruled for at least thirty years from ca. 415-447. ${ }^{279}$ Inscriptions issued during his reign are mostly Brahmanical donations, although a few Jain and Buddhist inscriptions are attested. ${ }^{280}$ After Kumāragupta, there was another succession dispute between his brother Ghatotkacagupta and his bastard son, Skandagupta. ${ }^{281}$ At Junagadh, on the same rock inscribed with the Girnar version of Aśoka's major rock edicts and Rudradāman's praśasti inscription of $150 \mathrm{CE}$, an elaborate Sanskrit inscription records the construction of a temple to Viṣnu and repairs to the dam on Sudarśana lake between 455-458 CE by a local subordinate of Skandagupta named Cakrapālita, whose father Parṇadatta had been appointed governor of Saurāsțra. ${ }^{282}$ Another private donor of five Jain images at the village of Kakubha (modern Kahāum in Gorakhpur district in northeastern Uttar Pradesh) in 460 CE effusively praised Skandagupta:

Lord over a hundred kings, who is like Śakra (Indra), whose audience hall is fanned by the breeze from the bowing of the heads of hundreds of kings, who was born in the lineage of the Guptas, whose glory has spread afar, and who prospers above all others. ${ }^{283}$

277 Williams 1982: 40-55; Willis 2009.

${ }^{278}$ Fleet 1888: 29-34 (no. 5); Williams 1982: 37.

279 Dates for Kumāragupta I are fixed by the Bilsad pillar inscription of Gupta year 96 (415-416 CE) and the Dāmodarpur copper-plates of Gupta year 128 (447 CE) (Willis 2005: 136).

${ }^{280}$ Fleet 1888: 39-47 (nos. 8-11); Sircar 1965: 285-295; Bhandarkar et al. 1981: 77-78 refer to Buddhist and Jain donations.

${ }^{281}$ Bakker 1997: 25-29; Bakker 2006: 178-179; Willis 2005: 136. In later Gupta genealogies, Purugupta is listed as Kumāragupta's successor.

${ }^{282}$ Fleet 1888: 56-65, no. 14; Sircar 1965: 307-316. The appointment of Parnadatta and his son Cakrapālita as hereditary Gupta regional administrators apparently resulted from a practice of "appointing protectors (or 'mini-Guptas': goptrnn) in all countries" (sarvveșu deśeșu vidhāya goptṛn, line 6, verse 7).

${ }^{283}$ Translation by Salomon (1998a: 275) of the Kahāum Pillar Inscription (Fleet 1888: 65-68, no. 15; Sircar 1965: 316-317). 
In the Bhitari stone pillar inscription, Skandagupta claimed to have restored the fortunes of his faltering dynasty by conquering the Hūnas. ${ }^{284}$ Skandagupta was followed by a quick succession of Gupta rulers: Narasiṃhagupta, Kumāragupta II, and Budhagupta within a single decade (468-476/7 CE). ${ }^{285}$ Seals of Budhagupta and Viṣnugupta from Nālandā provide evidence for the establishment of this important center of monastic scholarship in the Gupta heartland. ${ }^{286}$ Vainyagupta himself acted as a Buddhist donor in the Gunaighar Copper-Plate inscription of $507 \mathrm{CE}$ from the Comilla district in modern Bangladesh, but this is the only example of direct Gupta patronage and belongs to the latest phase of Gupta dynastic history. ${ }^{287}$ The limited distribution of inscriptions and seals of Vainyagupta and Viṣnugupta seem to indicate that a short-lived Gupta resurgence at the beginning of the sixth century was restricted to Bihar and Bengal. The Guptas relied on a network of allies to establish and maintain control of critical regions, but their former regional subordinates asserted themselves and groups of outsiders, particularly the Hūnas, filled the void as Gupta power declined.

Table 2.4: Vākāṭaka-Gupta Genealogy and Chronology ${ }^{288}$

\begin{tabular}{|c|c|c|}
\hline Eastern Vākāṭakas & Western Vākāțakas & Guptas \\
\hline \multicolumn{2}{|c|}{ Vindhyaśakti (c. 250) } & Ghațotkaca (c. 300-319) \\
\hline \multirow{2}{*}{\multicolumn{2}{|c|}{$\begin{array}{c}\text { Pravarasena I (c. 275-335) } \\
\text { Gautamīputra }^{290}\end{array}$}} & Candragupta I \\
\hline & & \\
\hline $\begin{array}{l}\text { Rudrasena I } \\
\text { (c. 335-360) }\end{array}$ & Sarvasena I (c. 330-355) & $\begin{array}{l}\text { Samudragupta } \\
\text { (c. } 350-375)\end{array}$ \\
\hline
\end{tabular}

${ }^{284}$ Fleet 1988: 52-56, no. 13; Sircar 1965: 321-324. Bhitarī may have been an imperial mausoleum for the Guptas (Bhandarkar et al 1981: 83). Huns (Sanskrit Hūnas) are discussed in more detail in Kidāras and Huns in Northwestern Indian subcontinent.

${ }^{285}$ The chronology of later Gupta rulers is uncertain, but the genealogy and dates presented in Table-follow Willis 2005, wose reconstruction differs from Bhandarkar et al. 1981: 84-89 (who place Narasimphagupta last in a series of four brothers beginning with Vainyagupta).

286 Sircar 1965: 339-340.

287 Sircar 1965: 340-345.

${ }^{288}$ Based on Bakker 1997: 168-171 (Appendices II-III); Bakker 2008; Willis 2005: 135, fig. 1 .

${ }^{289}$ Marriage with Kumāradevī (Licchavī princess).

${ }^{290}$ Marriage with daughter of Bhavanāga (Bhāraśiva ruler). 
Table 2.4 (cont.)

\begin{tabular}{|c|c|c|}
\hline Eastern Vākāṭakas & Western Vākāṭakas & Guptas \\
\hline $\begin{array}{l}\text { Prrthvīsena I } \\
\text { (c. 360-395) }\end{array}$ & $\begin{array}{l}\text { Vindhyaśakti II } \\
\text { (c. } 360-400)\end{array}$ & Rāmagupta (c. 375) $)^{291}$ \\
\hline $\begin{array}{l}\text { Rudrasena } \mathrm{II}^{293} \\
\text { (c. 395-405) }\end{array}$ & $\begin{array}{l}\text { Pravarasena II } \\
\text { (c. } 400-415)\end{array}$ & $\begin{array}{l}\text { Candragupta II (c. 375/ } \\
380-415)^{292}\end{array}$ \\
\hline $\begin{array}{l}\text { Divākarasena } \\
\text { (before c. } 419 \text { ) }\end{array}$ & Unknown & $\begin{array}{l}\text { Kumāragupta I } \\
\text { (c. 415-447) }\end{array}$ \\
\hline $\begin{array}{l}\text { Dāmodarasena } \\
\text { (c. 415-422) }\end{array}$ & & Purugupta ${ }^{294}$ \\
\hline $\begin{array}{l}\text { Pravarasena II } \\
\text { (c. } 422-457)\end{array}$ & & $\begin{array}{l}\text { Ghațotkacagupta } \\
(\text { c. } 448-455)^{295}\end{array}$ \\
\hline \multirow[t]{2}{*}{$\begin{array}{l}\text { Narendrasena } \\
\text { (c. } 457-475)\end{array}$} & $\begin{array}{l}\text { Devasena } \\
\text { (c. } 450-460)\end{array}$ & Skandagupta (c. 456-467) \\
\hline & Harișeṇa (c. 460-478) & $\begin{array}{l}\text { Narasimhagupta } \\
\text { (c. } 467-474 \text { ?) }\end{array}$ \\
\hline \multirow[t]{4}{*}{$\begin{array}{l}\text { Pṛthvīsena II } \\
\text { (c. 475-495) }\end{array}$} & & $\begin{array}{l}\text { Kumāragupta II } \\
\text { (c. } 474 ?-476)\end{array}$ \\
\hline & & Budhagupta (c. 477-488) \\
\hline & & Vainyagupta (c. 508) \\
\hline & & Viṣṇugupta (c. 515?) \\
\hline
\end{tabular}

Cross-cultural Transmission between South Asia and Central Asia, ca. 500-1000 CE

Competition for economic, political, and religious power affected patterns of cross-cultural contact and exchanges between South Asia and Central Asia during a period of instability after the downfall of the Guptas in the middle of the first millennium CE. Local and regional

\footnotetext{
${ }^{291}$ Perhaps identified with Kācagupta (immediate successor of Samudragupta), first husband of Dhruvadevi in Devīcandraguptam.

${ }^{292}$ Marriage with Kuberanāgā (Bhāraśiva Nāga princess).

${ }^{293}$ Mariage with Prabhāvatī Guptā (daughter of Candragupta II), who continued to rule from c. 405-419.

${ }^{294}$ Son of Kumāragupta, did not rule.

${ }^{295}$ Perhaps married to Atibhāvatì (his niece), the daughter of Prabhāvatī Guptā and Rudrasena II (Bakker 1997: 17).
} 
polities emerged, solidified, and expanded their domains in the Indian subcontinent while acting as patrons of competing Buddhist, Saiva, Vaișnava, and other religious movements. Ronald Davidson links the "early medieval vitality" of Indian religions, literature, and art to "the valorization of regional identity" and a "discourse of divine power" whereby "the gods became kings even as the kings became gods" (2003: 74). ${ }^{296}$ The systematic use of imperial metaphors of divine apotheosis in public inscriptions and literary texts composed in the courts of rulers who aspired to fulfill the cakravartin ideal of universal overlordship provides a political-historical context for the development of a "mature synthesis of esoteric Buddhism" (Davidson 2002: 114 ) and the monastic institutionalization of Saiva Tantrism, both of which provided rival rituals of consecration (abhiseka), powerful texts and formulas (mantras), and religious ideologies to confer royal legitimacy. ${ }^{297}$ Volatile political alliances, changing military alignments, and fluctuating migration patterns did not result in insular stagnation, but often caused shifts in transregional routes for commercial exchanges and religious transmission. Contemporary sources from this period, including the accounts of Chinese travelers, inscriptions of visitors to Indian Buddhist centers, and material artifacts found far way from their original contexts, attest significant mobility via overland and maritime itineraries. The emergence of new trade networks and merchant communities (such as the Sogdians in Central Asia) and macroregional conflicts between Indian, Chinese, Central Asian, Tibetan, and Arab forces had major impacts on cultural transmission, sometimes prompting the creation of new ties and in other cases constraining access. The re-emergence of the northwestern borderlands as a contact zone between South Asia and Central Asia deserves special emphasis, since Buddhist literary and material cultures flourished at nodes for long-distance trade and political administration loosely con-

296 Davidson, Ronald M. 2002. Indian Esoteric Buddhism: A Social History of the Tantric Movement. New York: Columbia University Press.

${ }^{297}$ Sanderson, Alexis. 2009. "The Śaiva Age: The Rise and Dominance of Śaivism during the Early Medieval Period." In Genesis and Development of Tantrism. Shingo Einoo, ed. Tōkyō: Sankibō Busshorin, 41-350 provides a detailed survey of royal patronage of Buddhism (pp. 70-116), but argues that Śaivism absorbed or provided the models for Buddhist Tantrism (252). His claim that the repertoire of Saiva rituals and theory promoted economic, policial, and social processes that encouraged "intellectual and aesthetic vigour" (253, n. 590) applies equally well to a Buddhist impetus. 
trolled by a network of rulers affiliated with the Kidara and Alchon Huns or local dynasties like the Palola Șāhis of Gilgit.

\section{Kidāras and Huns in the Northwestern Indian Subcontinent}

Like their Saka and Kușāna predecessors, the Kidāra and Alchon Huns migrated to the Indo-Iranian borderlands from Central Asia as a result of Xiongnu nomadic expansion. Although relationships between Hunnic groups known as the Hūnas in Indian sources (and Chionites or Hephthalites in western sources) remain unclear due to conflicting reports about their origins and identities, they filled a significant gap by asserting control of areas between the eastern frontier of the Sasanians and the northwestern borderlands of the Guptas and their allies beginning in the fifth century CE. ${ }^{298}$ Based primarily on analysis of coins and seals, a group identified as the Kidāras emerged as autonomous rulers of large areas between Gandhāra and western Central Asia in the fifth century (ca. 430-477). ${ }^{299}$ Chinese sources based on the report of Dong Wan's mission to the Western Regions in 437 CE affiliate the Kidaras (Juduoluo) with the Yuezhi (rather than the Xiongnu), but the testimony attributed to him may have been copied from or harmonized with later historical texts. ${ }^{300}$ The Kidāras portray themselves as "restorers of the previous order" (Grenet 2002:

${ }^{298}$ La Vaissière, Étienne de. 2003 (2007). "Is There a 'Nationality of the Hephtalites'?” Bulletin of the Asia Institute 17, 119-132.

${ }^{299}$ Grenet, Frantz. 2002. "Regional Interaction in Central Asia and Northwest India in the Kidarite and Hephthalite periods." Proceedings of the British Academy 116, 203224. Grenet's dates are adopted, although the chronological range for the Kidaras is highly uncertain, since the Chionites with whom they are sometimes identified are assigned to a period beginning in the fourth century immediately after the Sasanians lost control of Bactria in the mid-370's during the rule of Shapur II (Grenet 2002: 206). La Vaissière's hypothesis that “... all the nomadic kingdoms that flourished in Bactria between the middle of the fourth century and the middle of the sixth century can trace their origin back to a single episode of massive migration in the second half of the fourth century (circa 350-370), and not to a whole set of successive migrations" (2003 [2007]: 122) alleviates problematic associations between the Chionites and Kidāras, while leaving a significant lag before the Kidāras emerged as regional political power.

${ }_{300}$ Passages referring to the Yuezhi affiliation of the Kidāras and Hephtalites in Wei $s h u$ ("History of the Wei") chapter 102,8b (p. 2278), Bei shi ("History of the Northern Dynasties") chapter 97.11b (pp. 3230-31), Zhoushou chapter 50 (p. 918), and Suishu chapter 83 (p. 1854) indicate that in the sixth century when the textual passages were redacted, the origins of the groups which occupied the former territory of the Kusaanas were no longer clearly understood (La Vaissière 2003 [2007]: 120). 
206-7) of the Kușananas or Kushano-Sassanians by adopting the title of Kidāra kușāna șăhi on Brāhmī coin legends. However, the title of Kidāra kușāna șāhi does not necessarily indicate that the Kidāras were related to the Kuṣannas, but ruled the former Kusānạa territory. ${ }^{301}$ Keeping these caveats in mind, Shōshin Kuwayama reconstructs a scenario in which the Kidāras migrated to northwestern Pakistan after gaining control of five kingdoms north of Gandhāra and established a capital at Purușapura (moden Peshawar) based on passages in the Weishu:

The king of Da Yuezhi called Jiduoluo (Kidara), brave and fierce, eventually dispatched his troops southward and invaded North India (present-day Pakistan), crossing the great mountains to subjugate the five kingdoms which were located to the north of Gandhära. ${ }^{302}$

Brief Chinese references to Kidāra rulers coupled with distribution of their coin-types on both sides of the Hindu Kush from northern Gandhāra, Swat and Bannu (in present-day Northwest Pakistan) to Samarkand in ancient Sogdia have resulted in different interpretations of their relationships with regional contemporaries. Since Kidāra coins fit into a continuous series with those issued by their Kushano-Sasanian predecessors, Robert Göbl (1967) views the Kidāras as erstwhile regional allies of the Sasanians against the Alchon Huns. Adopting the perspective of the Chinese accounts, Kuwayama $(1989,1992)$ also holds that the Kidāras were opponents of a subsequent 'wave' of Xiongnu invaders who drove them out of Bactria (which Kuwayama refers to as Tokharistan) and into the northwestern frontiers of South Asia. Frantz Grenet (2002) questions the loyalty of the Kidāras to the Sasanians, since they "cashed in on the military threat they exercised against Iran" (2002: 209) by exacting tribute from Sasanian rulers such as Yazdigird II. While acknowledging a long struggle between

301 Göbl, Robert. 1967. Dokumente zur Geschichte der iranischen Hunnen in Baktrien und Indien. Wiesbaden: Harrassowitz, vol. 2, 53.

302 Translated by Kuwayama, Shoshin. 1992. "The Hephthalites in Tokharistan and Gandhara" (parts 1-2). Lahore Museum Bulletin 5.1-2, 19 (= Kuwayama 1989. "The Hephthalites in Tokharistan and Northwest India." Zinbun, Annals of the Institute for Research in the Humanities, Kyoto University 24, 25-77 and Kuwayama, Shōshin. 2002. Across the Hindukush of the First Millennium: A collection of the papers. Kyoto: Inst. for Research in Humanities, Kyoto Univ.). According to Kuwayama, the five kingdoms to the north of Gandhāra included Yarkand, Tashkurgan, Wakhan, Chitral, and possibly Swat, although Grenet (2002: 207, n. 6) suggests that Kapisa should be added to the list. For a translation of the same passage, see Zürcher 1968: 373 and comments by Zeimal, E.V. 1996. "The Kidarite Kingdom in Central Asia.” In Litvinsky, ed. 1996: 122. 
the Kidāras and Hephthalites (identified with the Alchon Huns) for control of Bactria and Sogdia, Grenet draws attention to evidence for coexistence between the last Kidāras and the first Hephthalites who seem to have been on "hunting terms" (2002: 212) in depictions on two Gandhāran silver bowls found in Swat and in Chilek, north of the Sogdian capital in Samarkand. Grenet surmises that the Kidāras (and the Alchon Huns who later supplanted them) "... sought to control the mountainous nexus of trade routes linking Bactria, India, China, and Sogdiana" (2002: 207). The expansion of the Kidāra and Hephthalite Huns to Sogdia entailed a process of "Bactrianisation" (Grenet 2002: 208) whereby Indian cultural elements (including Buddhist elements) were introduced to some areas of western Central Asia which had not been exposed to the initial phases of long-distance transmission in earlier periods.

By acting as political and cultural mediators between India, Iran, and Central Asia, the Alchon Huns (identifiable with the Indian Hūnas, Chinese Yida or Yada, and Hephthalites in Western historical sources) aided the development of overland trade and expansion of Buddhist networks in the fifth and sixth centuries, despite their exaggerated reputation as oppressive barbarians in Chinese and Sanskrit literary sources. While the Alchon Huns had much in common with the Kidāras (including similar origins in mass migrations from Central Asia to Bactria in the fourth century), they consciously distinguished themselves by abandoning Kuṣanna titles, using Bactrian and Brāhmī instead of Pahlavi on coin and seal legends, and developing distinctive styles of ornamentation and portraiture (particularly their artificially deformed craniums or "steeple heads"). ${ }^{303}$ They played a prominent role in Central Asian geopolitics in the fifth and sixth centuries by engaging in conflicts and enacting alliances with a series of Sasanian rulers (helping Peroz rise to power between 459-484 and sheltering Kawad I between 484-488), and expanding their dominion west to the Merv oasis (probably during the reign of Kavad I) and north to

303 Alram, Michael. 2003 (2007). "Three Hunnic Bullae from Northwest India." Bulletin of the Asia Institute 17, 179; Göbl 1967: 2.232 ff.; Grenet 2002: 210; Callieri, Pierfrancisco. 1997. Seals and Sealings from the North-West of the Indian Subcontinent and Afghanistan (4th Century BC-11th Century AD): Local, Indian, Sasanian, GraecoPersian, Sogdian, Roman. Naples: Istituto universitario orientale, Istituto italiano per l'Africa e l'Oriente, 229-231 (Class IV); Callieri, Pierfrancisco. 1999. "Huns in Afghanistan and the North-west of the Indian Subcontinent: The Glyptic Evidence." In Alram and Klimburg-Salter, eds. 1999: 282-285 (Class D). 
Sogdia (by $509 \mathrm{CE}$ ). ${ }^{304}$ The Alchon Huns began to exchange diplomatic missions with the Chinese court in $457 \mathrm{CE}$ after consolidating their stronghold in eastern Bactria, eventually took control of routes across the Hindu Kush away from the Kidāras, established themselves as overlords of northwestern India, and directly contributed to the downfall of the Guptas, whose position in central India eroded as the Hūnas (whom Skandagupta claimed to have defeated) made significant inroads as far as modern Gujarat and Madhya Pradesh. ${ }^{305}$

The Alchon Huns appear in several inscriptions, including two Buddhist donations that demonstrate religious patronage of monasteries in northern Afghanistan and Pakistan. The recent publication of a Sanskrit inscription on a thin copper scroll belonging to the Schøyen collection provides valuable information about the identities of Alchon Huns who are named in a list of secondary donors who received credit for the erection of a relic stuppa. ${ }^{306}$ If Gudrun Melzer's identification of year 68 as a Laukika era date corresponding to $492 / 3 \mathrm{CE}$ is correct, this inscription supplies a fixed point in the chronology of the Alchon

304 Bivar, ADH. 2004. "Hephthalites." In Encyclopedia Iranica Online, available at http://www.iranica.com/newsite/; Grenet 2002: 212-213, 220-221; Kuwayama 1992: 3 (part 2); La Vaissière, Étienne de. 2005 [2002]. Sogdian Traders: A history. Leiden: Brill, 110-111. Earlier treatments include Christensen, Arthur. 1936. L'Iran sous les Sassanides. Copenhague: Levin \& Munksgaard, 288 ff.; Ghirshman, Roman. 1948. Les Chionites-Hepthalites. Cairo: Institut francais d'archeologie orientale, 82-114 and McGovern, William Montgmery. 1939. The Early Empires of Central Asia: A Study of the Scythians and the Huns and the part they played in world history. Chapel Hill: University of North Carolina Press, 410-419, 454-457.

${ }_{305}$ On the Chinese missions, see Grenet 2002: 210-211; Kuwayama 1992: 4 (part 2); and La Vaissière 2003 (2007): $122 \mathrm{ff}$. Based primarily on numismatic analysis, Göbl 1967: 2.60 ff. identifies approximate dates or "Zeithorizonte" for the initial accession to power ("Annahme der Krone") of the Alchon Huns under Khingila around 450 CE, the conquest of Taxila (ca. 460), and appropriating Indic styles following conflicts with the Guptas in 470/480 (after the death of Skandagupta). For the impact of the Hūnas in Indian history, see Biswas, Atreyi. 1973. The Political History of the Hūnas in India. New Delhi: Munshiram Mahoharlal and Thakur, Upendra. 1967. The Hünas in India. Varanasi: Chowkhamba Sanskrit Series Office, whose synthesis of Indian epigraphic, numismatic, and literary evidence leads him to remark that "the Hūnas also issued forth like the lava of the erupting volcano, blasted the political horizon and soon receded to obscurity" (1967: 70). Tripathi fixes a terminus post quem of 484-5 CE (Mahārāja Maitrigupta's inscription of Gupta year 165 at Eran, edited by Fleet 1888: 88-90), after which "The Hūna hordes now poured into India like swarms of locusts in terrific numbers, and caused the downfall of the Gupta empire" (1942: 280).

${ }^{306}$ Melzer, Gudrun. 2006. "A Copper Scroll Inscription from the Time of the Alchon Huns.” In Buddhist Manuscripts 3, Braarvig, Jens, ed. Oslo: Hermes, 251-278. 
Huns. ${ }^{307}$ Khingila (with the title of mahāṣāhi) and Toramāna (titled devarāja), who were already well-known historical figures (but apparently not father and son, as previously supposed), are listed together with male and female contemporaries: Mehama (like Khingila, a mahạșāhi during whose reign the donation was made), Javūkha (a mahārāja who was the son of Sādavìkha), a queen, and two "mistresses of the great monastery" (mahāvihārasvāminī) named Arccavāmanā and Sāsā. ${ }^{308}$ The primary purpose of this long and ornate inscription is to record the establishment of a reliquary stūpa (tathägatacaityo dhātugarbha) by the 'master of a great monastery' (mahāvihārasvāmin), whose official title of Tälagānika-Devaputrașāhi may indicate that he belonged to the ruling family of the Tālagān region east of Kunduz in northern Afghanistan, which was the geographical heartland of the Alchon Huns. ${ }^{309}$ At the beginning of the inscription, an extensive quotation from a Mahāyāna sūtra (Śrimatībrāhmaṇi pariprcchōa) about the teaching of dependent arising by the Buddha to the Brahmin woman Śrimatī is followed by the introductory verses to Nāgārjuna's Mūlamadhyamakakārika. Melzer (2006: 252) suggests that these citation may indicate the use of Pratityasamutpāda texts in consecration rituals. The invocation of passages from Mahāyāna sūtras and the concluding seven verses composed in classical Sanskrit meters show that monasteries supported by the Alchon Huns in a region "adorned with stūpas resembling a multitude of autumn clouds" (Melzer 2006: 277) were linked to Buddhist scholastic and literary networks.

The Alchon Hun rulers Toramāna and Javūkha are also associated with the donation of a monastery in another Buddhist inscription from Kura in the Salt Range in the western Punjab. ${ }^{310}$ The primary

307 Melzer 2006: 263-4 considers other possibilities, including the Gupta era of 319/20 CE, the Kaniska era (with hundreds omitted) beginning in 127/8 CE, and the era of the Tochi Valley inscriptions of $223 \mathrm{CE}$, but her arguments in favor of the Laukika/Saptarși era (later used by the Palola Șāhis of Gilgit, as discussed in the following subchapter) are convincing.

308 Melzer 2006: 257-262 discusses the historical context of these rulers, whose names and titles are attested in lines 37-39 of the inscription's donative formula (274).

${ }^{309}$ Melzer 2006: 256; Grenet 2002: 210 suggests that eastern Bactria may have been the original base of the Hephthalites, and argues that the later Hephthalites continued to control the area around Surkh Kotal in the Surkh-ab valley on the route between Kunduz and Kabul.

310 Bühler, Georg. 1892. "The New Inscription of Toramana Shaha." Epigraphia Indica 1, 238-241; Sircar 1965: 422-424 (no. 56); Tsukamoto 1996: 976-978. 
donor named Roța-siddhavriddhi, a 'master of the monastery' who was the son of Rota-jayavrddhi, a 'master of many monasteries' (anekaviharrasvāmino), extended the merit of the donation to his own brothers, wives, sisters, sons, and daughters and to all of the queens, princes, and princesses of Mahārāja Toramāṇa and Șāha Javūkha (written Jaūvkha), and expressed the wish that his religious offering (deyadharma) be used for the "attainment of supreme knowledge by all beings." ${ }^{111}$ The names and titles of the Masters of the Monastery, whose "special prosperity" (visessa-vrddhi) was "praised and honored by the lord of Naścīra” (Bühler 1892: 241), corroborates Gregory Schopen's hypothesis that some Buddhist monasteries were privately owned and inherited by prosperous families responsible for their maintenance and supervision. ${ }^{312}$ The last line of the inscription seems to have been intentionally defaced, and the designation of the Mahissāsakas (ācārya mahiśs [äsakānām $]$ ) as recipients of the donation may have been forged. ${ }^{313}$ Although this area has not been carefully surveyed for Buddhist and other archaeological remains, the significance of a monastery located at Kura is probably related to efforts by Hun rulers such as Toramāna (and his son Mihirakula) to maintain access to the "salt road" between Kashmir and the Salt Range. ${ }^{314}$

311 Since the copper scroll inscription (Melzer 2006) clearly differentiates Toramāna from Javūkha, earlier interpretations of Jaūvkha or Jaūvla (as read by Bühler in line 10) as an epithet of Toramāna should be discarded, although the relationship between Javūkha and Toramāna remains unclear. Epigraphic parallels for this donative formula are compiled by Schopen 1979: 5-9 (-2005: 227-231), who argues that this standardized formula does not necessarily indicate Mahāyāna affiliation.

${ }^{312}$ Schopen, Gregory. 1996b. "The lay ownership of monasteries and the role of the monk in Mūlasarvāstivādin monasticism." Journal of the International Association of Buddhist Studies 19.1, 81-126 (= Schopen 2004: 219-259) provides other epigraphic references to the possession of monasteries by lay donors, including vihärasvämins.

${ }^{313}$ Salomon, Richard. 2009. "The Fine Art of Forgery in India." In Écrire et transmettre en Inde Classique. Gérard Colas and Gerdi Gerschheimer, eds. Études Thématiques 23. Paris: École française d'Extrême-Orient, 117-118.

${ }^{314}$ Kuwayama 1992: 6-7 (part 1) connects the importance of the salt trade between Kashmir and the Punjab to the location of the military camp of the Hephthalite ruler near Jhelum. With the assistance of Mohammad Usman, I was able to visit the site ("Kutte Mar") in 1996, and although few surface remains were visible there, numerous other archaeological sites in this part of the Salt Range may belong to this historical period. I have found my unpublished notes ("Ancient Remains in the Salt Range") online at various websites, including: http://www.reference.com/browse/Salt+Range. For references to articles by Michael Meister and Pakistani scholars on Hindu temples from the 6th to 11th centuries in the Salt Range and along the Indus River, see: http:// www.arthistory.upenn.edu/meister/pakistan.html, including Meister, Michael. 2010. Temples of the Indus: Studies in the Hindu Architecture of Ancient Pakistan. Leiden: 
Other epigraphic records of religious donations made by local subordinates of Toramāna demonstrate that Hūna rule in India did not necessarily alter patterns of non-Buddhist patronage. An inscription written on a colossal red sandstone sculpture of the boar avatära of Viṣnu as Varāha at Eran (ancient Airikiṇa) in western Madhya Pradesh clearly indicates that a family of local Brahmin Mahärājas who had ruled under the Guptas until at least 484-5 CE switched their allegiance to Mahārājādhirāja Toramāna within the first year of his Indian conquests. ${ }^{315}$ This expression of obeisance by a local feudatory named Dhanyavișnu who had a Vaiṣnava temple constructed at this site shows that the Hūna domain extended deep into the former territory of the Guptas, but does not really support Upendra Thakur's Hinduization argument that the "culturally weak" victors (the Hūnas) "succumbed to the overwhelming cultural superiority of the vanquished and gradually forgot all about their earlier faiths and beliefs" (1967: 260). The adoption of Vaișnava symbols such as the conch and the appearance of Lakșmī on some coins issued by Toramāna hardly "point to his strong leanings to the Brāhmanic religion" or "mark his emergence as a convert to Hinduism" (Thakur 167: 261), since other issues with fire altars and polyvalent disks (cakras) circulated more widely.

A copper-plate inscription dated in the third year of Toramanna's reign found near Sañjeli in Gujarat records donations of commodities by local and long-distance merchants to a Vaișnava temple of the deity Jayasvāmin. ${ }^{316}$ The temple was built by Virāḍhyika, the queen-mother of Mahārāja Bhūta, a regional overlord (vișayapati) subservient to Toramāna, who is given Gupta imperial titles (Paramabhatțāraka Mahārājādhirāja). As Ranabir Chakravarti notes, donations to this

Brill; Meister, Michael. 1996. "Temples Along the Indus." Expedition 38.3, 41-54; Meister, Michael. 2000b. "Chronology of Temples in the Salt Range, Pakistan." In South Asian Archaeology 1997, ed. Maurizio Taddei and Giuseppe De Marco. Rome: Istituto Italiano per l'Africa e l'Oriente, 2000, 1321-39; and Meister, Michael with Abdur Rehman and Farid Khan. 2000a. "Discovery of a New Temple on the Indus." Expedition 42.1, 37-46.

${ }_{315}$ Fleet 1888: 158-161, no. 36, pl. 23A; Sircar 1965: 420-422, no. 55.

316 Chakravarti, Ranabir. 2008. "Three Copper Plates of the Sixth Century AD: Glimpses of Socio-Economic and Cultural Life in Western India." In South Asian Archaeology 1999, ed. Ellen Raven. Groningen: E. Forsten, 395-399; Mehta, Ramanlal Nagarji, and A.M. Thakkar. 1978. M.S. University Copper Plates of the time of Toramana. Maharaja Sayajirao University archaeology series, no. 14. Vadodara: Dept. of Archaeology \& Ancient History, Faculty of Arts, M.S. University of Baroda; Ramesh, K.V. 1973-5. "Three Early Charters from Sanjeli in Gujarat." Epigraphia Indica 40: $175-186$. 
temple by a mercantile organization (vaniggrāma) of local and longdistance merchants who came from Kanauj, Ujjayinī, and Mathura indicate that the district headquarters of Vadrapāli "...can be viewed as a nodal point in the overland supra-local trade network" (2008: $397)$ and "...combined religio-cultural activities with administrative functions and commercial transactions" (2008: 398). The construction and repair of a sun temple not very far way at Mandasor (Daśapura) in the neighboring region of Mālava by a guild of silk weavers demonstrates that commercial patronage of non-Buddhist temples sustained religious establishments during a period of considerable dynastic flux in the fifth and sixth centuries as the Hūnas contended with Guptas and emergent regional rulers for control of pivotal links between the Indian hinterland and the western coast. ${ }^{317}$

Literary traditions associate Toramānaa's son Mihirakula with religious oppression and the downfall of Hūna power in India, but the evidence from epigraphy and archaeology is ambiguous. In an inscription dated in Mihirakula's fifteenth regnal year, a local donor of a sun temple in Gwalior praises Toramāna and Mihirakula as powerful sovereigns, indicating that the hegemony of the Hunas continued to be acknowledged in areas of north-central India during the earlymid sixth century. ${ }^{318}$ However, the Aulikara rulers of Daśapura in the Mālava region resisted Hūna domination, according to the Rīsthal inscription of Prakāśadharman, who made grandiose claims of defeating Toramāna in battle, using the tusks of his vanquished elephants to make ivory seats for ascetics and dedicating the females of his harem to the temple of Lord Vṛsabhadhvaja (Śiva). ${ }^{319}$ In two sand-

317 Fleet 1888: 79-88, no. 18, pl. 11; Sircar 1965: 299-304, no. 24.

318 Fleet 1888: 161-164, no. 37, pl. 22B; Sircar 1965: 424-426, no. 57. Sircar 1965: 424 gives c. 515-545 CE as an approximate range for Mihirakula's reign, but the claim by the contemporary Aulikara ruler Yaśodharman to have made Mihirakula subservient in his undated Mandasor stone pillar inscriptions (Fleet 1888: 142-150, nos. 33-34, pl. 26B-C; Sircar 1965: 418-420, no. 54) aids in fixing a date for Mihirakula, since another inscription from Mandasor was issued while Yaśodharman was ruling in Mālava year 589, corresponding to 532 CE (Fleet 1888: 150-158, no. 35, pl. 22; Sircar 1965: 411-417, no. 53).

319 Salomon, Richard. 1989. "New Inscriptional Evidence for the History of the Aulikaras of Mandasor." Indo-Iranian Journal 32, 1-36, lines 12-14, vv. 16-18. The Rīsthal inscription is dated in 515 CE (Mālava year 572). Salomon points out that this date does not mark a terminus ante quem for the reign of Toramānā, since "the rhetorical claim of his submission to the Aulikara king proves nothing more than that the two came into conflict, and that Prakāsadharman was not conquered by the Hun" (1989: 27). 
stone pillar inscriptions, ${ }^{320}$ Yaśodharman, who apparently succeeded Prakāśadharman, also claims to have subjugated Mihirakula, "whose forehead was pained through being bent low down by the strength of [Yaśodharman's] arm in obeisance" (Fleet 1888: 148). In this praśasti to Yaśodharman's superiority over Mihirakula, the poet Vāsula remarks that Mihirakula did not render homage to anyone else except Śiva (Sthānu), which leads some historians (such as D.C. Sircar) to suggest that Mihirakula was indeed a Saiva ruler, ${ }^{321}$ although it seems more likely that this convention is more directly related to the importance of Siva as the family deity (istadevatā) of this branch of the Aulikaras.

Mihirakula is depicted as a violent tyrant and as a persecutor of Buddhists in the accounts of Chinese visitors to South Asia, but his rule in Gandhāra, the Punjab, and Kashmir does not appear to have had a negative impact on the growth of Buddhist monasteries. Song Yun, an official Wei envoy, visited the court of the Hephthalite (Heda) ruler in eastern Afghanistan in $519 \mathrm{CE}$ with Huisheng and continued traveling to Swat and Gandhāra in $520 \mathrm{CE}^{322}$ In contrast to the ruler of Swat, who is depicted as a diligent Buddhist vegetarian, Song Yun described the Hephthalite ruler of Gandhāra as a bloodthirsty enemy of Buddhists:

The nature of the king is violent and cruel, very often conducting massacres. He does not believe in the Buddhist faith, but well worships their own heathen gods. As all the inhabitants in the country are Brahmans who respect Buddhism by much reading the sutras, so it is deeply against their wishes that they suddenly have such a king. ${ }^{323}$

In contrast to John Marshall (1951: 1.76-7) and other historians (cited by Kuwayama 2002: 108) who claim that the Hephthalites destroyed Buddhist monasteries in Taxila and elsewhere, Kuwayama emphasizes that "no statement is made in any paragraph proving that the

${ }^{320}$ Fleet 1888: 142-150, nos. 33-34, pl. 26B-C; Sircar 1965: 418-420, no. 54.

${ }^{321}$ Sircar 1965: 419, n. 4 states unequivocally that Mihirakula was a devotee of Śiva. From a numismatic perspective, Grenet observes, “This ruler's own religious sympathies are expressed by the Shivaite trident and bull symbols prominently displayed on his coins" (2002: 211).

${ }_{322}$ There is no specific reference to Mihirakula in Song Yun's Luoyang Qielan ji (translated by Beal 1884: c; Chavannes, Édouard. 1903. "Voyage de Song Yun dans l'Udyāna et le Gandhara (518-522 p.C)." Bulletin de l'École française d'Extrême-Orient 3, 379-440; and Jenner, W.J.F. 1981. Memories of Loyang: Yang Hsüan-chih and the lost capital (493-534). Oxford: Clarendon Press, 265.

${ }^{323}$ Translated by Kuwayama 1992: 4 / 2002: 103, 109. 
Hephthalite king killed Buddhist monks or destroyed Buddhism in Gandhāra" (1992: 4 / 2002: 110). He cautions that Chinese Buddhist monks were especially concerned with "extinction of the True Law" and attributed persecution of Buddhism in Gandhāra to Mihirakula because he was a known historical figure associated with cruelty. ${ }^{324}$ Kuwayama's criticism may be applied to Xuanzang's recapitulation of Mihirakula's attempt to persecute Buddhists when he ruled Sākala (modern Sialkot in the Punjab) "several hundred years ago" (Li 1996: 114). Xuanzang described Mihirakula as "a man of talent and intelligence with a bold and furious nature" (Li 1996: 114) who ordered the destruction of Buddhism and expulsion of monks after a royal servant (rather than a learned monk) was appointed as his Buddhist preceptor. The narrative of Mihirakula's alleged persecution of Buddhism is linked with a story of his capture by King Balāditya of Magadha, whose mother spared Mihirakula from capital punishment. While it is tempting to identify Balāditya with a later Gupta ruler (such as Narasiṃha Balāditya), Balāditya was a common epithet and the story as well as Mihirakula's subsequent campaigns against Gandhāra from a base in Kashmir appear to be anachronistic. Although Mihirakula is described in the Rājataraniginī as a "royal Vetāla (vampire) day and night surrounded by thousands of murdered human beings" (Stein 1900: i.291), a major Buddhist shrine at Harwan was built during this period of Hephthalite rule. ${ }^{325}$ Despite a reputation for cruelty in several literary sources, Mihirakula and his Hūna predecessors may be compared to other "foreign successors [who] legitimated their presence in the same way that the new Indian dynasties clung to some Gupta formulae" (Williams 1982: 102). The Hūnas were probably expelled from central India by the middle of the sixth century, but continued to be perceived as foreign threats to north India from the Punjab, Kashmir and the northwestern frontiers. ${ }^{326}$

\footnotetext{
${ }^{324}$ Kuwayama 2002: 109.

325 Stein remarks that the "legendary anecdotes... reproduce faithfully the popular tradition regarding the king such as had developed in Kaśmir within a century of his death" (1900: 1.78). Kak, Ram Chandra. 1933. Ancient Monuments of Kashmir. London: India Society [reprint, New Delhi: Sagar publications, 1971] and Paul, Pran Gopal. 1986. Early Sculpture of Kashmir. Leiden: Sneldruk Enschede, 39 ff. describe the Buddhist remains at Harwan.

326 Thakur 1967: 140-163 discusses additional Buddhist (Āryamañjuśrīmūlakalpa) and Jain references to the Hūnas and Mihirakula, as well as references to the domain of King Gollas west of the Indus River in the account of Kosmos Indikopleustes (Topographia Christiana), an Alexandrian merchant who visited western India around
} 
In the aftermath of the Hūnas' departure from North India, regional dynasties contended for imperial power, but Hūna rule in pockets of the northwestern frontier continued to have a significant impact on patterns of Buddhist transmission between South Asia and Central Asia. Frantz Grenet argues that "a second Buddhist conquest of Central Asia" during the Hephthalite period was "more far-reaching than the first one in the Kushan period" (2002: 213). In support of this assertion, he refers to Pierfrancisco Callieri's identification of an early sixth-century soapstone statuette of a female playing a harp imported from Gandhara or Kashmir to Merv, where it was deposited in a stūpa with a reliquary, Brāhmī manuscript fragments, and other small figurines. ${ }^{327}$ Although an earlier stüpa may have been established in Merv sometime prior to this period, material evidence of contact between Buddhist cultures in northwestern India and western Central Asia supports Callieri's hypothesis that "the westward expansion of Budhism may therefore have profited from the temporary political subjugation of Margiana" (1996: 399) by the Hephthalites in the fifth and sixth centuries.

The Hephthalites also had an impact on the establishment of a triangular network for long-distance trade dominated by Sogdian merchants. ${ }^{328}$ Over 600 Sogdian graffiti and Bactrian inscriptions in the

530 CE. Schwartzberg, Joseph. 1992 [1978]. Historical Atlas of South Asia. Chicago: University of Chicago Press proposes that the Hūnas were assimilated into Indian society while continuing to wage wars against the Maukharis and other post-Gupta rulers of north India. The Hūnas were stereotyped as enemies to be conquered in the northern direction in epigraphic praśastis and Sanskrit literary epitomes of heroic conquests, according to Pollock 2006: 244 (referring to an inscription written during the reign of Nārāyanapāla, 875-932 CE, extolling anachronistic conquests of Hūnas by his Pāla predecessors).

${ }^{327}$ Pierfrancisco Callieri. 1996. "Hephthalites in Margiana? New Evidence from the Buddhist Relics in Merv." In La Persia e l'Asia centrale da Alessandro al X secolo. Rome: Accademia Nazionale de Lincei, 391-400, figs. 4-5. Frumkin, Grégoire. 1970. Archaeology in Soviet Central Asia. Leiden: Brill, 147-149, figs. 36-38 illustrates and briefly describes the vessel which contained these artifacts. La Vaissière concurs with Callieri in noting that "Buddhism did not spread to Merv before the 4th century, and not during the 2nd century as was previously thought" (2005: 77-78). A similar figure of a woman playing a harp on a chlorite mirror handle from Afghanistan is illustrated and discussed by Ghose, Madhuvanti. 2003 (2007). "The Impact of the Hun Invasions." Bulletin of the Asia Institute 17, 148-9, fig. 4.

${ }^{328}$ Sims-Williams, Nicholas. 1996. “The Sogdian Merchants in India and China." In Cina e Iran: Da Alessandro Magno alla Dinastia Tang. Alfredo Cadonna and Lionello Lanciotti, eds. Firenze, Italy: Leo S. Olschki, 45-67; La Vaissière, Étienne de. 2004. "The rise of Sogdian Merchants and the Role of the Huns: The Historical Importance of the Sogdian Ancient Letters." In The Silk Road: Trade, travel, war and faith. Susan 
Upper Indus valley, particularly at Shatial, indicate that long-distance commerce flourished while the Hephthalites controlled adjoining regions. ${ }^{329}$ Étienne de La Vaissière points out that the frequent appearance of the ethnonym Hun $(x w n)$ in these inscriptions "... is historically inconceivable before a conquest of Sogdiana by the Huns, followed by a period of calm and fusion beween the Sogdian population and the nomadic invaders" (2005: 81-82). ${ }^{330}$ Kuwayama attempts to attribute shifts in trade and pilgrimage routes between South Asia and Central Asia to changes in the political landscape with the rise and fall of the Hephthalites. ${ }^{331}$ Between 550-560 CE, the Hephthalites lost control of western Central Asia and Tokharistan (northern Afghanistan) to Turkish chieftains allied with the Sasanians. ${ }^{332}$ Afterwards, the sphere of Hephthalite rule was confined to the Surkhab valley (the middle course of the Kunduz River in northeastern Afghanistan), although they maintained a network of castles on routes to Bamiyan and an affiliated dynasty of Nezak Shahs held power in the Kabul valley until their defeat by the Arab general Qutaiba in 709-710. ${ }^{333}$ Following the decline of these Hephthalite successors, other local and regional dynasties emerged at important nodes in exchange networks and acted as Buddhist patrons and agents of transmission.

Whitfield, ed. London: British Library, states: “the Huns' invasions in Central Asia gave way to the sole domination of the Sogdians on the caravan routes of Central Asia" (23).

329 Sims-Williams, Nicholas. 1989-1992. Sogdian and other Inscriptions of the Upper Indus I, II. Corpus Inscriptionum Iranicarum v. 3, part 2. London: SOAS; BandiniKönig and Fussman 1997 [MANP 2].

330 "Hun" (Sogdian $x w n$ ) is well attested as a component of names in at least 15 Sogdian inscriptions from the Upper Indus (Sims-Williams 1989-92: 2.80 [glossary]). La Vaissière 2005: 82-83, 87, 108 proposes that an absence of Hun patronyms may indicate that Sogdian merchants ceased to use routes through the Upper Indus when the Hephthalites split the Kidāra kingdom in the first half of the 5th century, but such a short chronology for the Sogdian presence in the Upper Indus region is unlikely.

${ }^{331}$ Kuwayama ties a "drastic change" $(2002: 149,194)$ in the itineraries of Chinese pilgrims and Indian monks from earlier routes through the Karakorum and eastern Hindu Kush to later patterns of travel through the western Hindu Kush (particularly Bamiyan) to the decline of the Hephthalites around $550 \mathrm{CE}$. However, Brāhmī and Proto-Saaradā inscriptions from the Upper Indus demonstrate continuous movement through the 7 th century instead of a disruption in the 6th century. The epigraphic evidence from northern Pakistan is treated in greater detail in Chapter 5: Capillary Routes in the Upper Indus.

${ }^{332}$ Grenet 2002: 213, 221; Kuwayama 2002: 210.

${ }^{333}$ Grenet 2002: 214-218; Kuwayama 2002: 194-199, 211-221. 


\section{Palola Șāhis of Gilgit: Élite Patrons in a Buddhist Enclave}

The Palola Șāhis, a local dynasty of rulers in Gilgit from the late sixth to early eighth century CE, supported the production of Buddhist Sanskrit manuscripts and bronze sculptures at an important administrative and cultural hub in a network of deep valleys in the Karakorum mountains. Manuscript colophons, stone inscriptions, and inscribed bronze sculptures serve as primary sources for Oskar von Hinüber's reconstruction of the chronology and genealogy of this family of Buddhist patrons. ${ }^{334}$ A collection of manuscripts discovered in 1931 west of Gilgit near the village of Naupur in the Kargah valley clearly demonstrates that local Buddhist literary culture flourished during this period. The extensive range of Buddhists texts, including 532 folios of the Mülasarvāstivāda-vinaya, represented in the Gilgit manuscripts seems likely to have belonged to a monastic library, despite arguments to the contrary by Gérard Fussman and Gregory Schopen based on an absence of architectural evidence of monastic structures. ${ }^{335}$ Although absolute dates for the manuscripts can not be determined, Hinüber proposes a terminus ante quem around $630 \mathrm{CE}$ based on the use of the so-called Round Brāhmī script before its replacement by ProtoSāradā. ${ }^{336}$

${ }^{334}$ Hinüber, Oskar von. 2004. Die Palola Șāhis: ihre Steininschriften, Inschriften auf Bronzen, Handschriftenkolophone und Schutzzauber: Materialien zur Geschichte von Gilgit und Chilas. ANP 5. Mainz: Philipp von Zabern.

${ }_{335}$ Fussman, Gérard. 2004. "Dans quel type de bâtiment furent trouvés les manuscrits de Gilgit." Journal Asiatique 292, 101-150 dismisses earlier identifications of the quadrangular tower that contained the manuscrips as a "hollow stūpa" belonging to a royal monastery and instead suggests that it was the dwelling or chapel of an individual eremitic Buddhist teacher (äcärya) or a lineage of teachers. Schopen, Gregory. 2009. "On the Absence of Urtexts and Otiose Ācāryas: Buildings, Books, and Lay Buddhist Ritual at Gilgit." In Colas and Gerschheimer, eds. 2009: 189-219 rejects Fussman's theory that this building served as a residence and chapel for Buddhist monks who performed protective or healing rituals, and instead conjectures "...that it was a kind of sacred workshop, a combination of genizah and scriptorium, where old, unusable, or returned manuscripts (i.e., those with donor colophons or donors' names in them) were kept, along with some master-copies, and where new manuscripts were manufactured and were for sale (i.e., those without donor-colophons or donors' names in them)" (2009: 203). Manuscripts and other materials were excavated by Kaul Shastri, Madhusudan. 1939. "Report on the Gilgit Excavation in 1938." Quarterly Journal of the Mythic Society 30.1, 1-12 + pls. 1407-1434. Another substantial collection of 454 folios of a Sanskrit Dìrghāgama manuscript was reportedly recovered from the site in 1998 (Fussman 2004: 104, n. 8).

${ }^{336}$ In support of ca. $630 \mathrm{CE}$ for the transition from Round Brāhmī to Proto-Saaradā, Hinüber refers to the colophon of a Samghàta-sūtra Proto-Śāradā manuscript dated in year three (samvatsare tritiye 3) of an unspecified era (2004: 25-26, no. 10), which 
Names of early Palola Șāhi rulers, family members, and court officials appear among the lists of donors in colophons of Buddhist manuscripts and dhäranīs (brief textual formulae conferring protection and other benefits). ${ }^{337}$ Three rulers, Vajrāditya-nandin, Vikramādityanandin, and Surendravikramāditya-nandin, are listed along with their wives among the donors of Mahāyāna sūtras in formulae beginning with the phrase: "this religious offering" (deyadharmo yam or devadharmo yam). ${ }^{338}$ Various forms of the name of the Palola Șāhi successor Navasurendrāditya-nandin is written in three Mahāmāyūri fragments and incorporated into copies of the Vimaloṣnișa dhärañ. ${ }^{339}$ As co-donors who received religious merit for their sponsorship of Buddhist manuscripts labeled as "religious offerings" and as donors whose names have been inserted into dhāranīs, Navasurendra, his Palola Șāhi predecessors, their wives, and courtiers participated in the Mahāyāna 'Cult of the Book' in which devotees worship the Buddha's dharmakāya by following exhortations to have many of the sūtras preserved in the Gilgit Sanskrit manuscripts written down.

Navasurendra has full imperial titles in a Sanskrit stone inscription at Hatun in the Ishkoman valley written in the Proto-Śāradā script and dated in year 47 of the Laukika era, corresponding to $671 \mathrm{CE} .{ }^{340}$

would correspond to $627 / 8 \mathrm{CE}$ if calculated according to the same century of the Laukika era as the Hatun inscription of year 47 (671 CE) and the Dainyor inscription of year 62 (687 CE). Hinüber's terminology is adopted here, although "Round Brāhmī" is also referred to as "calligraphic ornate script" or "Gilgit/Bāmiyān Type I," which is distinguished from "Gilgit/Bāmiyān Type II" (Proto-S̄āradā) by changes in writing the character for ya. Sander, Lore. 1989. "Remarks on the Formal Brāhmì of Gilgit, Bāmiyān and Khotan.” In Jettmar, ed. 1989 [ANP 1]: 107-130 comments on the paleography.

${ }_{337}$ Hinüber 2004: 12-27, 77-83 supercedes earlier studies by Hinüber, Oskar von. 1979. Die Erforschung der Gilgit-Handschriften. Nachrichten der Akademie der Wissenschaften in Göttingen. Philologisch-historische Klasse I, no. 12. Göttingen: Vandenhoeck \& Ruprecht, 329-360; Hinüber, Oskar von. 1980. "Die Kolophone der Gilgit-Handschriften.” Studien zur Indologie und Iranistik 5-6, 49-82; Hinüber, Oskar von. 1981. "Namen in Schutzzaubern aus Gilgit." Studien zur Indologie und Iranistik 7, 163-170; and Hinüber, Oskar von. 1983b. "Die Bedeutung des Handschriften-fundes bei Gilgit." In Zeitschrift der Deutschen Morgenländischen Gesellschaft, Supplement 5. XXI Deutscher Orientalistentag, March 24-29, 1980. Wiesbaden: Franz Steiner, $47-66$.

${ }^{338}$ Hinüber 2004: 86-89, nos. 6-9.

339 Kaul Shastri 1939: 8-9; Hinüber 1981: 167; Hinüber 2004: 12-16, 89-90, nos. 1-4; Schopen, Gregory. 1985b. "The Bodhigarbhālañkāralakṣa and Vimaloṣnịṣa Dhāraṇīs in Indian Inscriptions. Two Sources for the Practice of Buddhism in Medieval India." Wiener Zeitschrift für die Kunde Südasiens 29, 141-145 (= Schopen 2005: 332-336).

${ }_{340}$ Chakravarti, N.P. 1953. "Hatun Rock Inscription of Patola-deva." Epigraphia Indica 38: 226-231; Fussman, Gérard. 1993b. "Chilas, Hatun et les bronzes boud- 
The inscription records the excavation of an irrigation canal and the founding of a town by Makara Simgha, an official under the Palola Șāhis who simultaneously held the titles of Great Treasurer, Supreme Minister, Great Chief of the Feudatories, and Military Commander of Gilgit. ${ }^{341}$ Another damaged Sanskrit inscription at Dainyor, near the confluence of the Gilgit and Hunza rivers, with the name of his succesor, Jayamangalavikramāditya-nandin and dated in Laukika era year 62 corresponding to $687 \mathrm{CE}$, may have recorded a land grant, but the details remain uncertain. ${ }^{342}$ The distribution of graffiti inscriptions with names of people with Palola titles or ethnonyms located near the confluence of the Gilgit and Indus rivers at Alam Bridge and at various sites in the Chilas plain of the Upper Indus suggests that the Palola Șâhis exerted considerable influence in the Gilgit valley and surrounding areas of northern Pakistan in the seventh century. ${ }^{343}$

Numerous bronze sculptures inscribed with names of Palola Șāhi queens, kings, and family members with dates in the seventh and eighth century attest to their direct patronage of a local atelier. ${ }^{344}$ The earliest inscriptions record donations of an image of the Buddhist goddess Prajñāpāramitā holding a manuscript (labeled as a Perfection of Wisdom text) by Mangalahamsikā, the Chief Queen of Vajrādityanandin, who belongs to the early seventh century [Fig. 2.4]. ${ }^{345}$ The pedestals

dhiques du Cachemire.” In Jettmar, ed. 1993 [ANP 2]: 4-19; Hinüber 2004: 48-52, no. 22, ills. 18-19; Stein, Marc Aurel. 1944. "Archaeological Notes from the Hindukush Region.” Journal of the Royal Asiatic Society, 5-14. His titles are: Paramabhatțāraka Mahārājādhirāja Parameśvara Pațola Deva Ṣāhi.

${ }^{341}$ These titles contain the earliest reference to the toponym of Gilgit (Giligittā) and Makara Simgha is described as Kãñjuti (Kañudìya), an ethnonym still applied to Burushos, as recognized by Stein 1944: 9 and Fussman 1993b: 14, n. 6. Fussman 1993b: 15 comments that Iranian sarāmgha (Persian sarhanga/ Middle Iranian srhng "hero") demonstrates local adoption of non-Indian titles.

${ }^{342}$ Hinüber 2004: 52-57, no. 23, ills. 20-23.

${ }^{343}$ Hinüber 1989a: 64-65, no. 64, pl. 131; Hinüber 2004: 46-47, 57-62, nos. 18-21, 24-29.

${ }^{344}$ Fussman 1993b: 39-47, pls. 30-31; Hinüber 2004: 28-42, 190, nos. 11-16, Addendum; Hinüber, Oskar von. 2007. "Three New Bronzes from Gilgit. "Annual Report of the International Research Institute for Advanced Buddhology at Soka University 10. 39-44; Hinüber, Oskar von. 2009. "More on Gilgit Bronzes and some Additions to 'Die Palola Șahis.” Annual Report of the International Research Institute for Advanced Buddhology at Soka University 12, 3-6.

${ }^{345}$ Hinüber 2007 has published donative inscriptions of Mangalahamsikā (not included in Hinüber 2004). The copper alloy sculpture $(41 \mathrm{~cm}$ in height) of Prajñāpāramitā is illustrated in Sotheby's auction catalog of Indian and Southeast Asian Art (1 April, 2005: 60, no. 5) and another pedestal inscription recording a donation by Queen Mañgalahasrikā (identical with Mangalahamsikā) together with Śrī Pațoladeva Ṣāha Vajrādityandin, Torabhatārikā, and the treasurer Raṇādhira is in the collection 


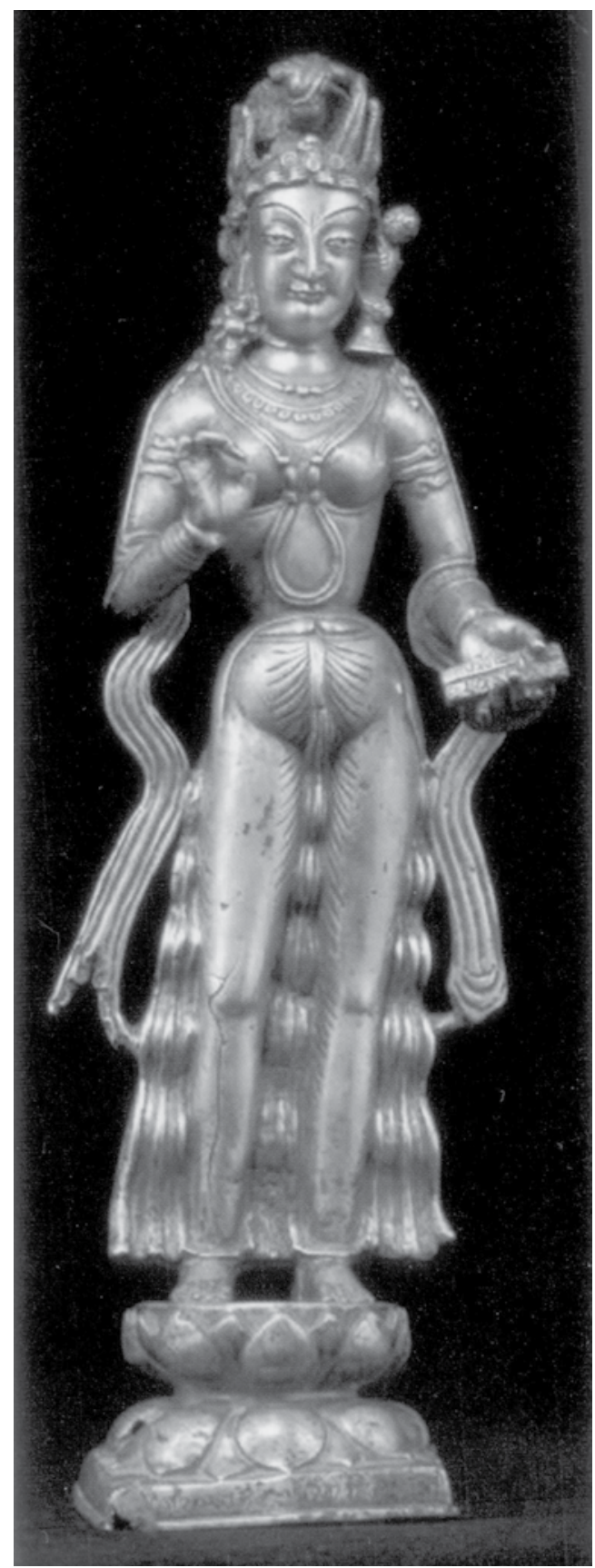

Figure 2.4: Bronze image of Prajñāpāramitā, donated by Mañgalahamsikā, Chief Queen of Vajrādityanandin (Source: Hinüber 2007, plate 1) 
of small bronze images of the Buddha are inscribed with the name of Surendrādityanandin and dated during the reign of Navasurendra in 645-645 CE. ${ }^{346}$ Jayamangalavikramāditya-nandin, the Palola Ṣāhi ruler known from the Dainyor inscription of $687 \mathrm{CE}$, donated a very large bronze sculpture of a seated Buddha dated in 706/7 (Laukika year 82) and another standing Buddha along with his wives, children and courtiers. ${ }^{377}$ His successor, Nandivikramāditya-nandin, donated two exquisite bronze images dated in 714 and 715 CE (Laukika years 90 and 91). ${ }^{348}$ In the earlier image, a jeweled Buddha acknowledges the patronage of this Palola Șāhi ruler by placing one hand on his head while holding a manuscript in the other hand. In the second image, the ruler himself holds a manuscript, perhaps reflecting the role of his family in Buddhist literary production. Another ornate bronze sculpture dated just one week prior to Nandivikramāditya-nandin's inscribed bronze of $714 \mathrm{CE}$ was a gift of the princess Devaśri and her husband, the treasurer Samkarasena, who are depicted in postures of reverence kneeling on lotuses and holding wreaths and incensers at the base of the sculpture. ${ }^{349}$ These dated bronze images donated by Palola Șāhi rulers and their families belong to a larger group of Buddhist bronze images that were produced by a local atelier of artists whose output demonstrates important links between the stylistic heritages of Gandhāra and Swat and traditions of Buddhist art in Kashmir and Tibet.

of the Rubin Museum of Art (New York). Earlier forms of tripartite $y a$ and the later Proto-Sāradā form both appear in the latter inscription. Paramadevi Maṃgalahasirika and Śrī Pațoladeva Șăhi Vajrādityanandi are listed as co-donors in a colophon preserved on a single folio of an unknown text (Hinüber 2004: 24-25, no. 9).

${ }^{346}$ Hinüber 2004: 190, pl. 36 notes that the $14.3 \mathrm{~cm}$ Buddha of Surendrādityanandin was brought from Tibet to the Qing/Manchu court, and is now included in the Collection of the Treasues of the Palace Museum in Beijing, China. The Buddha of Laukika year $20+$ (the inscription on the pedestal is broken after the numeral 20) was donated by Varșa, the son of a treasurer, during the reign of Navasurendra, who is known from dhäranīs and the Hatun inscription of $671 \mathrm{CE}$ (Laukika year 47).

347 Hinüber 2004: 31-38, nos. 12-13. These sculptures now in the Jhokang Palace in Lhasa and Tsaparang were probably brought to Tibet following the downfall of the Palola Șāhis during the period when Gilgit and surrounding valleys in northern Pakistan were occupied by a Tibetan military force between 720-745 CE.

${ }^{348}$ Fussman 1993b: 40-43, pl. 30; Hinüber 2004: 38-42, nos. 14, 16, pls. 5, 7; Paul 1986: 202-218.

${ }_{349}$ Fussman 1993b: 43-7, pl. 31; Hinüber 2004: 39-40, no. 15, pl. 6; Paul 1986: 219-243. 
Shortly after the heyday of Buddhist patronage by the Palola Șāhis in the beginning of the eighth century, their realm became a key battleground in the struggle between the Tibetan and Chinese empires for control of long-distance routes through the high mountain borderlands. After Little Bolor (presumably controlled by the Palola Șāhis) made an alliance with Tang China in 717 CE to deter growing Tibetan influence in the Karakorum and Pamir mountains, Tibetan forces occupied the region in 722 and $737 .{ }^{350}$ Huizhao (Hye Ch'o), a Korean monk who traveled from Kashmir to Bolor, reported that Greater Bolor was controlled by Tibetans and Lesser Bolor was under Chinese dominion before $727 \mathrm{CE}$ :

Greater Bolor was originally the place where the king of Lesser Bolor resided. It was because the Tibetans have come that he fled and shifted his residence to Lesser Bolor. The chiefs and common people remained and did not come. ${ }^{351}$

In $747 \mathrm{CE}$ a Chinese expedition of 10,000 men led by the Korean general Gao Xianzhi crossed the Pamirs and defeated a Tibetan garrison in the Wakhan valley of present-day northeastern Afghanistan. ${ }^{352}$ The Chinese force reached Gilgit through the Yasin valley and subsequently conquered the capital of Baltistan (Great Bolor), located at present-day Katsura near Skardu, in $753 .{ }^{353}$ As a result of the intense conflict between Tibet and China for control of this strategic region in the middle of the eighth century, the Palola Șāhi dynasty disappeared, but religious and cultural exchanges between this region, Central Asia, and the Tibetan plateau are likely to have intensified. ${ }^{354}$

\footnotetext{
${ }^{350}$ Beckwith, Chistopher. 1987. The Tibetan Empire in Central Asia: A History of the Struggle for Great Power among Tibetans, Turks, Arabs, and Chinese during the Early Middle Ages. Princeton: Princeton University Press, 95-116; Hinüber 2004: 97-98; Jettmar, Karl. 1993. "The Patolas, their Governors and their Successors." In Jettmar, ed. 1993 [ANP 2]: 84.

${ }^{351}$ Yang Han-sung, et al. (translator). 1985. The Hye-Ch'o Diary: Memoir of the pilgrimage to the five regions of India. Berkerly: Asian humanities press, 48.

352 Beckwith 1987: 131 ff.; Stein, Marc Aurel. 1922. "A Chinese Expedition across the Pamirs and Hindukush, AD 747." Geographical Journal 59, 122-131.

${ }^{353}$ Stein 1922: 112ff.; Jettmar 1993: 84-91.

${ }_{354}$ Bru-za (or 'Bru-zha/Drusha), corresponding to Little Bo-lu-luo in Chinese sources and Bolor in Arabic and Persian sources, is related to the ethnonym Burusho and the Burushaski language still spoken in Hunza, Nagar, and Yasin (Beckwith 1987: 116, fn. 44). Padmasambhava's links with Swat (Uḍdiyāna) and the foreign origins of the Bon religion in Bru-za (Gilgit region) are probably literary tropes. Nevertheless, Stein, R.A. 1972 [1962]. Tibetan Civilization. Stanford: Stanford University Press, observed: "one cannot but be struck by the stress both Buddhist and Bonpo tradition lays on
} 
Table 2.5: Genealogy and Chronology of the Palola Șāhi Dynasty ${ }^{355}$

\begin{tabular}{ll}
\hline Ruler: & Date: (Laukika year in parentheses) \\
\hline Vajrāditya-nandin & ca. $585-605$ \\
Vikramāditya-nandin & ca. $605-625$ \\
Surendravikramāditya-nandin & ca. $625-644 / 655$ \\
Navasurendrāditya-nandin & ca. $644 / 655-685$ \\
Jayamañgalavikramāditya-nandin (I) & ca. 685-710 \\
Nandivikramāditya-nandin & ca. 710-715 \\
Surendrāditya & ca. $715 / 720-?$ \\
\hline
\end{tabular}

The singular patronage of Buddhist literature and art by the Palola Șāhis in Gilgit contrasts with complex patterns of support for religious institutions affiliated with multiple traditions by their northwestern neighbors and North Indian contemporaries. The survival of at least eight Buddhist monasteries in Gilgit long after the period of the Palola Șāhis is attested in a Khotanese Saka account of an itinerary from the Tarim Basin (via Gilgit) to Kashmir during the reign of Abhimanyugupta (958-972 CE). ${ }^{356}$ However, the number of small monasteries in Gilgit and other places along the route through the Upper Indus region pales in comparison to countless small monasteries and a large monastery with a dharmarāja stüpa and five hundred rock cells in Kashmir. While overlapping with the period of the Palola Șāhis, the Kārkotas (ca. 625-855/6 CE) ruling in Kashmir identified themselves as Vaiṣnavas, but continued to establish and support numerous Buddhist establishments against the backdrop of a flourishing Śaiva literary culture. ${ }^{357}$ For example, in the Räjatarangiṇi, Kalhana refers to King

Bon's foreign origins, which it locates to the south-west of Tibet where India meets the fringes of Iran" (1972: [2]35).

355 Adapted from Hinüber 2004: 99.

356 Bailey, Harold W. 1936. "An Itinerary in Khotanese Śaka." Acta Orientalia 14, 261-262; Hinüber 2004: 74-76; Skjærvø, Prods O. 2002. Khotanese manuscripts from Chinese Turkestan in the British Library: a complete catalogue with texts and translations. Corpus inscriptionum Iranicarum, 6. London: British Library, 524-6 (IOL Khot. S. 21).

${ }^{357}$ The account of the Karkoța dynasty of Kashmir in Kalhana's Räjataranigini (Book 4) is analyzed and translated by Stein 1900: 1.87-97, 120-185. Inden, Ronald. 2000. "Imperial Purānas: Kashmir as a Vaiṣnava Center of the Words." In Inden, Ronald B., et al. 2000. Querying the Medieval: Texts and the history of practices in South Asia. Oxford: Oxford University Press, 29-98 and Sanderson 2009: 60-61, 73, 298-300 offer very different interpretations of the religious history of Kashmir under the Kārkotasas based on the perspectives of their respective foci on Vaiṣnava purānas 
Lalitāditya Muktāpịda's construction of Vaiṣnava temples and Buddhist monasteries, which shared the same complexes at Huskapura and his royal capital at Parihāsapura:

At Huskapura this noble-minded king built the splendid [shrine of Viṣnu] Muktasvāmin and a large Vihära with a Stüpa. (4.18) 358

At Parihāsapura ("which mocked the residence of Indra"):

That king, who was free from passions, built the ever-rich Rajjavihära [royal monastery] with a large quadrangle (catuhśālā), a large Caitya, and a large Jina [Buddha image]. (4.200)

Into the image of Muktākeśava [Viṣnu] he put 84,000 tolakas of gold. (4.201).

And collecting as many thousands of of palas of silver, that pure-minded [king] made the famous [statue of] Parihāsakeśava [Viṣnu image]. (4.202)

With just as many prasthas of copper he made the glorious [statue of] the 'Great Buddha' (Brhadbuddha) which reached up to the sky. (4.203) 359

Although he does not refer to the Palola Șāhis, Kalhana describes relationships between the rulers of Kashmir and the Hindu Șāhis, who ruled from a capital at Udabhāndapura (modern Hund) at an important crossing of the Indus River located to the north of the modern bridge at Attock from 870-871 until 1026 CE. ${ }^{360}$ From their base, the Hindu Șāhis occupied a primary hub on routes between South Asia and Central Asia, maintained fortresses at Barikot and Udegram in the Swat valley, embellished Hindu stone temples in the Salt Range, and presumably supported local Buddhist communities until Bhimapāla, the last Hindu Șāhi, was killed in battle against the Ghaznavids.

(Viṣnudharmottara purāṇa and Nīlamata purāṇa "dialogically" studied by Inden) and Kashmir Śaiva āgama literature (mastered by Sanderson).

${ }_{358}$ Translated by Stein 1900: 1.140, who identifies this monastery with the Wukong's Moung-ti Vihära.

359 Translated by Stein 1900: 1.142, who also provides an archealogical description of the site in an appendix (2.300-303, Note F).

${ }^{360}$ Rājataranginin 5.152-155 (Stein 1900: 1.99-100, 206, 2.336-339 [Note J: The Saahi of Udabhānḍa]. For a detailed historical treatment of the Hindu Saahis, see Rehman, Abdur. 1979. The last two dynasties of the Sahis: an analysis of their history, archaeology, coinage, and palaeography. Islamabad: Centre for the Study of the Civilizations of Central Asia, Quaid-i-Azam University. Thapar 2002: 415-417 and Tripathi 1942: 339-349 provide brief but useful overviews of political history in the Northwest and Kashmir, but do not refer to the Palola Șāhis of Gilgit. 
Several northern Indian contemporaries of the Palola Șāhis remained major patrons of Buddhist institutions, but rulers who identified themselves as Buddhists generally tended to dominate peripheral border regions in the eastern subcontinent. Inscriptions issued by the Maitrakas of Valabhī, who succeeded the Guptas and Hūnas in Gujarat from the sixth to the eighth century, demonstrate complex patterns of religious patronage. The Maitrakas typically referred to themselves as Śaivas (parama-māheśvaras), but approximately a quarter of their inscriptions record donations to Buddhists (including a famous monasic center at Valabhī). ${ }^{361}$ In the account of his visit to Buddhist sites in North India, Xuanzang portrays King Harșavardhana of Kanyākubjā (Kanauj) as a major Buddhist patron and convert who was targeted by "heretics" in a failed assassination attempt, but Harșavardhana's own inscriptions and Bāna's poetic account of his deeds in the Harșacarita depict him as a Saiva. ${ }^{362}$ After his death in 647/8 CE, the Pālas of Bihar and Bengal (ca. 750-1200), who struggled with the Pratihāras of western India and the Rāsțrakūțas of the Deccan for control of the Ganga-Yamuna heartland, explicitly identified themselves as Buddhists (parama-saugata) and were responsible for constructing and expanding many of the great Buddhist monasteries in eastern India. ${ }^{363}$ However, their support for Buddhist institutions hardly precluded patronage of Saiva temples and monasteries, which flourished in a competitive religio-political environment of appropriation and mutual exchange of rituals, iconography, and esoteric ideologies. The Bhaumakaras in Orissa (ca. 736-950) and the Candras in southeast Bengal (ca. 850-1050) followed the Pāla lead in adopting Buddhist epithets while supporting a variety of religious institutions. Buddhist institutions continued to feature prominently in South Asian intellectual and cultural life, particularly in northwestern and northeastern borderland areas which served as bases for expansion across the Himalayas to Tibet and via maritime networks to Southeast Asia.

${ }^{361}$ Sanderson 2009: 72-73; Schmiedchen, Annette. 1993. "Einige Besonderheiten der buddhistischen Schenkungsinschriften unter den Maitrakas." Beiträge des SüdasienInstituts der Humboldt-Universität zu Berlin 1 ("Maitraka-Studien”), 83-108.

${ }^{362} \mathrm{Li}$, Rongxi (trans.). 1996: 141-150.

363 Davidson 2002: 51-62; Sanderson 2009: 80-117; Thapar 2003: 409-411; Tripathi 1942: 354-363. 


\section{Conclusions}

This overview of ancient and early medieval South Asian historical contexts provides a framework for understanding diachronic processes in the formation and expansion of the early Buddhist sangha across regional and cultural horizons, with a general emphasis on the northwestern frontiers of the Indian subcontinent from the time of Aśoka to ca. $750 \mathrm{CE}$. Having completed a whirlwind tour of over a thousand years of South Asian Buddhist history, a pause to reconsider the questions posed at the beginning of this chapter highlights significant patterns.

Passages from inscriptions and texts reveal that much was at stake in shaping Buddhist religious identities through the development of narratives about the historical Buddha (whose parinirvanna probably dates between 400-370 BCE), previous Buddhas, their prior lifetimes, and early followers. By drawing connections between these figures and places in particular chronological frameworks of the past, present and future, hagiographical narratives illustrate core doctrinal beliefs, situate authoritative discourses understood as buddhavacana, establish institutional precedents, justify ritual practices, and promote exchanges of material donations for religious merit. These versions of Buddhist history had important ramifications for building networks of patrons (including but not restricted to powerful rulers and wealthy merchants) and transferring real and imagined religious topologies linked with the Buddha to locations outside of his original homeland, particularly to prosperous cities and agricultural areas.

Interreligious contacts, intrareligious debates, and encounters with exogenous groups played significant roles in shaping and changing Buddhist practices and ideologies. The emergence of Buddhist traditions of renunciation and the elaboration of doctrines of karmic retribution resulted from competitive dialogues with other śramana movements (such as the Jains and Ājivikas) and later Vedic traditions undergoing processes of reformulation. Internal contestation of monastic vinaya regulations and disputed interpretations of which teachings to attribute to the Buddha caused divisions in the saingh (sanghabheda). Alternative goals and practices sytematized (to varying extents) in texts and images associated with "vehicles" (Mahāyāna and Vajrayāna) developed in response to internal and external challenges. Intercultural exchanges with migrating groups, especially in 
the borderland regions of the northwestern Indian subcontinent, had definite impacts on Buddhist material culture, as reflected in syntheses of Indian, Iranian, Hellenistic, and local features in art and architecture. Indo-Iranians, Indo-Greeks, Sakas, Kuṣānasas, and Huns who established various degrees of control over routes connecting Central Asia to South Asia greatly enhanced patterns of cross-cultural contact. Inscriptions recording donations by rulers, family members, and officials associated with these social outsiders demonstrate that their contributions to the expansion and consolidation of Buddhist institutions also aided their assimilation by providing cultural legitimation. Politial and religious dynamics were closely intertwined with social and economic changes, since Buddhist monasteries were often clustered near hubs of commerce and administration on long-distance regional routes which Indian and non-Indian rulers vied to dominate.

Religious economies of exchange based on the awarding of merit for material support of Buddhist monks and nuns had important historical ramifications within and outside of South Asia. The literary legacy of the Mauryan emperor Aśoka as a cakravartin who donated generously and exclusively to the sangha provided an exemplary model for later Buddhist rulers. However, his edicts endorsing (mostly) nonviolent victory by imperial dharma and promoting donations to other śramanas and brahmins were less univalent. Whether or not the Buddhist model of Aśoka was in fact emulated by later rulers (such as Menander and Kanișka), the normative ideal of generous patronage to Buddhist and other religious institutions required basic conditions of commercial or agricultural prosperity, which in turn depended on local, regional, and long-distance economic networks. Changing patterns of patronage and exchange affected the religious economy, since dynastic turmoil, abandonment of old routes and the development of new networks, and a general shift toward permanent endowments by merchant guilds and land grants by rulers had significant implications for the fortunes of Buddhist monasteries. Thus, paths for Buddhist transmission did not remain stable or fixed, but adapted to fluctuating economic and political conditions. 